\author{
UNIVERSIDADE DE SÃO PAULO \\ FACULDADE DE ZOOTECNIA E ENGENHARIA DE ALIMENTOS
}

\title{
GABRIELA LARAALVARENGA
}

\section{Reaproveitamento da Fibra Prensada de Palma para Extração de Óleo rico em Carotenoides utilizando Misturas de Solventes}

\section{Pirassununga \\ 2018}


Reaproveitamento da Fibra Prensada de Palma para Extração de Óleo rico em Carotenoides utilizando Misturas de Solventes

VERSÃO CORRIGIDA

Dissertação apresentada à Faculdade de Zootecnia e Engenharia de Alimentos da Universidade de São Paulo, como parte dos requisitos para a obtenção do Título de Mestre em Ciências da Engenharia de Alimentos.

Área de Concentração: Ciências da Engenharia de Alimentos

Orientadora: Profa. Dra. Christianne Elisabete da Costa Rodrigues

Pirassununga 
Ficha catalográfica elaborada pelo Serviço de Biblioteca e Informação, FZEA/USP, com os dados fornecidos pelo(a) autor(a)

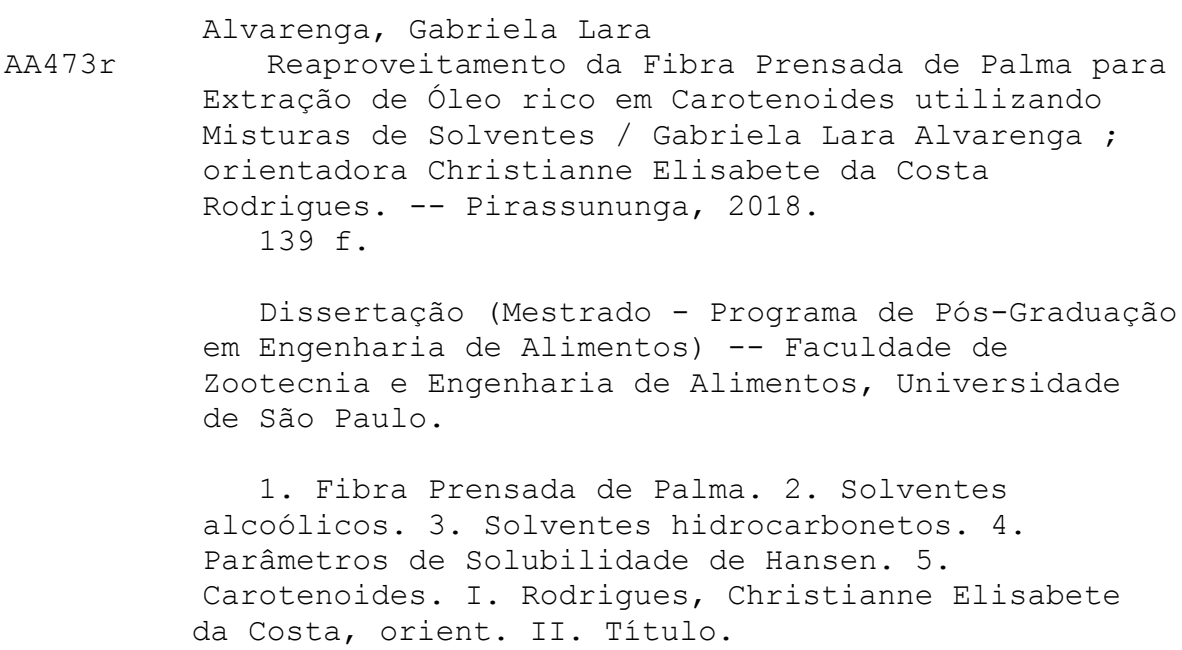

Permitida a cópia total ou parcial deste documento, desde que citada a fonte - o autor 
"Quando morremos, nada pode ser levado conosco, com a exceção das sementes lançadas por nosso trabalho e do nosso conhecimento". Dalai Lama

Dedico este trabalho aos mens queridos pais Edson e Edila, irmãos $\mathfrak{E u i z}_{\text {G }}$ Alberto, Suilherme e Felipe, e a Marcelo. Para Docês, sempre men amor e gralidão! 


\section{AGRADECIMENTOS}

Primeiramente agradeço a Deus por me abençoar em todos os meus caminhos até aqui, por me guiar no bem e por minha saúde.

Pelo incentivo e apoio incondicional dos meus pais, Edson e Edila, dos meus irmãos Luiz Alberto, Guilherme e Felipe, e de todos os meus familiares.

A Marcelo pelos excelentes conselhos, por sua paciência, ombro amigo, pelas palavras de incentivo e coragem e, também, pelo acolhimento e carinho de toda sua linda família.

A minha orientadora Christianne Elisabete da Costa Rodrigues, por sua confiança em meu trabalho e por todos os seus ensinamentos.

A querida Pós-Doutoranda, Maitê Sarria Cuevas por sua ajuda nos experimentos, momentos de descontração, pelos conselhos, paciência e amizade.

A todos do Laboratório de Engenharia de Separações pela atenção, generosidade e disponibilidade em me ajudar sempre que precisei. Agradeço de modo especial, Dayane e Tati, pelos ensinamentos, apoio e amizade.

A amiga Anna Carolina Ercolin por sua amizade, companheirismo e incentivo.

A toda comunidade da FZEA/USP, professores, alunos e funcionários que, contribuíram de alguma forma para a realização deste trabalho.

Aos professores membros da banca examinadora, por aceitarem o convite e pelas importantes contribuições para melhoria deste trabalho.

A CAPES pela concessão da bolsa de mestrado e a FAPESP pelo financiamento através dos Auxílios a Pesquisa (2017/20840-4, 2014/21252-0).

A Profa. Dra. Cynthia Ditchfield e colaboradores do Laboratório de Operações Unitárias e Fenômenos de Transportes (ZEA) e Laboratório de Processos de Engenharia de 
Alimentos (ZEA), pela utilização do agitador de peneiras Tyler, difratômetro a laser e ultrafreezer.

A Profa. Dra. Maria Teresa de Alvarenga Freire e colaboradores do Laboratório de Tecnologia de Sistemas de Embalagem (ZEA), pela utilização do extrator de gordura Sohxlet.

A Profa. Dra. Rosemary Aparecida de Carvalho e colaboradores do Centro Multiusuário de Funcionalidade de Macromoléculas, pela utilização das estufas.

A Profa. Dra. Alessandra Lopes de Oliveira e colaboradores do Laboratório de Tecnologia de Alta Pressão e Produtos Naturais, pelo uso da furadeira elétrica.

Ao Prof. Dr. Luiz Alberto Beraldo de Moraes e colaboradores do Laboratório de Espectrometria de Massas, da Faculdade de Filosofia, Ciências e Letras de Ribeirão Preto (USP), pelas análises em UPLC/MS.

A empresa Agropalma pela doação de fibra prensada de palma, essencial para a realização deste trabalho. 


\section{RESUMO}

ALVARENGA, G. L. Reaproveitamento da Fibra Prensada de Palma para Extração de Óleo rico em Carotenoides utilizando Misturas de Solventes. 2018. $139 \mathrm{f}$. Dissertação (Mestrado) - Faculdade de Zootecnia e Engenharia de Alimentos, Universidade de São Paulo, Pirassununga, 2018.

A extração por solvente é o método mais eficiente para recuperação do óleo residual de fibra prensada de palma (FPP), o qual pode conter um teor de carotenoides até oito vezes superior ao encontrado no óleo de palma bruto. Neste contexto, a escolha de potenciais solventes ou misturas de solventes torna-se essencial, pois elas podem resultar no efeito sinérgico de extração de óleo e carotenoides promovendo uma maior recuperação destes compostos de interesse. Dessa forma, o presente estudo objetivou a utilização de misturas binárias de solventes hidrocarbonetos e alcoólicos, a fim de promover a maior recuperação de um óleo de FPP rico em carotenoides. Para tanto, as composições das misturas compostas por hidrocarboneto (hexano, heptano e ciclohexano) e álcoois de cadeia curta (etanol e isopropanol) foram definidas a partir do cálculo da distância soluto-solvente $(R a)$ entre as misturas de solventes e o soluto $\beta$ caroteno. Os experimentos de extração foram conduzidos a $60 \pm 2^{\circ} \mathrm{C}$ em um intervalo de tempo de 5 horas em extrator em batelada, utilizando os solventes hexano, heptano, ciclohexano, etanol e isopropanol e suas respectivas misturas, e a $55 \pm 3{ }^{\circ} \mathrm{C}$ e um intervalo de tempo de 1 hora e 30 minutos, em coluna empacotada de leito fixo, utilizando hexano, etanol, isopropanol e suas respectivas misturas. Os resultados dos experimentos de extração, em batelada na razão mássica sólido:solvente de 1:7, indicaram que hexano e a mistura compreendida por heptano e isopropanol, extraíram o maior conteúdo de lipídeos, em torno de 80 \% (em massa), enquanto que os demais solventes puros e misturas de solventes permitiram a obtenção de rendimentos de extração de óleo em torno de 70 \% (em massa). Apesar dos solventes ciclohexano e hexano apresentarem a maior extração de carotenoides, o teor deste componente apresentou-se levemente inferior quando foram utilizadas as misturas binárias de solventes. Os maiores rendimentos de extração de óleo de FPP em coluna, na razão mássica sólido:solvente de 1:4, deram-se com o emprego de etanol e da mistura 
compreendida por hexano e isopropanol, em torno de $66 \%$ (em massa), porém o conteúdo de carotenoides obtido foi o mesmo, independentemente do solvente ou misturas de solventes empregadas. O perfil de carotenoides analisados por UPLC/MS apresentou elevado conteúdo de $\beta$-caroteno extraído majoritariamente por hexano, enquanto que o maior conteúdo de a-caroteno foi obtido pela mistura de hexano e etanol, por último, etanol extraiu o maior conteúdo de licopeno. Nesta dissertação não foi observado, de forma expressiva, o sinergismo de extração de óleo de FPP rico em carotenoides com o emprego de misturas de solventes definidas a partir da estimativa dos Parâmetros de Solubilidade de Hansen (PSH) e cálculo da Ra. No entanto, é possível inferir os solventes hidrocarbonetos e suas misturas com os álcoois de cadeia curta, etanol e isopropanol, demonstraram boa habilidade em extrair óleo de FPP rico em carotenoides, mantendo sua composição em ácidos graxos e acidez livre relativamente constantes podendo, assim, serem indicados para operações de extração de óleo de FPP. As misturas de solventes empregadas nos experimentos de extração resultaram em considerável rendimento de óleo de FPP, rico em carotenoides totais mostrando que a substituição parcial de solventes hidrocarbonetos por álcoois de cadeia curta é possível.

Palavras-chave: Etanol, Isopropanol, Hidrocarbonetos, Parâmetros de solubilidade de Hansen, UPLC/MS. 


\begin{abstract}
ALVARENGA, G. L. Reutilization of pressed palm fiber for extraction of oil rich in carotenoids using solvent mixtures. 2018. 139 f. M. Sc. Dissertation - Faculdade de Zootecnia e Engenharia de Alimentos, Universidade de São Paulo, Pirassununga, 2018.
\end{abstract}

Solvent extraction is the most efficient method for recovering palm pressed fiber (PPF) residual oil, which may contain up to eight times the carotenoid content of that found in crude palm oil. In this context, the choice of potential solvents or solvent mixtures becomes essential as they may result in the synergistic effect of extracting oil and carotenoids promoting further recovery of these compounds of interest. Thus, the present study aimed at the use of binary mixtures of hydrocarbon and alcoholic solvents, in order to promote the higher recovery of a carotenoid-rich PPF oil. The compositions of the mixtures composed of hydrocarbons (hexane, heptane, and cyclohexane) and short chain alcohols (ethanol and isopropanol) were defined from the calculation of the solute-solvent distance $(\mathrm{Ra})$ between the solvent mixtures and the solute $\beta$-carotene. The extraction experiments were conducted at $60 \pm 2{ }^{\circ} \mathrm{C}$ during 5 hours in a batch extractor, using the hexane, heptane, cyclohexane, ethanol and isopropanol solvents and their mixtures, and at $55 \pm 3{ }^{\circ} \mathrm{C}$ and a time interval of 1 hour and 30 minutes in a packed bed column using hexane, ethanol, isopropanol and their mixtures. The results of the batch extraction experiments at the solid: solvent mass ratio of $1: 7$ indicated that hexane and the mixture comprised of heptane and isopropanol extracted the highest lipid content, around $80 \%$ (by mass), while that the other pure solvents and solvent mixtures allowed to obtain oil extraction yields around $70 \%$ (by mass). Although the solvents cyclohexane and hexane had the highest extraction of carotenoids, the content of this component was slightly lower when the binary solvent mixtures were used. The higher yields of oil extraction of PPF in the column in the solid: solvent mass ratio of $1: 4$ were given by using ethanol and the mixture comprised of hexane and isopropanol, around $66 \%$ (by mass), but the carotenoids content obtained was the same regardless of the solvent or solvent mixtures employed. The profile of carotenoids analyzed in UPLC/MS showed a high 
content of $\beta$-carotene extracted mainly by hexane, while the highest content of $\alpha$ carotene was obtained by the mixture of hexane and ethanol, finally, ethanol extracted the highest content of lycopene. In this dissertation, the synergism of extraction of PPF oil rich in carotenoids was not observed within the use of solvent mixtures defined from the estimation of Hansen Solubility Parameters (HSP) and calculation of Ra. However, it is possible to infer that the hydrocarbon solvents and their mixtures with the short-chain alcohols, ethanol, and isopropanol, demonstrated good ability to extract of PPF oil rich in carotenoids, maintaining its composition in fatty acids and free acidity constant being indicated for PPF oil extraction operations. The use of the solvent mixtures resulted in a considerable extraction yield of PPF oil, rich in total carotenoids showing that the partial replacement of hydrocarbon solvents by short chain alcohols is possible.

Keywords: Ethanol, Isopropanol, Hydrocarbons, Hansen Solubility Parameters, UPLC/MS. 


\section{LISTA DE FIGURAS}

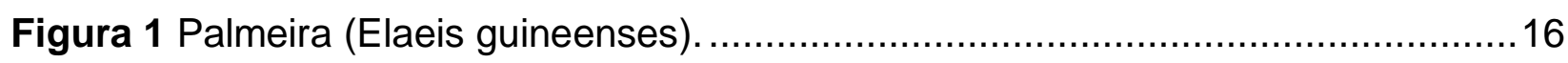

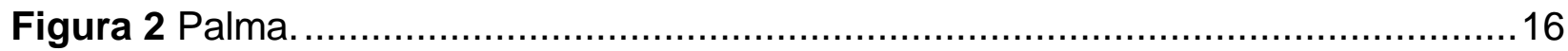

Figura 3 Fibra prensada de palma (A) cedida pela empresa Agropalma para 0 desenvolvimento desta pesquisa; Caroços do fruto da palma (B) . .............................19

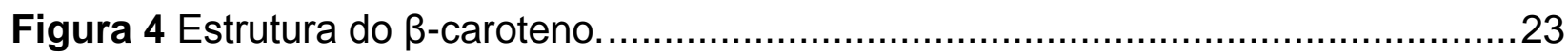

Figura 5 Esfera de solubilidade de Hansen para cálculo da distância soluto-solvente (Ra).

Figura 6 Curva de calibração para $\beta$-caroteno em hexano no comprimento de onda de $450 \mathrm{~nm}$. .50

Figura 7 (a) Extrator utilizado para obtenção de dados de extração sólido-líquido em um estágio. (b) Detalhe interno no extrator. 54

Figura 8 Esquema de coluna de vidro encamisada acoplada a um banho termoestático e a duas bombas peristálticas. .55

Figura 9 Distribuição granulométrica da fibra prensada de palma pelas peneiras Tyler. 63

Figura 10 Distribuição granulométrica da fibra prensada de palma por difração a laser.

Figura 11 Transferência de água (\%) para a fase extrato em função da constante dielétrica. 71

Figura 12 Rendimento relativo (\%) de extração de óleo de FPP utilizando solventes puros e misturas para extrações em batelada. 72

Figura 13 Massas específicas $\left(\mathrm{g} / \mathrm{cm}^{3}\right)$ do hexano e etanol e suas respectivas misturas em função da temperatura.

Figura 14 Massas específicas $\left(\mathrm{g} / \mathrm{cm}^{3}\right)$ do hexano e isopropanol e suas respectivas misturas em função da temperatura. .76

Figura 15 Massas específicas $\left(\mathrm{g} / \mathrm{cm}^{3}\right)$ do ciclohexano e etanol e suas respectivas misturas em função da temperatura.

Figura 16 Massas específicas $\left(\mathrm{g} / \mathrm{cm}^{3}\right)$ do ciclohexano e isopropanol e suas respectivas misturas em função da temperatura. 
Figura 17 Massas específicas $\left(\mathrm{g} / \mathrm{cm}^{3}\right)$ do heptano e etanol e suas respectivas misturas em função da temperatura. .78

Figura 18 Massas específicas $\left(\mathrm{g} / \mathrm{cm}^{3}\right)$ do heptano e isopropanol e suas respectivas misturas em função da temperatura. .78

Figura 19 Viscosidades dinâmicas (mPa.s) do hexano e etanol e suas respectivas misturas em função da temperatura. 79

Figura 20 Viscosidades dinâmicas ( $\mathrm{mPa} . \mathrm{s}$ ) do hexano e isopropanol e suas respectivas misturas em função da temperatura. .79

Figura 21 Viscosidades dinâmicas (mPa.s) do ciclohexano e etanol e suas respectivas misturas em função da temperatura.

Figura 22 Viscosidades dinâmicas (mPa.s) do ciclohexano e isopropanol e suas respectivas misturas em função da temperatura.

Figura 23 Viscosidades dinâmicas (mPa.s) do heptano e etanol e suas respectivas misturas em função da temperatura.

Figura 24 Viscosidades dinâmicas (mPa.s) do heptano e isopropanol e suas respectivas misturas em função da temperatura.

Figura 25 Índice de retenção (kg de solução aderida/kg de sólidos inertes) da fase rafinado de FPP em função da constante dielétrica para diferentes solventes e misturas de solventes.

Figura 26 Cinética de extração de óleo de FPP e de carotenoides (mg $\beta$-caroteno/kg de óleo) utilizando etanol.

Figura 27 Transferência de água (\%) para a fase extrato em função da constante dielétrica. .92

Figura 28 Rendimento relativo (\%) de extração de óleo de FPP utilizando etanol, isopropanol, hexano e as misturas para extração em coluna empacotada.

Figura 29 Índice de retenção ( $\mathrm{kg}$ de solução aderida/kg de sólidos inertes) da fase rafinado de FPP em função da constante dielétrica para diferentes solventes e misturas de solventes. .95

Figura 30 Estrutura molecular de diferentes carotenoides. 102 


\section{LISTA DE TABELAS}

Tabela 1 Conteúdo de carotenoides $(\mathrm{mg} / \mathrm{kg}$ ) presentes em diferentes óleos vegetais. . 23 Tabela 2 Composição (\%) de carotenoides nos óleos bruto e de fibra prensada palma (FPP). .24

Tabela 3 Solubilidade de $\beta$-caroteno em diferentes solventes, a $20{ }^{\circ} \mathrm{C}$. ........................35

Tabela 4 Parâmetros de Hansen para diferentes solventes. 39

Tabela 5 Parâmetros de Hansen para compostos presentes no óleo de canola, para óleo de palma e óleo de coco.

Tabela 6 Composição centesimal da fibra prensada de palma após adequação da umidade.

Tabela 7 Composição centesimal da fibra prensada de palma reportada na literatura. 62 Tabela 8 Valores da distribuição granulométrica da fibra prensada de palma pelas peneiras Tyler.

Tabela 9 Cálculo da distância soluto-solvente $(R a)$ entre o soluto $\beta$-caroteno e diferentes solventes e misturas de solventes, a $25^{\circ} \mathrm{C}$. 65

Tabela 10 Teor de água (\%, em massa) das fases extrato provenientes das extrações sólido-líquido em batelada

Tabela 11 Constantes dielétricas (Di) dos solventes puros e misturas de solventes utilizados nos experimentos de extração sólido-líquido.

Tabela 12 Rendimento relativo (\%) de extração de óleo de fibra prensada de palma em extrator em batelada utilizando solventes puros e misturas de solventes. .73

Tabela 13 Índice de retenção ( $\mathrm{kg}$ de solução aderida/kg de sólidos inertes) para experimentos de extração sólido-líquido em batelada utilizando diferentes solventes de extração.

Tabela 14 Rendimento relativo (\%) de extração de óleo de FPP e teor carotenoides (mg $\beta$-caroteno/kg de óleo) utilizando-se etanol, em função do tempo.

Tabela 15 Teor de água na fase extrato (\%, em massa) para as extrações sólido-líquido em coluna empacotada com solventes alcoólicos, hexano e suas respectivas misturas. 
Tabela 16 Rendimento relativo (\%) de extração de óleo de fibra prensada de palma em coluna empacotada, utilizando solventes alcoólicos, hexano e suas misturas.

Tabela 17 Índice de retenção ( $\mathrm{kg}$ de solução aderida/kg de sólidos inertes) para experimentos de extração sólido-líquido em coluna empacotada utilizando solventes alcoólicos, hexano e suas respectivas misturas.

Tabela 18 Teor de carotenoides (mg $\beta$-caroteno/ $\mathrm{kg}$ de óleo) e acidez livre (\%, em massa) no óleo de fibra prensada de palma obtido das extrações sólido-líquido em batelada e em coluna empacotada utilizando diferentes solventes.

Tabela 19 Conteúdo de carotenoides nos óleos de FPP extraídos com diferentes solventes em coluna empacotada e analisados em UPLC/MS 100

Tabela 20 Composição em ácidos graxos do óleo de FPP extraído com solventes puros e misturas de solventes. 106

Tabela 21 Composições do óleo de FPP extraído com solventes e misturas de solventes. 108 


\section{SUMÁRIO}

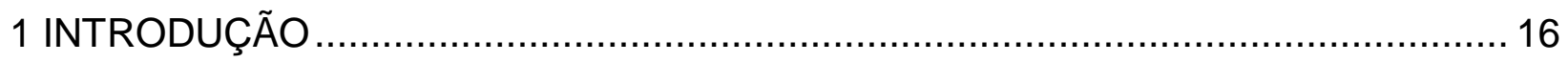

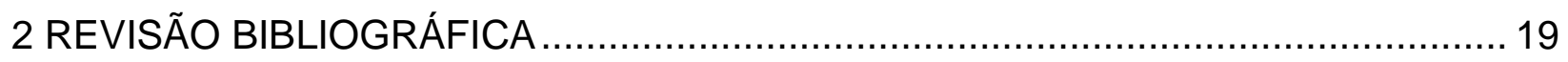

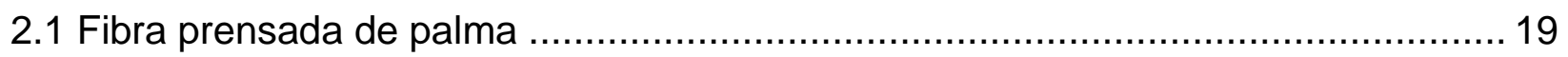

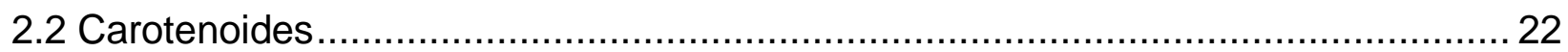

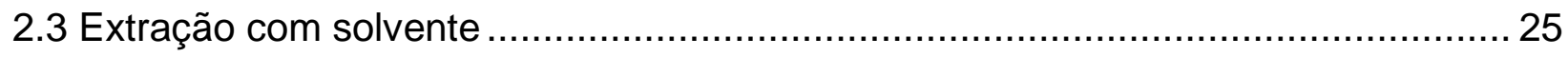

2.4 Parâmetros de Solubilidade de Hansen ............................................................. 35

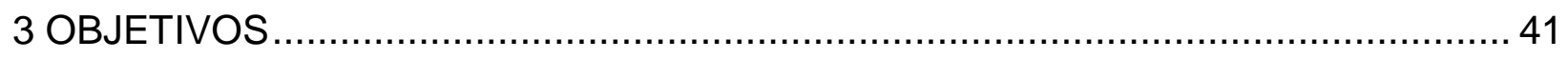

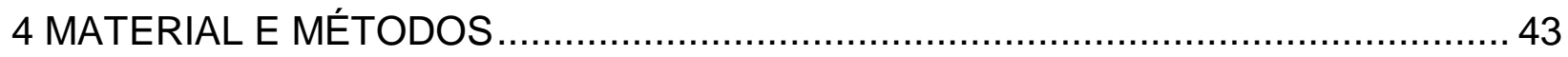

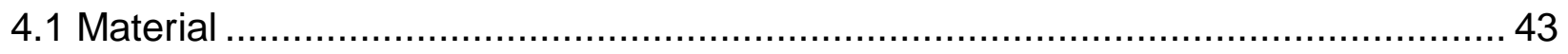

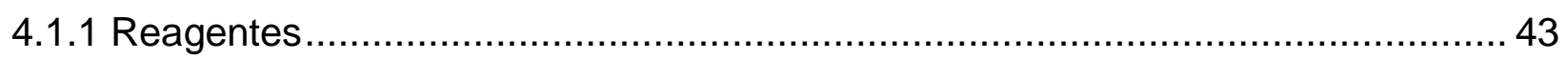

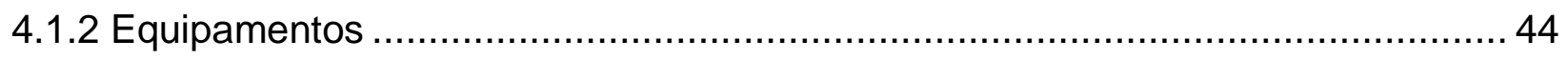

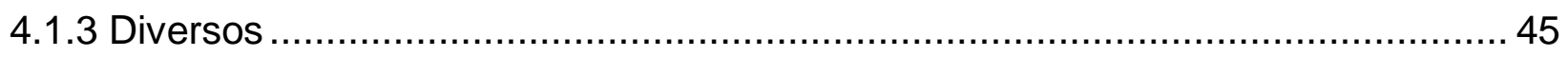

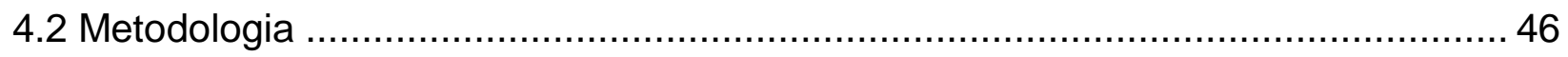

4.2.1 Caracterização da fibra prensada de palma .................................................... 46

4.2.2 Caracterização do óleo de fibra prensada de palma extraído a frio ....................... 48

4.2.3 Determinação experimental de dados de massa específica e viscosidade dos solventes puros e misturas de solventes utilizados nos experimentos de extração de óleo.

4.2.4 Cálculo das constantes dielétricas dos solventes ....utilizados nos experimentos de extração de óleo.

4.2.5 Cálculo da distância soluto-solvente (Ra) para escolha das melhores misturas de

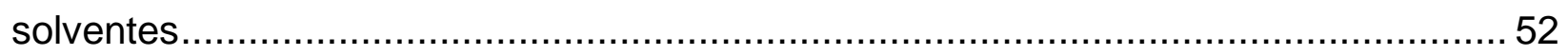

4.2.6 Extração sólido-liquido de óleo de FPP em um estágio em extrator em batelada 53

4.2.7 Extração sólido-líquido de óleo de FPP em coluna empacotada de leito fixo .......54

4.2.8 Análises de caracterização das fases extrato e rafinado .......................................56 


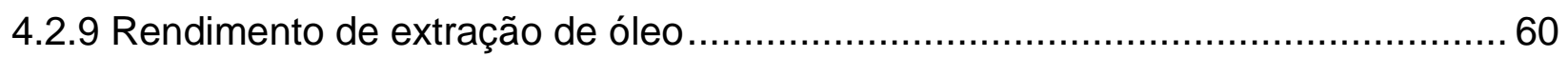

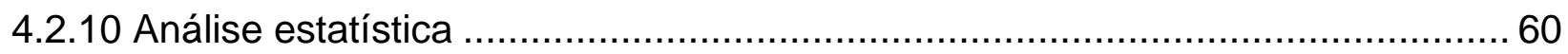

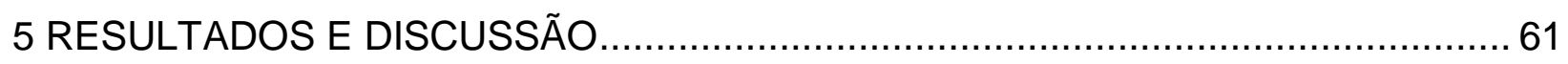

5.1 Caracterização da fibra prensada de palma ....................................................... 61

5.2 Determinação da composição das misturas entre solventes hidrocarbonetos e álcoois a partir do cálculo da distância soluto-solvente $(\mathrm{Ra})$....................................... 65

5.3 Estudo do processo de extração de óleo de FPP em extrator em batelada ............66

5.4 Estudo do processo de extração de óleo de FPP em coluna empacotada de leito

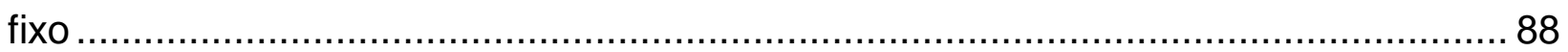

5.5 Caracterização do óleo de fibra prensada de palma obtido com diferentes

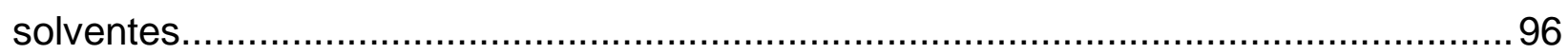

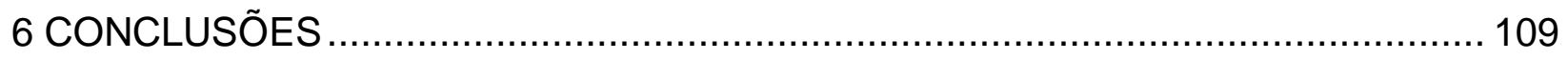

7 SUGESTÕES PARA TRABALHOS FUTUROS ................................................ 111

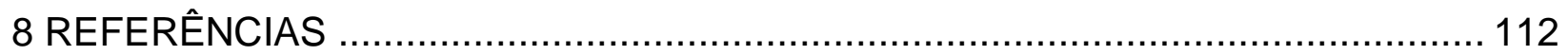

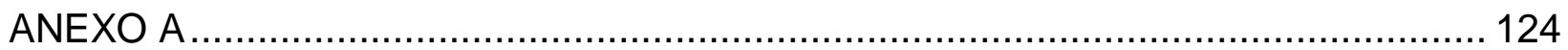

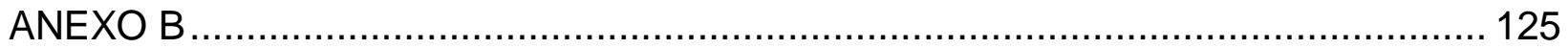

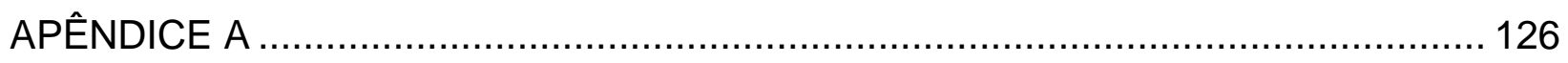

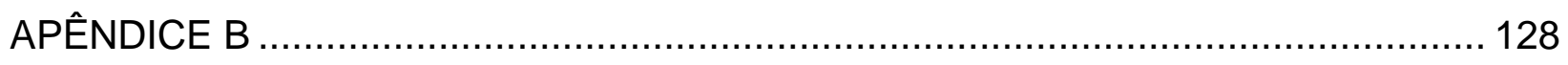

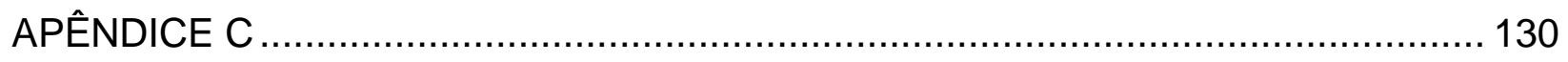

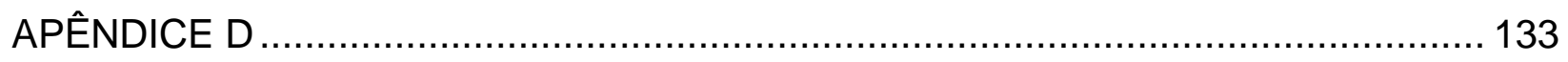

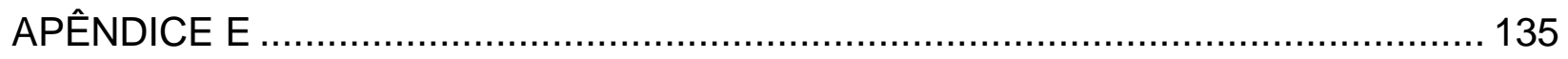

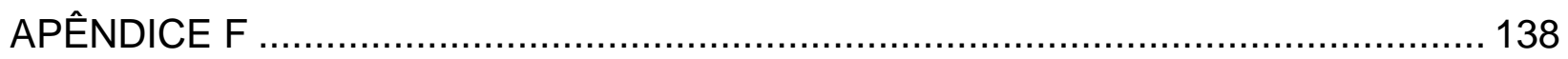




\section{INTRODUÇÃO}

A Palma é o fruto da palmeira (Elaeis guineensis) originária do leste da África (MBA; DUMONT; NGADI, 2015). O óleo extraído da semente da palma é denominado óleo de palmiste, enquanto que o produto resultante da prensagem do mesocarpo da palma é designado óleo de palma. As Figuras 1 e 2 ilustram a foto da palmeira e da palma, respectivamente.

Figura 1 Palmeira (Elaeis guineenses).

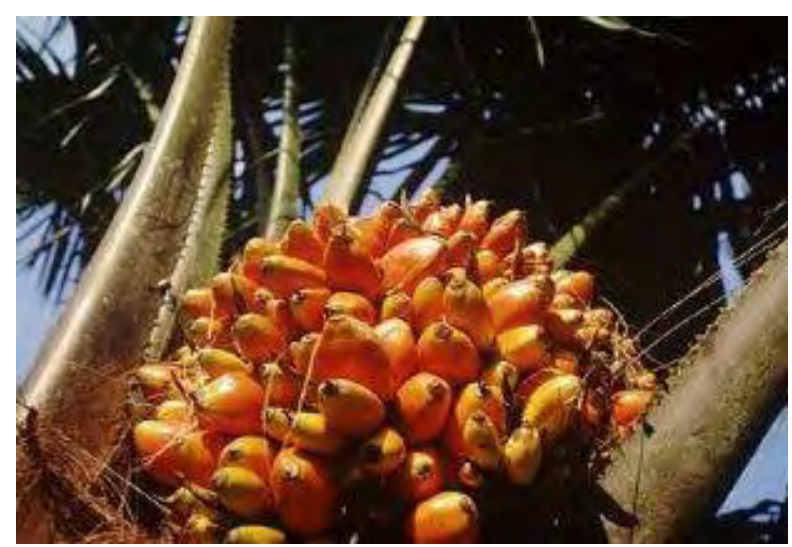

Fonte: Globo Rural online. Disponível em: <http://revistagloborural.globo.com/Revista/Common/0,,EMl188680-18078,00GOVERNO+DIVULGA+ZONEAMENTO+AGRICOLA+DA+PALMA+DE+OLEO.html>. Acesso em: 10 out. 2017.

Figura 2 Palma.

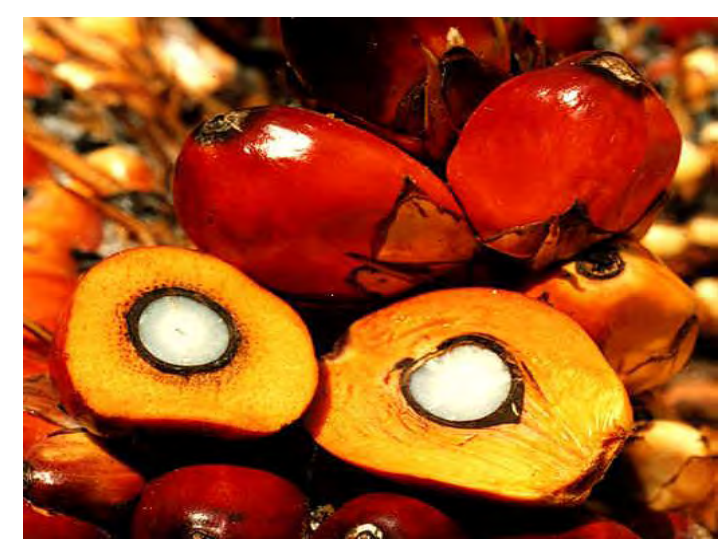

Fonte: COLLARES, D. Disponível em: <https://ainfo.cnptia.embrapa.br/digital/bitstream/item/44255/1/RevistaAgroenergia-2-1417.pdf >. Acesso em: 10 out. 2017.

O óleo de palma é o óleo vegetal mais produzido no mundo. Sua produção global 
até novembro de 2017 foi de aproximadamente 66,87 milhões de toneladas, sendo que deste total, Indonésia e Malásia detêm cerca de $85 \%$ da produção mundial, com produção de 36 e 21 milhões de toneladas de óleo de palma, respectivamente (USDA, 2017). Menor produção deste óleo dá-se pela Tailândia (2,2 milhões de toneladas), Colômbia (1,320 milhões de toneladas) e Nigéria (970 mil toneladas) (USDA, 2017). No Brasil a produção de óleo de palma em 2017 foi de aproximadamente 410 mil toneladas (INDEX MUNDI, 2018).

A produtividade do óleo de palma por hectare plantado chega a ser até 10 vezes superior à dos óleos de soja, colza e girassol (BERGER, 2001) e devido a sua composição balanceada entre ácido palmítico (44 \%) e ácido oleico (39 \%) (BASIRON, 2005) é possível seu fracionamento em frações líquidas e sólidas (LAI, 2005) que favorece suas aplicações como óleo de cozinha e de fritura industrial, na formulação de margarina, biscoitos, sorvetes, maioneses, shortenings, vanaspati (produto gorduroso alternativo à manteiga animal usado na Índia), manteiga de cacau equivalente, uso em saladas, entre outros (GUNSTONE, 2011).

No processamento do fruto da palma, após a prensagem do material, permanece no equipamento um subproduto denominado fibra prensada de palma (FPP) com teor de lipídeos de 5 a $6 \%$, em massa (base seca) (CHOO et al., 1996).

De fato, se for considerada a proporção de FPP gerada em relação à quantidade de óleo produzido, de 1:1,45, reportada por Harrison, Nur e Choo (2013), podemos fazer uma projeção da geração de FPP e, consequentemente, do óleo de palma que não foi recuperado deste material. Se no ano de 2017 66,87 milhões de toneladas de óleo de palma foram produzidos no mundo, pode-se estimar que 46,12 milhões de toneladas de FPP foram geradas, o que representa para as indústrias processadoras de óleos vegetais a perda de cerca de 2,77 milhões de toneladas de óleo de palma, somente naquele ano.

Geralmente a FPP é submetida à queima na caldeira da própria empresa produtora de óleo de palma, no entanto, este subproduto destaca-se por seu elevado teor de carotenoides, vitamina $\mathrm{E}$ (tocoferóis e tocotrienóis) e esteróis ( $\mathrm{CHOO}$ et al., 1996). 
O óleo rico em carotenoides contido na FPP pode, de fato, se tornar uma matéria-prima destinada à indústria de alimentos, de cosméticos e farmacêutica desde que este seja extraído de forma adequada. Desta forma, este material deixaria de ser um simples subproduto destinado a queima em caldeiras.

Neste contexto, este trabalho sugere o estudo da viabilidade técnica do emprego de solventes menos agressivos, etanol e isopropanol, e hidrocarbonetos menos tóxicos (ciclohexano e heptano) como substitutos do hexano no processo de extração do óleo de FPP rico em carotenoides.

As vantagens da utilização dos solventes alcoólicos, etanol e isopropanol, para substituição total ou parcial do hexano, solvente tradicionalmente utilizado pela indústria de óleos vegetais, relaciona-se ao fato destes álcoois de cadeia curta possuírem menor grau de inflamabilidade, não gerarem resíduos tóxicos, serem seguros para a saúde humana e produzidos por via biotecnológica (RODRIGUES; OLIVEIRA, 2010; TIR et al., 2012). No caso dos hidrocarbonetos alternativos ao hexano, a vantagem reside no ato destes apresentarem potencial capacidade de extração de compostos lipídicos e minoritários, porém menor grau de toxicidade que o hexano (ALFONSI et al., 2008; FDA, 2012; GALVIN; BOND,1999; WAN et al., 1995a).

A finalidade de usar solventes mistos, a partir da mistura de solventes com diferentes polaridades, é obter a solubilização de compostos de interesse que possuam afinidade química com a mistura de solventes utilizada favorecendo, assim, sua extração. Para tanto, é importante que haja sinergismo entre as misturas de solventes polares e hidrocarbonetos na extração de óleo de palma e carotenoides. Este possível sinergismo foi avaliado a partir do cálculo dos parâmetros de solubilidade de Hansen e distância soluto-solvente $(\mathrm{Ra})$. 


\section{REVISÃO BIBLIOGRÁFICA}

\subsection{Fibra prensada de palma}

A fibra prensada de palma fresca apresenta um teor de umidade de aproximadamente 30 \% (FRANÇA, 1999). Já a análise da sua composição química (\% em base seca) feita por Cardenas-Toro et al. (2014) resultou em $30 \pm 2 \%$ de lignina insolúvel e 1,1 $\pm 0,1 \%$ de lignina solúvel, $6,3 \pm 0,1 \%$ de proteínas, 3,1 $\pm 0,1 \%$ de cinzas, 6,4 \pm 0,4\% de extrativos em água, 3,7 \pm 0,2 \% de extrativos em etanol e, 48,6 $\%$ de carboidratos, obtidos por diferença. A Figura 3 apresenta as fotos da FPP seca (Figura 3A) e os caroços separados manualmente (Figura 3B), material gentilmente doado pela empresa Agropalma ao Laboratório de Engenharia de Separações da FZEA/USP.

Figura 3 Fibra prensada de palma (A) cedida pela empresa Agropalma para o desenvolvimento desta pesquisa; Caroços do fruto da palma (B).

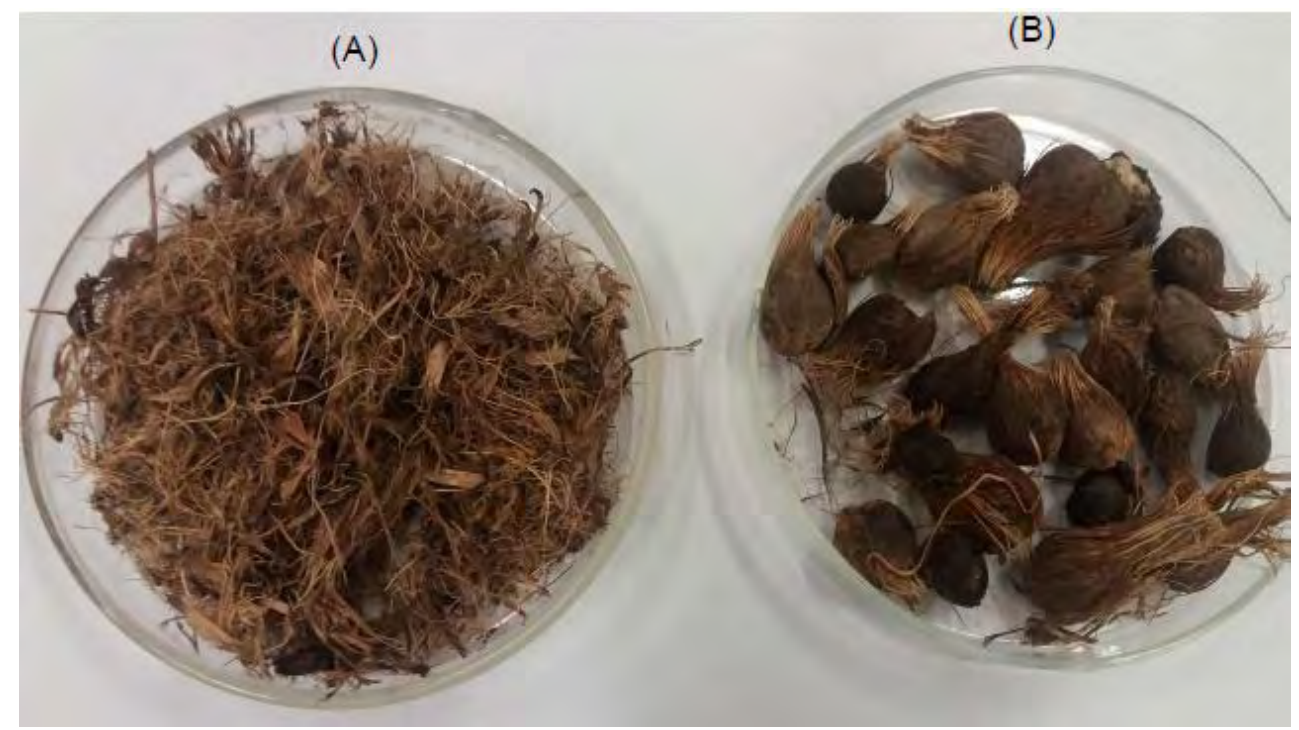

Fonte: Própria autoria.

Além da queima como combustível em caldeiras, a FPP foi utilizada na fabricação de pães a fim de enriquecer o seu conteúdo de fibras (KAMARUN ZAMAN, 2008). 
Ainda, Prado et al. (2014) recuperaram 11,9 \% de açúcares redutores e 2,4 \% de monossacarídeos da fibra prensada de palma através da hidrólise com água em estado subcrítico para produção de açúcares fermentescíveis.

Porém, o grande destaque deste subproduto é devido ao seu conteúdo de óleo residual constituído por carotenoides, vitamina E, esteróis, esqualeno, co-enzima Q10 e compostos fenólicos (CHOO et al., 1996; LAU et al., 2006; TAN et al., 2007).

Segundo Kemper (2005), para obtenção do óleo de palma bruto, o fruto da palma é submetido à esterilização, limpeza e aquecimento. Posteriormente, é realizada a etapa de prensagem mecânica em prensa do tipo parafuso. Este equipamento mecânico possui um parafuso, o qual empurra o fruto da palma sobre as paredes do equipamento, conferindo pressão. Como o tambor que circunda a prensa é perfurado ao longo do comprimento do equipamento, com o aumento da pressão interna, o ar é primeiramente removido e, após, é promovida a saída de óleo pelo tambor. O óleo extraído é coletado na parte inferior do equipamento e o material sólido resultante é descarregado no final da prensa (KEMPER, 2005). Vale ressaltar que para a obtenção do óleo de palma a prensagem do fruto deve ocorrer de modo que remova óleo do fruto sem extrair o óleo das sementes, sendo este denominado de óleo de palmiste (HAMM; HAMILTON, 2000). Ao final, este processo de extração é capaz de reduzir a quantidade de óleo do fruto da palma a $5 \%$, com um percentual de quebra das sementes menor que $15 \%$ (HAMM; HAMILTON, 2000).

De fato, o processo de prensagem para a extração de óleo do mesocarpo é convencionalmente feito uma única vez, logo pode ocorrer uma perda de óleo considerável (CHOO et al., 1996). Ademais, como citado anteriormente, um teor de óleo residual de cerca de 5 a $6 \%$, em massa (\% em base seca) é encontrado na fibra prensada de palma (CHOO et al.,1996).

Enquanto o óleo bruto de palma, extraído do mesocarpo, possui cerca de 500 a 700 $\mathrm{mg}$ de carotenoides/kg de óleo (BASIRON, 2005), uma quantidade oito vezes superior de carotenoides pode ser recuperada do óleo da fibra prensada de palma, o qual pode apresentar de 4.000 a $5.500 \mathrm{mg}$ de carotenoides/ kg de óleo (CHOO et al., 1996).

No contexto da obtenção de um óleo rico em compostos minoritários, diversos autores utilizaram diferentes técnicas para extração do óleo residual da FPP. 
Lau et al. (2006) extraíram óleo da fibra prensada de palma utilizando $\mathrm{CO}_{2}$ supercrítico e o método tradicional Soxhlet utilizando o solvente hexano e concluíram que a qualidade do óleo extraído da fibra prensada fresca é superior ao da fibra seca a $60^{\circ} \mathrm{C}$ por 8 horas. Em relação à estabilidade oxidativa, os autores observaram que 0 óleo obtido por Soxhlet apresentou maior estabilidade, possivelmente por este conter maior teor de fosfolipídeos. Estes compostos atuam como uma barreira à oxidação, porém aumentam os custos no refino. O conteúdo de triacilgliceróis extraídos pelos dois métodos variou entre 93,52 a 94,30\% e o teor de carotenoides no óleo extraído da fibra seca utilizando dióxido de carbono supercrítico e hexano $(4.000-4.600 \mathrm{mg} / \mathrm{kg})$ foi superior ao valor obtido a partir da fibra fresca $(2900-3500 \mathrm{mg} / \mathrm{kg})$.

Em trabalho subsequente, Lau et al. (2008), a partir da extração com $\mathrm{CO}_{2}$ supercrítico com aumento progressivo da pressão (10 a $30 \mathrm{MPa}$ ) e temperatura de 40 ${ }^{\circ} \mathrm{C}$, promoveram a recuperação de $90 \%$ de carotenoides, vitamina $\mathrm{E}$, esteróis e esqualeno da FPP, além do aumento do rendimento de extração do óleo residual. Conteúdos expressivos de vitamina E (2188-3650 mg/kg), esteróis $(4742-5347 \mathrm{mg} / \mathrm{kg})$ e esqualeno (3847-9690 mg/kg) foram extraídos a $10 \mathrm{MPa}$, enquanto que a maior extração de carotenoides (2894-5498 mg/kg) deu-se à pressão de $30 \mathrm{MPa}$. Ademais, os valores apresentados foram superiores aos valores obtidos por Lau et al. (2006) com extração utilizando hexano.

Outro método de extração dos componentes da FPP foi utilizado por Sanagi et al. (2005) a partir da extração com líquido pressurizado (PLE) utilizando hexano como solvente. O método demonstrou boa eficiência na extração de óleo residual $(99,2 \%)$ e na recuperação de isômeros de vitamina $E(3,7-4,0 \mathrm{mg} / \mathrm{mL}$ de óleo residual) e de $\beta$ caroteno (3,3 - 3,5 $\mathrm{mg} / \mathrm{mL}$ de óleo residual), sendo estes resultados semelhantes ou maiores do que os obtidos através da extração por Soxhlet utilizando hexano ou clorofórmio.

Choo et al. (1996) obtiveram um óleo rico em carotenoides $(4.000$ a $5.500 \mathrm{mg} / \mathrm{kg}$ de óleo residual), tocoferóis/tocotrienóis (1.200 a $2.400 \mathrm{mg} / \mathrm{kg}$ de óleo residual) e esteróis (7.050-8.490 mg/kg de óleo residual) utilizando hexano como solvente. Neste mesmo estudo, a extração com clorofórmio recuperou 3.800 a 5.300 mg 
carotenoides $/ \mathrm{kg}$ de óleo residual, 1.650 a $2.600 \mathrm{mg}$ tocoferóis/tocotrienóis $/ \mathrm{kg}$ óleo residual e, por fim, 6.906 a 8.200 mg esteróis/ kg óleo residual.

Aspectos relacionados ao composto de interesse desta dissertação, os carotenoides, serão discutidos no item a seguir.

\subsection{Carotenoides}

Carotenoides são sintetizados por todos os organismos fotossintéticos incluindo plantas superiores, algas, fito plâncton e bactérias foto trópicas e, também, por algumas outras bactérias, leveduras e fungos (LIAAEN-JENSEN, 2004). Estes pigmentos lipossolúveis com cores variando entre vermelho, alaranjado e amarelo estão presentes em penas de flamingos, gema de ovo e no exoesqueleto de invertebrados devido a ingestão de alimentos ricos em carotenos (SCHIEBER; CARLE, 2005).

Existem aproximadamente 600 tipos de carotenoides e, dentre eles, $\beta$-caroteno, $\alpha$-caroteno, $\beta$-criptoxantina, licopeno, luteína e zeaxantina são os mais estudados em termos de sua relação com a melhoria da saúde humana (RODRIGUEZ-AMAYA; RODRIGUEZ; AMAYA-FARFAN, 2006).

Apenas 50 tipos de carotenoides atuam como precursores da vitamina $A$, enquanto que o $\beta$-caroteno apresenta a maior atividade pró-vitamínica A (SCHIEBER; CARLE, 2005).

O $\beta$-caroteno é um composto orgânico tetraterpênico, contendo 40 átomos de carbono (LIAAEN-JENSEN, 2004) e sua estrutura pode ser observada na Figura 4.

De fato, em óleos vegetais, a quantidade de carotenoides encontrada é baixa, excetuando-se os óleos brutos de palma (500 - $700 \mathrm{mg} / \mathrm{kg}$ ), buriti $(1890 \pm 112 \mathrm{mg} / \mathrm{kg}$ ), tucumã $(1222,33 \pm 34,50 \mathrm{mg} / \mathrm{kg})$ e da fibra prensada de palma $(4520-5600 \mathrm{mg} / \mathrm{kg})$ que apresentam conteúdo expressivo de carotenoides (CHOO et al., 1996; FERREIRA et al., 2011; SANTOS; ALVES; ROCA, 2015; SILVA et al., 2009). A Tabela 1 apresenta o conteúdo de carotenoides em diferentes óleos vegetais. 
Figura 4 Estrutura do $\beta$-caroteno.

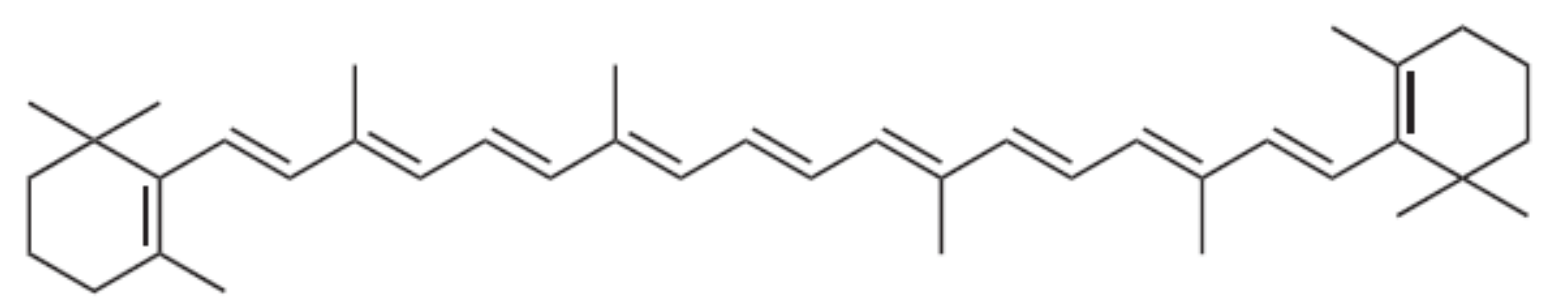

Fonte: Adaptado de SHAHIDI, F.; ZHONG, Y. Antioxidants: Regulatory Status. In: F. Shahidi. 6 ed th. Bailey's Industrial Oil and Fat Products. New Jersey: John Wiley and Sons, p. 99-189, 2005.

Tabela 1 Conteúdo de carotenoides $(\mathrm{mg} / \mathrm{kg})$ presentes em diferentes óleos vegetais.

\begin{tabular}{|c|c|}
\hline Óleo Vegetal & Carotenoides (mg/kg) \\
\hline Óleo de Maracujá Refinado ${ }^{a}$ & $2,3 \pm 0,2$ \\
\hline Óleo de Buriti Brutob & $1890 \pm 112$ \\
\hline Óleo de Pequi Bruto ${ }^{a}$ & $275 \pm 3$ \\
\hline Óleo de Babaçu Bruto ${ }^{a}$ & $19,8 \pm 0,5$ \\
\hline Óleo de Canola Bruto ${ }^{c}$ & 130 \\
\hline Óleo de Farelo de Milho Bruto ${ }^{d}$ & 80 \\
\hline Óleo de Bacaba Bruto ${ }^{e}$ & $14 \pm 1$ \\
\hline Óleo de Inajá Bruto ${ }^{e}$ & $85 \pm 6$ \\
\hline Óleo de Pupunha Bruto ${ }^{e}$ & $357 \pm 4$ \\
\hline Óleo de Tucumã Bruto ${ }^{e}$ & $1222 \pm 35$ \\
\hline Óleo de Palma Bruto ${ }^{\dagger}$ & $500-700$ \\
\hline Óleo de Fibra Prensada de Palma ${ }^{f}$ & $4520-5600$ \\
\hline $\begin{array}{l}\text { Fonte: }{ }^{a} \text { FERREIRA, B. S.; DE ALMEIDA, C. G } \\
\text { GRAZUL, R. M.; LE HYARIC, M. Comparative pr } \\
\text { Molecules, v. 16, n. 7, p. 5874-5885, } 2011 . \\
\text { bSILVA, S. M.; SAMPAIO, K. A.; TAHAM, T.; ROC } \\
\text { Extracted from Buriti Fruit (Mauritiaflexuosa) Gr } \\
\text { Chemists' Society, v. 86, p. 611-616, } 2009 \\
{ }^{\circ} \text { PRZYBYLSKI, R.; MAG, T.; ESKIN, N. A. M.; } \\
\text { Industrial Oil and Fat Products. New Jersey: Jo } \\
\text { d } \text { NAVARRO, S. L. B.; CAPELLINI, M. C.; ARACA } \\
\text { Corn germ-bran oils extracted with alcoholic sol } \\
\text { solubility of defatted meal. Food and Bioproduct } \\
\text { e'SANTOS, M. F. G.; ALVES, R. E.; ROCA, M. } \\
\text { Brazilian Amazon. Grasas Y Aceites. v.66, n. 3, } \\
{ }^{f} \text { CHOO, Y.-M.; YAP, S.-C.; OOI, C.-K.; MA, A.-N. } \\
\text { A Good Source of Natural Carotenoids, Vitamin E } \\
\text { 73, n. 5, p. 599-602, 1996. }\end{array}$ & $\begin{array}{l}\text { EIDA, A.; DINIZ, C. G.; DA SILVA, V. L.; } \\
\text { s obtained by different extraction methods. } \\
\text { MEIRELES, A. J. A. Characterization of Oil } \\
\text { zon Region. Journal of the American Oil } \\
\text { ola Oil. } 6 \text { th ed. In: F. Shahidi. Bailey's } \\
\text { v.2, p. } 70 \text {. } \\
\text { C. E. C. Food and Bioproducts Processing } \\
\text { oil composition and evaluation of protein } \\
\text { 185-194, } 2016 \text {. } \\
\text { in oils obtained from palm fruits from the } \\
\\
\text { f. Recovered Oil from Palm-Pressed Fiber: } \\
\text { f the American Oil Chemists' Society. v. }\end{array}$ \\
\hline
\end{tabular}


O perfil de carotenoides presentes no óleo residual da fibra prensada de palma foi determinado por Choo et al. (1996) como pode ser observado na Tabela 2.

A Tabela 2 destaca o conteúdo superior de carotenoides totais do óleo da fibra prensada em comparação com o óleo bruto de palma. Ademais, percebe-se que no óleo bruto de palma, cerca de $90 \%$ dos carotenos são constituídos por $\alpha$ e $\beta$-caroteno, enquanto que na fibra prensada de palma esses compostos representam apenas $50 \%$ do total de carotenos, possuindo ainda frações de licopeno (14,13\%), fitoeno (11,87\%), $\zeta$-caroteno $(7,56 \%)$, $\delta$-caroteno e outros compostos minoritários.

Tabela 2 Composição (\%) de carotenoides nos óleos bruto e de fibra prensada palma (FPP).

\begin{tabular}{|c|c|c|}
\hline & Óleo de FPP & Óleo de Palma Tenera ${ }^{a}$ \\
\hline Fitoeno & 11,87 & 1,27 \\
\hline Fitoflueno & 0,40 & 0,06 \\
\hline$\beta$-Caroteno & 30,95 & 56,02 \\
\hline$\alpha$-Caroteno & 19,45 & 35,06 \\
\hline Cis- $\alpha-C a r o t e n o$ & 1,17 & 2,49 \\
\hline$\zeta$-Caroteno ${ }^{b}$ & 7,56 & 0,69 \\
\hline$\delta$-Caroteno & 6,94 & 0,83 \\
\hline Y-Caroteno & 2,70 & 0,33 \\
\hline Neusporeno $^{c}$ & 3,38 & 0,29 \\
\hline$\beta$-Zeacaroteno & 0,37 & 0,74 \\
\hline$\alpha$-Zeacaroteno & Traços & 0,23 \\
\hline Licopeno $^{d}$ & 14,13 & 1,30 \\
\hline Total $(\mathbf{m g} / \mathbf{k g})$ & $4520-5600$ & $500-700$ \\
\hline
\end{tabular}

a Óleo de Palma Bruto Comercial da Malásia.

b Isômeros 1-trans e 2-cis.

${ }^{\mathrm{c}}$ Isômeros 1-trans e 1-cis.

'Isômeros 1-trans e 3-cis.

Fonte: CHOO, Y.-M.; YAP, S.-C.; OOI, C.-K.; MA, A.-N.; GOH, S.-H.; ONG, A.- H. Recovered Oil from Palm-Pressed Fiber: A Good Source of Natural Carotenoids, Vitamin E, and Sterols. Journal of the American Oil Chemists' Society, v. 73, n. 5, p. 599-602, 1996.

As potenciais utilizações dos carotenoides relacionam-se à sua adição como pigmentos em margarinas, sorvetes, queijos, bebidas, molhos, carnes e produtos de confeitaria e padaria (BELITZ; GROSCH; SCHIEBERLE, 2004). Particularmente, os carotenoides extraídos do óleo bruto de palma são adicionados como pigmento na formulação de margarinas (BELITZ; GROSCH; SCHIEBERLE, 2004). 
Uma vez que o $\beta$-caroteno exibe a maior atividade pró-vitamínica A (SCHIEBER; CARLE, 2005), ou seja, possui a capacidade de se transformar em retinol (a vitamina $A$ ativa no organismo), sua ingestão é essencial para promover a saúde do globo ocular, desenvolvimento e manutenção do tecido epitelial e crescimento dos ossos (RIBEIRO; SERAVALLI, 2004). Ademais, diversos estudos relacionam a ingestão de fontes ricas em $\beta$-caroteno com propriedades anticancerígenas (CARPENTER, 2006; PALOZZA et al., 2008; SLATTERY et al., 2000) e capacidade anti-ateroesclerose, pois é capaz de diminuir os níveis de gorduras nas artérias (GAZIANO et al., 1990).

Ainda, o licopeno possui atividade antioxidante pois atua como supressor do oxigênio singlete (DI MASCIO; KAISER; SIES, 1989; DI MASCIO; MURPHY; SIES, 1991).

Nesse sentido, considerando o expressivo conteúdo destes pigmentos presentes no óleo residual extraído da fibra prensada de palma e suas potenciais aplicações, se recuperado de maneira adequada este óleo rico em carotenoides pode ser destinado ao uso na indústria farmacêutica, alimentícia e de cosméticos, contribuindo para a formulação de produtos com elevado valor agregado. Assim, o processo de extração por solvente do óleo residual da fibra prensada de palma será abordado a seguir.

\subsection{Extração com solvente}

Os óleos vegetais podem ser obtidos por prensagem do material sólido, extração com solvente ou através da combinação destes dois métodos.

Segundo Anderson (2005), a extração por solvente é indicada para materiais oleaginosos que contêm até $20 \%$ de lipídeos e este processo possui a finalidade de separar o óleo bruto dos carboidratos e proteínas que compõem o material oleaginoso para que, ao final, o produto vegetal apresente o menor teor de óleo bruto possível.

De acordo com Williams (2005), a operação de transferência de massa denominada extração com solvente envolve as operações de lixiviação, lavagem, difusão e diálise. Em relação a etapa de diálise, pode-se considerar que a estrutura do sólido funciona como uma barreira seletiva, em forma de membrana, através da qual os solutos, notadamente os triacilgliceróis, se difundem, como resultado de um gradiente 
de concentração (QUEIROZ, COLLINS e JARDIM, 2001). Do processo de extração as duas fases, sólida e líquida, as quais possuem um gradiente de concentração, se enriquecem e empobrecem continuamente, com os componentes denominados solúveis e extraíveis até atingir um estado de equilíbrio.

No contexto da obtenção de compostos lipídicos de matrizes oleaginosas, tradicionalmente, o hexano (ou hexana) é o solvente mais empregado na prática industrial. Este solvente é um derivado de petróleo contendo uma mistura de isômeros de hexano (faixa de ebulição de 65 a $71^{\circ} \mathrm{C}$ ). A hexana contém cerca de 45 a $70 \%$ de n-hexano, além de metil-ciclopentano, 3-metil-pentano, 2-metil-pentano e ciclohexano (WAKELYN; WAN, 2006; HAMMOND et al., 2005).

Sua ampla utilização baseia-se em suas características que incluem a alta capacidade de solubilização de óleo, baixa perda na etapa de recuperação do solvente, alta estabilidade, baixa corrosão e baixo custo (JOHNSON; LUSAS, 1983). No entanto, o uso deste solvente apresenta algumas desvantagens devido sua alta inflamabilidade, elevado poder poluidor e a possível escassez devido sua origem fóssil (JOHNSON; LUSAS, 1983; OLIVEIRA; GARAVAZO; RODRIGUES, 2012a). Além disso, o composto n-hexano é considerado uma neurotoxina nos Estados Unidos da América com toxicidade comprovada quando presente em elevadas concentrações (HAMMOND et al., 2005). Devido a estas razões, existe hoje um considerável interesse da comunidade científica em propor solventes alternativos substitutos ao hexano que possam ser utilizados pela indústria processadora de óleos vegetais.

A busca por solventes alternativos mais vantajosos é o desejo da maioria das indústrias e, em linhas gerais, algumas das características desejáveis de um solvente podem ser citadas (BOSS, 2000; JOHNSON e LUSAS, 1983; REGITANO-D'ARCE, 1985; THOMAS, 2003):

1- Apresentar alta estabilidade quando exposto ao calor, umidade e luz;

2- Possuir baixa inflamabilidade;

3- Possuir alta seletividade a triacilgliceróis deixando no farelo desengordurado fosfolipídeos, ácidos graxos livres e ceras que reduzem a estabilidade do óleo, contribuindo, assim, para o posterior processo de refino; 
4- Deve ser inerte ao contato com equipamentos;

5- Apresentar elevada pureza para padronizar as características operacionais;

6- Possuir alta solubilidade à elevada temperatura e baixa solubilidade a temperatura ambiente, favorecendo a separação das fases oleosa e solvente, o que implicará na condução das operações de evaporação ou destilação sob condições mais brandas;

7- Deve apresentar fácil armazenamento e transporte;

8- Ser facilmente recuperado no processo;

9- Ser amplamente disponível no mercado;

10- Não deixar odores no óleo ou farelo após a extração;

11- Apresentar custo acessível.

Logo, potenciais substitutos ao hexano vêm sendo analisados por pesquisadores, tais como o etanol, o isopropanol, a água, o limoneno, as cetonas, entre outros (FRANCO et al., 2007; HANMOUNGJAl et al., 2000; HU et al., 1996; MAMIDIPALLY; LIU, 2004).

Alguns solventes alternativos polares apresentam, de modo geral, algumas vantagens na extração de óleos vegetais, sendo capazes de adentrar à parede celular permitindo a extração mais completa de seu conteúdo (TIR et al., 2012). Dessa forma, principalmente etanol e isopropanol, devido sua polaridade, extraem elevados teores de compostos que não são acilgliceróis, como fosfolipídeos e material insaponificável (NAGENDRA PRASAD et al., 2011).

Estudos sobre substituição do hexano pelo etanol resultaram em acréscimo no rendimento de extração de pigmentos, açúcares e fosfolipídeos em comparação com o hexano, porém com capacidade similar de extração de óleo (REGITANO-D'ARCE; ASSIS; LIMA, 1994).

Sawada et al. (2014) avaliaram o efeito de diferentes condições de extração alcoólica no rendimento de óleo de soja, composição em ácidos graxos e solubilidade proteica da farinha desengordurada. Os resultados indicaram a supressão na extração de óleo com o aumento do teor de água do solvente, ao passo que um aumento na temperatura favoreceu a extração do óleo. A composição química e perfil de ácidos 
graxos dos óleos obtidos através da extração com etanol apresentaram valores típicos de óleo de soja, independentemente das condições de extração, evidenciando a viabilidade técnica do emprego do etanol no processo de extração do óleo de soja. No caso da oleaginosa soja vale ressaltar que o principal produto de processamento é o farelo desengordurado, devido ao alto teor proteico, sendo o óleo extraído um subproduto. Este cenário, portanto, é diferente do cenário da indústria produtora de óleo de palma.

Rodrigues, Aracava e Abreu (2010) avaliaram os parâmetros termodinâmicos do processo de extração de óleo de soja utilizando etanol como solvente. No estudo, os níveis de hidratação do etanol variaram entre 0 e $13 \%$ (em massa) utilizando uma ampla faixa de temperatura $\left(50\right.$ a $100^{\circ} \mathrm{C}$ ) e razão entre solvente e sólido de 2,8 (em massa). Neste estudo, os solventes com baixo conteúdo de água foram mais efetivos na extração de óleo devido ao aumento na variação da entropia que resultou em variação de energia de Gibbs negativa o que denota que o processo de extração é viável e espontâneo nestas condições. No entanto, com o aumento da temperatura houve melhora no rendimento de extração de óleo, independentemente do conteúdo de água do solvente.

Rodrigues e Oliveira (2010) estudaram a influência da hidratação do solvente e temperatura em trabalho sobre extração de óleo de farelo de arroz utilizando o solvente etanol. Os teores de água adicionados ao solvente variaram entre 2,94 e 20,01\% (em massa), a proporção entre solvente e sólido utilizada foi de 3:1 (em massa) e as temperaturas de processo variaram entre 40 a $60{ }^{\circ} \mathrm{C}$. Segundo os autores, a maximização da extração de substâncias solúveis e gama-orizanol, com minimização do índice de retenção de solução na fase rafinado e extração de ácidos graxos livres extraídos, foi possível com a adição de menores teores de água ao solvente, independentemente da temperatura, sendo a faixa ótima de hidratação do solvente variando entre 5 e $10 \%$ (em massa).

Em estudo posterior, Oliveira et al. (2012b) investigaram o efeito do uso de diferentes condições de operação tais como o conteúdo de água adicionado ao etanol (0 a $24 \%$, em massa), temperatura (de 40 a $60{ }^{\circ} \mathrm{C}$ ), proporção solvente e farelo de arroz (2,5:1 a 4,5:1, em massa) e velocidade de agitação (100 a 250 rpm) na obtenção 
de óleo de farelo de arroz e compostos nutracêuticos. Segundo os autores, o maior rendimento de extração de óleo de farelo de arroz (99,9\% do conteúdo total de óleo) foi obtido com nível de hidratação do solvente de $6 \%$ (em massa) a $82{ }^{\circ} \mathrm{C}$, utilizando a proporção de solvente e sólido de 4:1 (em massa) e velocidade de agitação de 137,5 rpm. Ademais, os óleos obtidos apresentaram composição em ácidos graxos típica de óleo de farelo de arroz, enquanto os conteúdos em $\mathrm{mg}$ de tocóis (tocoferóis e tocotrienóis) e mg de orizanol por $\mathrm{kg}$ de óleo de farelo de arroz, variaram entre $123 \mathrm{a}$ 271 e 1527 a 4164 , respectivamente.

Bessa (2016) verificou a possibilidade de se utilizar etanol absoluto na produção de biodiesel, sendo um dos seus focos principais a extração do óleo de farelo de arroz. Nesse estudo, foi executada uma sequência de extrações em batelada simulando o processo contínuo de extração contracorrente em 5 estágios, sendo a proporção solvente e farelo utilizada na extração de $3: 1$ (em massa), a $100{ }^{\circ} \mathrm{C}$. $O$ processo de extração utilizando etanol como solvente foi possível e favorecido pelo aumento da temperatura. O óleo de farelo de arroz obtido apresentou caracterização físico-química dentro dos padrões exigidos pela legislação, com exceção do alto teor de ácidos graxos livres. Apesar do número de estágios ideais requeridos para a extração de óleo de farelo de arroz utilizando etanol ser superior ao número necessário quando se utiliza hexano como solvente, o teor de óleo residual no rafinado final foi menor do que 0,5\% (em massa) o que comprova a efetividade do processo de extração sólido-líquido utilizando etanol.

As vantagens da utilização do etanol como solvente substituto ao hexano estão atreladas a larga produção deste solvente no Brasil, o que favorece a obtenção deste solvente a baixos custos (RITTNER, 1992).

O estudo comparativo entre o emprego do isopropanol e do hexano na extração do óleo de farelo de arroz demonstrou a habilidade superior do isopropanol em extrair vitamina E, porém, com eficiência similar na extração de orizanol (HU et al., 1996).

Tir et al. (2012) investigaram o efeito da polaridade de diferentes solventes nas propriedades do óleo extraído de sementes de gergelim. As extrações foram realizadas em extrator do tipo Soxhlet utilizando os seguintes solventes: hexano, etanol, acetona, diclorometano, isopropanol, mistura de hexano/isopropanol e mistura de 
clorofórmio/metanol. Os autores consideraram o isopropanol um solvente eficaz e vantajoso para a extração de óleo de gergelim. Adicionalmente, o isopropanol apresentou teores superiores de extração de tocoferóis totais, seguido pelo etanol, sendo superiores ao hexano e demais solventes.

A extração simultânea de óleo, ácidos clorogênicos e tocoferóis da torta de sementes de girassol foi estudada por Scharlack (2015) utilizando os solventes etanol e isopropanol, absolutos e azeotrópicos, em temperaturas variando entre 60 e $90{ }^{\circ} \mathrm{C}$. A autora reporta que a hidratação do solvente afetou negativamente o rendimento de extração de óleo sendo este acrescido com o aumento da temperatura. De maneira geral, a extração sequencial em 3 estágios, a $90^{\circ} \mathrm{C}$, possibilitou a obtenção de óleos vegetais com composição típica de óleo de girassol para todos os solventes utilizados, porém a obtenção de óleos com maior conteúdo de ácidos clorogênicos foi resultante da utilização do etanol azeotrópico, enquanto que conteúdo de a-tocoferol foi superior utilizando isopropanol (absoluto e azeotrópico) e etanol absoluto. Ademais, a maior polaridade dos solventes alcoólicos hidratados resultou em maior extração de fosfolipídeos (SCHARLACK et al., 2017).

Os solventes alcoólicos etanol e isopropanol, hidratados ou não, foram utilizados em estudo realizado por Navarro et al. (2016) para extração do óleo de uma mistura de farelo e gérmen de milho, em temperaturas variando entre 50 a $80^{\circ} \mathrm{C}$. Neste trabalho, a utilização de etanol aquoso na extração sequencial, a $70{ }^{\circ} \mathrm{C}$ resultou em um rendimento de extração de óleo de aproximadamente $70 \%$, enquanto os demais solventes resultaram em valores superiores de rendimento, de até $90 \%$. Em relação aos compostos minoritários extraídos, o isopropanol absoluto apresentou melhor desempenho de extração de carotenoides de $373 \mathrm{mg} / \mathrm{kg}$, já o etanol azeotrópico extraiu maior teor de tocoferóis e tocotrienóis de 449 e $195 \mathrm{mg} / \mathrm{kg}$, respectivamente.

Ademais, a utilização de etanol como solvente na extração de óleo de torta de macadâmia nas temperaturas de 50 a $80^{\circ} \mathrm{C}$ resultou em maiores valores de índice de retenção que o isopropanol absoluto, decorrente de sua maior polaridade (NAVARRO, 2016).

Em outro estudo sobre o reaproveitamento do óleo de borra de café, a partir da extração com solventes alcoólicos, etanol e isopropanol, Toda (2016) reporta uma maior 
obtenção de ácidos clorogênios a $60{ }^{\circ} \mathrm{C}$ com o uso de etanol hidratado, porém os solventes hidratados apresentaram pior desempenho de extração de óleo quando comparados aos solventes absolutos nas temperaturas de 60 a $90^{\circ} \mathrm{C}$.

Capellini et al. (2017) estudaram as características do óleo e da fração proteica provenientes do processo de extração a partir do farelo de arroz utilizando como solventes o etanol e o isopropanol, com ou sem hidratação. Neste estudo, foi obtido em média, um rendimento de extração de $16 \mathrm{~g}$ de óleo por $100 \mathrm{~g}$ de farelo de arroz, a $80^{\circ} \mathrm{C}$ com a utilização dos solventes etanol e isopropanol em grau absoluto e ainda, obtenção superior de $\mathrm{y}$-orizanol (1,53 $\pm 0,02 \%$ ), utilizando etanol hidratado a $60{ }^{\circ} \mathrm{C}$, quando comparado a extração industrial com hexano. Adicionalmente, um maior conteúdo de fosfolipídeos foi extraído com a utilização de etanol hidratado a $60{ }^{\circ} \mathrm{C}$ devido a sua maior polaridade.

Ainda, foi possível recuperar cerca de $98 \%$ de óleo de torta de sementes de gergelim, rico em sesamina, em apenas um estágio, a $90{ }^{\circ} \mathrm{C}$, no estudo feito por Capellini (2017) com o emprego de etanol e isopropanol em grau absoluto. Destaca-se ainda, o expressivo conteúdo de tocoferóis, em torno de $177 \mathrm{mg} / \mathrm{Kg}$, recuperado com o solvente isopropanol absoluto.

Alguns solventes orgânicos apresentam capacidade similar ao hexano na extração de óleos vegetais que o hexano, embora sejam menos tóxicos à saúde humana. Nesse sentido, a Food and Drug Administration (FDA) revisou em 2012 o Guia para Indústrias Q3C Impurezas: Solventes Residuais (FDA, 1997), documento resultante da Conferência Internacional em Harmonização (ICH) de Requerimentos Técnicos para registro de produtos farmacêuticos para uso humano. Tal guia recomenda quantidades consideradas seguras de solventes em produtos farmacêuticos e biológicos, destacando-se os solventes heptano e pentano como solventes menos tóxicos e com baixo risco à saúde humana (classe 3). Porém, segundo o documento, os solventes hexano e ciclohexano (classe 2) devem ser limitados em produtos farmacêuticos devido a sua inerente toxicidade apresentando nestes produtos concentrações limites máximas de $290 \mathrm{mg} / \mathrm{kg}$ e $3880 \mathrm{mg} / \mathrm{kg}$, respectivamente. Tal informação possibilita a investigação do efeito do uso de solventes classe 3 na extração 
de óleos vegetais apresentando menores riscos à saúde de manipuladores e consumidores.

Conkerton, Wan e Richard (1995) extraíram óleo de algodão em escala laboratorial utilizando os solventes heptano e hexano no Sistema HT6 Soxtec e, também, segundo o método Soxhlet de extração. Esses autores compararam os rendimentos de extração e a qualidade do óleo e farelo resultantes, sendo que a proporção solvente e farelo utilizada na extração foi de 10:1 (volume por massa). Os autores concluíram que heptano e hexano extraíram a mesma quantidade de óleo com quantidades similares de ácidos graxos livres e nenhuma alteração nas proteínas e perfil de aminoácidos. Entretanto, como reportado por Johnson e Lusas (1983) e confirmado neste trabalho, devido seu ponto de ebulição superior quando comparado ao hexano, o uso do heptano resulta no incremento de energia requerida para extrair óleo de algodão e maior gasto energético para dessolventização da miscela e farelos resultantes, o que deve ser mais bem avaliado a partir do estudo da viabilidade econômica do processo em plantas piloto, por exemplo.

Em uma iniciativa da Pfizer, uma das maiores Empresas Farmacêuticas do mundo, de incluir os princípios da química sustentável em seus medicamentos, procedimentos foram tomados para criar ferramentas que auxiliem a seleção de solventes e reagentes "verdes". Para tanto, Alfonsi et al. (2008) classificaram diversos solventes nos níveis preferíveis, aceitáveis e indesejáveis quanto à segurança de trabalho, uso operacional e considerações ambientais e reguladoras. Nesse contexto, etanol, isopropanol e água foram considerados preferíveis, os solventes ciclohexano e heptano foram considerados aceitáveis, enquanto que, devido a sua elevada inflamabilidade, pentano foi definido como indesejável.

No estudo comparativo entre o uso de solventes apolares na extração de óleo de algodão em sistema Soxtec, os seis solventes candidatos (hexano, heptano, isohexano, ciclopentano, ciclohexano e neohexano) extraíram teores de óleo de algodão maiores ou iguais a $90 \%$, sem alterações significativas na cor do óleo refinado e teor de ácidos graxos livres. Porém, o ciclohexano destacou-se devido sua maior capacidade de remoção de gossipol. Além disso, na etapa de dessolventização da miscela, a energia total requerida para recuperar um grama de isohexano de uma miscela, com 
concentração de $20 \%$, foi 2,2 \% menor que a mesma requerida pelo hexano. Devido a fatores tais como disponibilidade, custo e faixa preferível de temperatura operacional próxima ao hexano, heptano e isohexano apresentaram-se como os solventes mais apropriados para substituir o hexano (WAN et al., 1995a).

Após estudo em escala laboratorial, Wan et al. (1995b) reproduziram em planta piloto o experimento de extração e refino de óleo de algodão, a partir dos solventes hexano, heptano e isohexano, em extrator do tipo Expander® com capacidade de processamento de 300 toneladas de sementes de algodão por dia. Quanto ao tempo de residência no extrator, concentração da miscela e óleo residual, os dois solventes candidatos apresentaram eficiência de extração comparáveis ao hexano. O uso do heptano, devido a seu elevado ponto de ebulição, resultou no aumento da carga de energia necessária para dessolventização da miscela, reduzindo em 20 a $30 \%$ o rendimento diário de produção e, ainda, o óleo bruto obtido a partir deste solvente apresentou o menor teor de gossipol e maior conteúdo de fósforo. Já o uso do isohexano resultou em um rendimento de dessolventização de 10 a $20 \%$ maior do que o hexano, ou seja, devido seu baixo ponto de ebulição, menor energia foi requerida para sua remoção resultando, ainda, na redução em $40 \%$ no consumo de vapor da planta comparado a operação com hexano.

Ademais, o uso de misturas de solventes, dependo da proporção entre estes, pode promover um efeito sinérgico na extração de compostos de interesse, lipídeos e/ou compostos minoritários.

Hojilla-Evangelista e Johnson (2002) extraíram óleo de milho segundo o processo de extração sequencial a $56{ }^{\circ} \mathrm{C}$ utilizando os solventes etanol azeotrópico e a mistura etanol e hexano (70: 30, em massa) e avaliaram o impacto do uso de diferentes proporções entre solvente e flocos de milho $(1: 1 ; 1,5: 1 ; 2: 1$ e $3: 1$, em massa) na recuperação de óleo de milho. De modo geral, um maior conteúdo de óleo foi extraído utilizando etanol azeotrópico $(85 \pm 2 \%)$ e a mistura de solventes (93 $\pm 1 \%$ ), na proporção 3:1. Porém, em proporções solvente/soluto menores que 2:1, etanol azeotrópico apresentou extração de óleo significativamente menor que a mistura de solventes devido, principalmente, a sua maior polaridade. 
A extração de óleo de soja pelo método Sohxlet de extração utilizando solventes puros, misturas de solventes com água e misturas azeotrópicas de solventes polares e apolares resultou, após 2 horas de extração, para hexano e isopropanol rendimentos de 77 e $73 \%$, respectivamente. Para a mistura isopropanol e água (90:10, em volume) foi obtido rendimento de extração de $80 \%$ e para as misturas azeotrópicas, hexano e propanol (96:4, em volume), heptano e etanol (52:48, em volume) e hexano e isopropanol (78:22, em volume), foram obtidos valores de rendimento de 68,64 e $64 \%$, respectivamente (GANDHI et al., 2003).

A extração de óleo de microalga utilizando a mistura azeotrópica ciclohexano/ 1 butanol (90:10, em volume) através do método Soxhlet de extração apresentou rendimento de extração de óleo 34 \% superior ao valor obtido quando a extração foi realizada com solventes orgânicos puros (LONG; ABDELKADER, 2011).

Em relação a compostos minoritários, Treszczanowicz et al. (2001) realizaram estudos acerca da solubilidade do $\beta$-caroteno em diferentes solventes puros ou misturas de solventes. Foi possível observar um efeito sinérgico referente ao uso de misturas binárias de solventes, o que de fato permite inferir que a solubilidade do $\beta$ caroteno aumentou na maioria das misturas binárias de hidrocarboneto e acetona em relação a solubilidade nos solventes puros, conforme apresenta a Tabela 3.

Rahmalia, Fabre e Mouloungui (2015) utilizaram diferentes proporções de ciclohexano e acetona a fim de obter o maior rendimento de extração do carotenoide bixina presente no urucum, por meio da extração acelerada por solvente (ASE). Os autores concluíram que a extração utilizando a mistura ciclohexano:acetona (60:40\%), a $50{ }^{\circ} \mathrm{C}$, durante 5 minutos de aquecimento resultou no rendimento mais elevado de extração de bixina total (48 \%) em comparação com outras proporções entre os solventes utilizadas no estudo.

De maneira geral, pode-se inferir que os dados disponíveis na literatura acerca da obtenção do óleo rico em carotenoides presente no prensando de palma ainda são escassos, o que de fato evidencia a necessidade de um estudo apurado acerca da extração de óleo desse material oleaginoso. Desta forma, pode-se inferir que os solventes etanol, isopropanol, ciclohexano, heptano e suas misturas, apresentam 
grande potencial para extração de um óleo residual da fibra prensada de palma rico em carotenoides.

Tabela 3 Solubilidade de $\beta$-caroteno em diferentes solventes, a $20{ }^{\circ} \mathrm{C}$.

\begin{tabular}{cc}
\hline Solvente* $^{*}$ & Solubilidade $\mathbf{1 0}^{\mathbf{3}} \mathbf{( \mathbf { m o l } / \mathbf { l } )}$ \\
\hline 2-propanona & 0,222 \\
2-butanona & 1,02 \\
Ciclohexano & 2,65 \\
Hexano & 0,663 \\
Tolueno & 10,1 \\
Ciclohexano + 2-propanona & 4,26 \\
Hexano + 2-propanona & 1,34 \\
Ciclohexano + 2-butanona & 9,47 \\
Hexano + 2-butanona & 3,36
\end{tabular}

*Misturas binárias com fração molar de hidrocarboneto de aproximadamente 0,5.

Fonte: TRESZCZANOWICZ, T.; KASPRZYCKA-GUTTMAN, T.; TRESZCZANOWICZ, A.J. Solubility of $\beta$-Carotene in Binary Solvents Formed by Some Hydrocarbons with Cyclohexanone and 1-Octanol. Journal of Chemical \& Engineering Data, v. 46, n. 6, p. 1494-1496, 2001.

Com base nas considerações acima mencionadas, o presente estudo propõe a avaliação da viabilidade técnica do emprego de solventes ou misturas de solventes no processo de extração de óleo da fibra prensada de palma rico em carotenoides. Neste contexto, o item a seguir aborda aspectos relacionados aos parâmetros de solubilidade de Hansen, os quais podem apontar a existência ou não de sinergismo entre álcoois e hidrocarbonetos na extração de compostos de interesse.

2.4 Parâmetros de Solubilidade de Hansen

Os parâmetros de solubilidade foram primeiramente introduzidos por Hildebrand e Scott em 1950 (HILDEBRAND; SCOTT, 1950). A importância de se calcular os parâmetros de solubilidade do soluto e do solvente está relacionada a possibilidade de se poder estimar o grau de interação entre os componentes orientando a escolha de 
solventes que apresentem maior solubilidade do composto de interesse, sem a necessidade de realizar experimentos (DOMANSKA, 1990).

A Teoria de Scatchard-Hildebrand sugere que a solubilidade de um sólido é máxima no solvente no qual o parâmetro de solubilidade $\left(\delta_{2}\right)$ é o mesmo que o do soluto líquido $\left(\delta_{1}\right)$ e, neste caso, tanto o coeficiente de atividade do soluto $\left(\gamma_{1}\right)$, referente ao líquido subresfriado, quanto o coeficiente de atividade do solvente $\left(\gamma_{2}\right)$ são iguais à unidade (PRAUSNITZ et al., 1999). Dessa forma, os coeficientes de atividade para os componentes de uma mistura binária podem ser calculados segundo as Equações $1 \mathrm{e}$ 2:

$R T \ln \gamma_{1}=v_{1} \phi_{2}^{2}\left(\delta_{1}-\delta_{2}\right)^{2}$

$R T \ln \gamma 2=v_{2} \phi_{1}^{2}\left(\delta_{2}-\delta_{1}\right)^{2}$

Onde $\gamma$ refere-se ao coeficiente de atividade, $\boldsymbol{v}$ ao volume molar $\left(\mathrm{m}^{3} / \mathrm{mol}\right), \boldsymbol{\phi}$ à fração volumétrica e $\delta$ o parâmetro de solubilidade $\left(\mathrm{MPa}^{1 / 2}\right)$. Os componentes 1 e 2 referem-se ao soluto e solvente, respectivamente. A unidade do parâmetro de solubilidade no sistema internacional é $\mathrm{MPa}^{1 / 2}$.

Ainda, segundo a Teoria de Scatchard-Hildebrand, em uma mistura ternária o coeficiente de atividade do solvente misto pode ser calculado pela Equação 3 (DOMANSKA, 1990).

$R T \ln \gamma_{1}=v \phi_{2}^{2}\left(\delta_{1}-\delta\right)^{2}$

Onde:

$\delta=\frac{\left(\phi_{A} \delta_{A}\right)+\left(\phi_{B} \delta_{B}\right)}{\left(\phi_{A}+\phi_{B}\right)}$

$\phi_{2}=\frac{\left(x_{2} v_{2}\right)}{\left(x_{1} v_{1}+x_{2} v_{2}\right)}$ 
$\phi_{A}=\frac{\left(x_{A} v_{A}\right)}{\left(x_{B} v_{B}+x_{A} v_{A}\right)}$

$\phi_{B}=\frac{\left(x_{B} v_{B}\right)}{\left(x_{A} v_{A}+x_{B} v_{B}\right)}$

As equações 3 e 4 evidenciam que, se em uma determinada composição da mistura de solventes $A$ e $B$, a diferença entre os parâmetros de solubilidade da mistura de solventes $(\delta)$ e do soluto $(\delta 1)$ tender a zero, os valores dos coeficientes de atividade do soluto e do solvente serão iguais à unidade e, nesta situação, ocorrerá um máximo de solubilidade.

No entanto, uma vez que a Teoria de Hildebrand não considera, em nível atômico, as possíveis interações intermoleculares presentes na mistura, como interações não polares (D), interações dipolares moleculares $(P)$ e interações do tipo pontes de hidrogênio moleculares $(H)$, em meados de 1960 o pesquisador Charles Hansen percebeu que todas as ligações coesivas de um líquido são quebradas quando este evapora, portanto, estas ligações não polares devem ser contabilizadas no âmbito da energia da própria vaporização. Esta consideração resultou na divisão do parâmetro de solubilidade de Hildebrand, ou parâmetro total $\left(\delta_{T}\right)$, em três parâmetros, $\delta_{D}, \delta_{P}$ e $\delta_{H}$, os quais referem-se às interações não polares, dipolo moleculares e pontes de hidrogênio moleculares, respectivamente. As três interações intermoleculares presentes na mistura são denominadas parâmetros de solubilidade de Hansen ( $\mathrm{PSH}$ ( $\mathrm{MPa}^{1 / 2}$ ) (HANSEN, 2004). Desta forma, o parâmetro de Hildebrand pode ser obtido pela Equação 8.

$$
\delta_{T}^{2}=\delta_{D}^{2}+\delta_{P}^{2}+\delta_{H}^{2}
$$

Segundo Hansen (2004), o cálculo dos parâmetros para uma mistura de solventes é possível utilizando as frações volumétricas ou mássicas $\left(w_{i}\right)$ que foram 
adicionadas à mistura na análise dos respectivos parâmetros. Logo, os PSH para a mistura de solventes podem ser calculados segundo as Equações 9, 10 e 11.

$\delta_{D}^{\text {mistura }}=\sum_{i=1}^{i=n} \delta_{d i} w_{i}$

$\delta_{P}^{\text {mistura }}=\sum_{i=1}^{i=n} \delta_{p i} w_{i}$

$\delta_{H}^{\text {mistura }}=\sum_{i=1}^{i=n} \delta_{h i} w_{i}$

Ademais, estes três parâmetros de solubilidade de Hansen definem um espaço tridimensional, conhecido como o espaço de Hansen, ilustrado pela Figura 5, onde nele todos os solventes e solutos podem ser localizados.

Figura 5 Esfera de solubilidade de Hansen para cálculo da distância soluto-solvente $(\mathrm{Ra})$.

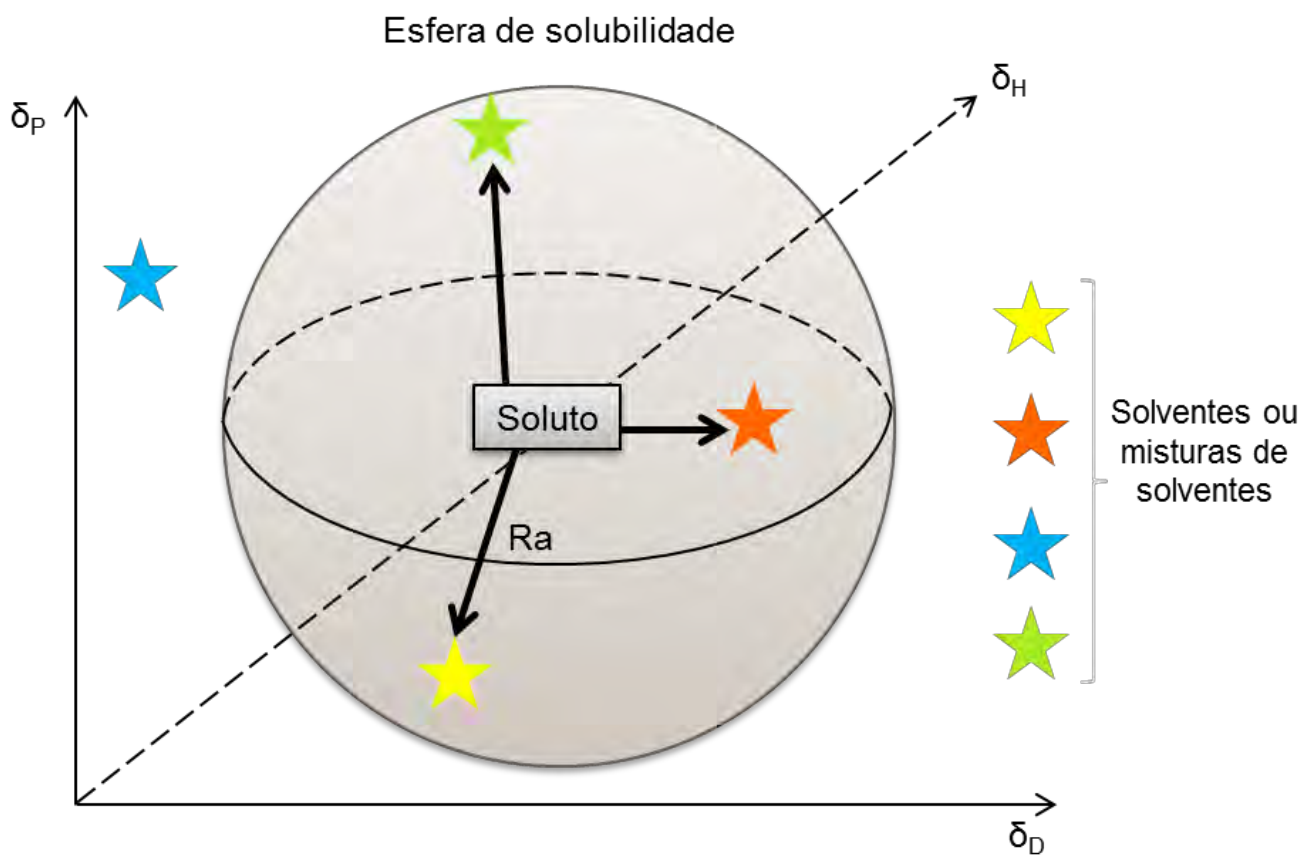

Fonte: Própria autoria. 
Enquanto um soluto pode ser visualizado como um ponto rodeado por sua esfera de solubilidade, todos os solventes e misturas de solventes localizados no interior deste volume são susceptíveis a solubilizar este soluto. Quanto mais próximos os parâmetros do soluto e solvente, ou mistura de solventes melhor será a solubilidade aproximandose, nestes casos, a distância soluto-solvente $(\mathrm{Ra})$ de zero. De fato, compostos com valores de PSH semelhantes ou próximos, apresentam uma elevada afinidade entre si.

A distância soluto-solvente, Ra, é definida de acordo com a Equação 12.

$R a^{2}=4\left(\delta_{D 1}-\delta_{D 2}\right)^{2}+\left(\delta_{P 1}-\delta_{P 2}\right)^{2}+\left(\delta_{H 1}-\delta_{H 2}\right)^{2}$

Com o intuito de predizer a solubilidade do minoritário de interesse em diferentes solventes, os parâmetros de Hansen de alguns solventes alcoólicos e hidrocarbonetos foram consultados no Handbook de Barton (1983). Os parâmetros de Hansen para diferentes solventes (BARTON, 1983) estão apresentados na Tabela 4.

Ozel e Gogus (2014) estimaram os parâmetros de Hansen para $\beta$-caroteno obtendo $17,4,0,8,1,7(\mathrm{MPa}) 1 / 2$ para $\delta \mathrm{D}, \delta \mathrm{P}$ e $\delta \mathrm{H}$, respectivamente, e parâmetro total (ठT) de 17,5 (MPa)1/2.

De maneira geral, os dados apresentados na Tabela 4 permitem inferir que os solventes da classe hidrocarboneto apresentam valores baixos ou nulos para os parâmetros $\delta \mathrm{P}$ e $\delta \mathrm{H}$ os quais foram próximos do valor obtido por Ozel e Gogus (2014) para $\beta$-caroteno, 0,8 e 1,7 (MPa)1/2, respectivamente, indicando preferência do soluto por estes solventes.

Tabela 4 Parâmetros de Hansen para diferentes solventes.

\begin{tabular}{ccccc}
\hline \multirow{2}{*}{ Solvente } & \multicolumn{5}{c}{$\boldsymbol{\delta}(\mathbf{M P a})^{1 / 2}$} \\
\cline { 2 - 5 } & $\boldsymbol{\delta}_{\mathbf{D}}$ & $\boldsymbol{\delta}_{\mathbf{P}}$ & $\boldsymbol{\delta}_{\mathbf{H}}$ & $\boldsymbol{\delta}_{\mathbf{T}}$ \\
\hline Etanol & 15,8 & 8,8 & 19,4 & 26,5 \\
Isopropanol & 15,8 & 6,1 & 16,4 & 23,5 \\
Hexano & 14,9 & 0 & 0 & 14,9 \\
Ciclohexano & 16,8 & 0 & 0,2 & 16,8 \\
Heptano & 15,3 & 0 & 0 & 15,3
\end{tabular}

Fonte: BARTON, A. F. M. Handbook of solubility parameters end other cohesion parameters. Boca Raton: CRC press, 1983. 
Ademais, Li et al. (2014) e Batista, Guirardello e Krähenbühl (2015) calcularam os parâmetros de Hansen para diferentes compostos presentes no óleo de canola, óleo de palma e óleo de coco, conforme pode ser observado na Tabela 5.

Tabela 5 Parâmetros de Hansen para compostos presentes no óleo de canola, para óleo de palma e óleo de coco.

\begin{tabular}{|c|c|c|c|c|}
\hline \multirow[b]{2}{*}{ Composto } & \multicolumn{4}{|c|}{$\delta(\mathrm{MPa})^{1 / 2}$} \\
\hline & $\delta_{D}$ & $\delta_{p}$ & $\delta_{H}$ & $\delta_{\mathrm{T}}$ \\
\hline Triacilglicerol $^{\mathrm{a}}$ & 15,8 & 4,7 & 2,2 & 17 \\
\hline Ácido Graxo Livre ${ }^{a}$ & $16,5 \pm 0,2$ & $3,1 \pm 0,3$ & $5,7 \pm 0,7$ & $17,7 \pm 0,4$ \\
\hline Tocoferol $^{\mathrm{a}}$ & 16,6 & 0,9 & 2,8 & 16,9 \\
\hline$\alpha-$ Tocotrienol $^{\mathrm{a}}$ & 17,5 & 0 & 3,5 & 17,8 \\
\hline Campesterol $^{\mathrm{a}}$ & 17,2 & 1,8 & 3,2 & 17,6 \\
\hline$\beta$-sitosterol ${ }^{\mathrm{a}}$ & 17,1 & 1,7 & 3 & 17,4 \\
\hline Óleo de palma ${ }^{b}$ & 17,54 & 3,34 & 4,08 & 18,31 \\
\hline Óleo de coco & 14,95 & 4,63 & 6,98 & 17,40 \\
\hline
\end{tabular}

Fonte: ${ }^{2} \mathrm{LI}, \mathrm{Y}$.; FINE, F.; FABIANO-TIXIER, A. S.; ABERT-VIAN, M.; CARRE, P.; PAGES, X.; CHEMAT, F. Evaluation of alternative solvents for improvement of oil extraction from rapeseeds. Comptes Rendus Chimie, v. 17, n. 3, p. 242-251, 2014.

${ }^{\mathrm{b}}$ BATISTA, M. M.; GUIRARDELLO, R.; KRÄHENBÜHL, M. A. Determination of Hansen Solubility Parameters of Vegetable Oils, Biodiesel, Diesel, and Biodiesel-Diesel Blends. Journal of American Oil Chemists' Society. 92 (2015), 95-109.

Ao se observar os dados apresentados na Tabela 5 nota-se uma certa similaridade entre os parâmetros de Hansen $\delta \mathrm{D}, \delta \mathrm{P}$ e $\delta \mathrm{H}$ apresentados para os componentes do óleo de canola, óleos de palma e de coco e os solventes da Tabela 4, tanto hidrocarbonetos como álcoois, o que permite inferir que a solubilidade de tais compostos pode ser modificada, maximizada por exemplo, se misturas entre os solventes forem utilizadas.

Dessa forma, este trabalho propõe o cálculo da distância soluto-solvente para $\beta$ caroteno e misturas de solventes (álcoois e hidrocarbonetos) em diferentes proporções. De fato, é desejável a obtenção de uma mistura de solventes com máxima afinidade pelo $\beta$-caroteno promovendo a obtenção de altos rendimentos de extração de óleo de palma rico em carotenoides. 


\section{OBJETIVOS}

O presente trabalho objetiva a valorização do subproduto da indústria do óleo de palma através do estudo da viabilidade técnica do emprego de potenciais solventes e misturas de solventes no processo de extração do óleo da fibra prensada de palma a fim de se obter um produto rico em carotenoides. Para a mistura de solventes, a escolha da proporção entre solventes polares (álcoois de cadeia curta) e apolares (hidrocarbonetos) a ser empregada foi realizada por meio do cálculo da distância solutosolvente (Ra). Para se atingir o objetivo proposto, as atividades realizadas se concentraram em:

\section{i. Caracterização físico-química da fibra prensada de palma;}

ii. Cálculo da distância soluto-solvente $(\mathrm{Ra})$ para as misturas entre solventes alcoólicos e hidrocarbonetos propostos, a fim de obter os valores das frações mássicas das misturas compreendidas por hexano e etanol; hexano e isopropanol; ciclohexano e etanol; ciclohexano e isopropanol; heptano e etanol; heptano e isopropanol;

iii. Determinação experimental de dados de extração de óleo de fibra prensada de palma utilizando-se como solventes etanol, isopropanol, hexano, ciclohexano e heptano e as misturas entre estes solventes alcoólicos e hidrocarbonetos, em extrator em batelada, a $60^{\circ} \mathrm{C}$;

iv. Determinação experimental de dados de extração de óleo de fibra prensada de palma utilizando-se como solventes etanol, isopropanol e hexano e as misturas entre estes solventes alcoólicos e hexano, em coluna empacotada de leito fixo, a $55^{\circ} \mathrm{C}$;

v. Avaliação do impacto dos tipos de solventes e misturas de solventes empregados nos experimentos de extração sólido-líquido, a partir da caracterização do óleo de fibra prensada de palma em termos de conteúdo total de carotenoides, composição de 
carotenoides em termos de $\alpha$ - e $\beta$ - carotenos e licopeno, perfil de ácidos graxos, além do cálculo do rendimento do processo de extração de óleo. 
4 MATERIAL E MÉTODOS

\subsection{Material}

\subsubsection{Reagentes}

- Fibra prensada de palma (Agropalma);

- $\quad \beta$-caroteno (Sigma-Aldrich, 7235-40-7);

- $\quad$-caroteno (Sigma-Aldrich, 488-99-5);

- Licopeno (Sigma-Aldrich, 502-65-8);

- Etanol (Synth, 502-65-8);

- Isopropanol (Synth, 67-63-0);

- Hexano (Synth, 110-54-3);

- Hexano grau HPLC (Merck, 110-54-3);

- Isopropanol grau HPLC (Merck, 67-63-0);

- Ciclohexano (Synth, 110-82-7);

- Heptano (Synth, 142-82-5);

- Hidróxido de Sódio (Merck, 1310-73-2);

- Solução Karl Fischer isenta de piridina (Sigma-Aldrich);

- Óleo de calibração para viscosímetro Stabinger APS3 (Reino Unido);

- Clorofórmio (Synth, 67-66-3);

- Metanol absoluto (Merck, 67-56-1);

- Diclorometano grau HPLC (Merck, 75-09-2);

- Acetonitrila grau HPLC (Merck, 75-05-8);

- Éter etílico (Synth, 60-29-7);

- Mistura de padrões de ésteres metílicos de ácidos graxos (Sigma-Aldrich);

- Padrão interno metiltridecanoato (Sigma-Aldrich, 1731-88-0);

- $\operatorname{edTA}($ Leco). 


\subsubsection{Equipamentos}

- Extrator em batelada em aço inoxidável (Marconi, modelo MA483/EC2, Brasil);

- Coluna de vidro encamisada (FGG, Brasil);

- UPLC/MS (Waters, ACQUITY UPLCH-Class Xevo® TQ-S, EUA);

- Estufa de convecção forçada (Nova Orgânica, modelo N035/3, Brasil);

- Bomba de vácuo (Tecnal, modelo TE058, Brasil);

Bomba peristáltica (Cole Parmer Masterflex, modelo 77200-60, EUA);

- Balança analítica eletrônica (0,0001 g) (Adam, modelo PW254, Reino Unido);

- Balança analítica eletrônica de precisão $(0,00001 \mathrm{~g})$ (Sartorius, modelo CPA 225D, Alemanha);

- Balança semi-analítica (Adam, modelo PGW1502i, Reino Unido);

- Banho termo estático digital (Marconi, modelo MA184, Brasil);

- Espectrofotômetro UV-Visível (Shimadzu, modelo UV 1650PC, Japão);

- Cromatógrafo gasoso com injetor automático (Shimadzu, modelo GC2010, Japão);

- Rotaevaporador (Heidolph, modelo Hei-VAP Silver, Alemanha);

- Titulador Karl Fischer Coulométrico (Metrohm, modelo 756 Coulometer 899, Suíça);

- Deionizador de água (Millipore, modelo Direct-Q 3, EUA);

- Titulador potenciométrico automático (Methohm, modelo 848 Titrino Plus, Suíça);

- Viscosímetro Stabinger (Anton Paar, modelo SVM 3000, Áustria);

- Sistema de extração de gordura a alta temperatura (Ankom, modelo XT10, EUA);

- Sistema completo para determinação de nitrogênio/proteína por combustão (Leco, modelo FP-528, EUA);

- Moinho de facas (Marconi, modelo MA340, Brasil);

- Analisador de tamanho de partículas por difração à laser (Shimadzu, modelo SALD-201V, Japão);

- Peneiras Tyler (Bertel, maq 16919, série 0401, Brasil). 


\subsubsection{Diversos}

- Gases especiais para cromatografia gasosa (ar sintético, hélio, hidrogênio) e para determinação de nitrogênio pelo método de combustão (ar comprimido, hélio, oxigênio) (Linde);

- Solventes de alto grau de pureza para espectrofotometria e cromatografia;

- Vials para cromatografia gasosa;

- Cubetas para espectrofotometria UV/visível;

- Vidrarias em geral (béqueres, erlenmeyers, placas de Petri, balões volumétricos calibrados, etc);

- Termômetros calibrados;

- Seringas com agulhas para amostragem;

- Papel filtro XT4 (Ankom);

- Filtro de papel (Brigitta, $\left.n^{\circ} 102\right)$

- Folhas de estanho (Leco);

- Frascos de penicilina, tampas de borracha e lacres de alumínio;

- Filtros de seringa 0,45 $\mu \mathrm{m}$ (Allcrom);

- Mangueiras para conexão em coluna de extração (Masterflex, Cole-Parmer,1800-627-8373);

- Manta de temperatura em formato cilíndrico. 


\subsection{Metodologia}

\subsubsection{Caracterização da fibra prensada de palma}

\subsubsection{Umidade inicial, secagem e homogeneização da fibra prensada de palma}

A FPP (Agropalma) foi submetida à análise de umidade em estufa convectiva a $130 \stackrel{\circ}{\circ}$ por 3 horas (Ac 2-41, AOCS, 2009). Para o adequado armazenamento da matéria-prima devido ao alto teor de umidade, esta foi submetida à secagem por 24 horas em estufa convectiva a $40 \stackrel{\circ}{ } \mathrm{C}$, segundo metodologia sugerida por Cardenas-Toro et al. (2014). Com o intuito de homogeneizar a amostra, a fibra prensada de palma seca foi triturada utilizando um moinho de facas (Marconi, modelo MA340) e, após este procedimento, foi acondicionada em sacos plásticos e armazenada em freezer.

\subsubsection{Composição centesimal}

A FPP foi caracterizada em termos de umidade (Ac 2-41, AOCS, 2009), teor de lipídeos (Am 5-04, AOCS, 2009), proteína bruta (Ba 4f-00, 2009) e cinzas (AOAC, 2007). A análise de fibras foi realizada no Laboratório de Frutas e Hortaliças da Escola Superior de Agricultura "Luiz de Queiroz" (ESALQ-USP) segundo metodologia de Asp et al. (1983). O teor de carboidratos não fibrosos (CNF \%) foi obtido por diferença, considerando os teores dos diferentes componentes (cinzas (\%), lipídeos (\%), proteínas $(\%)$, fibras (\%)) em base seca. 


\subsubsection{Determinação do tamanho médio de partículas}

A determinação da distribuição granulométrica e do tamanho médio das partículas da FPP foi realizada utilizando peneiras Tyler, com meshs 10, 14, 20, 28, 35 e 48, e o equipamento de difração a laser, respectivamente.

Para a primeira análise pesaram-se cerca de $150 \mathrm{~g}$ de FPP triturada. Essa massa foi mantida sob agitação por 10 minutos e, na sequência, verificou-se a massa de amostra retida em cada peneira e no fundo, sendo que o material retido no fundo foi recolhido. Após, o diâmetro médio das partículas retidas nas peneiras Tyler $\left(\mathrm{dm}_{\mathrm{ty}}\right)$ foi determinado de acordo com a metodologia descrita por ASAE (1995) utilizando a Equação 13:

$$
d m_{t y}=\log ^{-1}\left\{\frac{\sum_{i=1}^{n} w_{i} \log \left(d_{i} \times d_{i+1}\right)^{0,5}}{\sum_{i=1}^{n} w_{i}}\right\}
$$

Onde wi é a massa retida na i-ésima peneira $(\mathrm{g})$, $d_{i}$ é a abertura da i-ésima peneira $(\mathrm{mm})$ e $\mathrm{d}_{\mathrm{i}}+1$ é a abertura da peneira $\mathrm{i}+1(\mathrm{~mm})$.

Uma pequena fração do material retido no fundo foi suspensa em vaselina líquida para realização da análise por difração a laser $\left(\mathrm{dm}_{\mathrm{dl}}\right)$ para verificação da distribuição granulométrica deste material. O diâmetro médio das partículas de fundo analisadas por difração a laser é fornecido pelo próprio equipamento o qual utiliza as equações 14 e 15 para o cálculo:

$$
\begin{aligned}
& d m_{d l}=10^{\mu} \\
& \mu=\frac{1}{100} \sum_{j=1}^{n} q_{j} \frac{\log _{10} x_{j}+\log _{10} x_{j+1}}{2}
\end{aligned}
$$

Onde $x_{j}$ é o diâmetro da partícula $(\mu \mathrm{m})$ e qj é a distribuição diferencial (\%). 
Após a obtenção dos diâmetros médios das partículas, calculados a partir das equações descritas acima, fez-se a média ponderada dos valores obtidos para determinação do diâmetro médio global das partículas da FPP $\left(\mathrm{dm}_{\mathrm{p}}\right)$.

\subsubsection{Caracterização do óleo de fibra prensada de palma extraído a frio}

A extração a frio do óleo de fibra prensada de palma foi realizado segundo método sugerido por Neoh et al. (2011), com a matéria-prima colocada em contato com hexano à temperatura ambiente, por 8 horas, na proporção mássica de 1:5 sólido:solvente. O extrato, contendo óleo residual extraído e solvente foi submetido à rotaevaporação a $40{ }^{\circ} \mathrm{C}$, iniciando-se o vácuo a $20 \mathrm{KPa}$ e diminuindo-se até $13 \mathrm{KPa}$ para garantir a total separação do óleo, o qual foi submetido a análises subsequentes.

\subsubsection{Determinação da composição em ácidos graxos e índice de iodo via cromatografia gasosa}

Primeiramente o óleo de FPP foi submetido à hidrólise e esterificação e em seguida, a análise do perfil de ácidos graxos foi realizada por cromatografia gasosa dos ésteres metílicos de ácidos graxos, de acordo com o método oficial 1-62 da AOCS (2009), utilizando como padrão interno metiltridecanoato (ZENEBON et al., 2008).

Utilizou-se um cromatógrafo gasoso Shimadzu 2010 AF (Japão), com injetor automático (Shimadzu, modelo AOC 20i, Japão) e detector de ionização em chama nas seguintes condições experimentais: coluna capilar altamente polar de biscianopropil polisiloxano 0,20 $\mu \mathrm{m}, 100 \mathrm{~m} \times 0,25 \mathrm{~mm}$ i.d. ( SP -2560 , Supelco, Bellefonte, PA, USA), hélio como gás de arraste (velocidade linear de $19,5 \mathrm{~cm} / \mathrm{seg}$ ); temperatura do injetor de $250{ }^{\circ} \mathrm{C}$, temperatura da coluna de $140^{\circ} \mathrm{C}$ (5 minutos), $140 / 240{ }^{\circ} \mathrm{C}$ (taxa de $4^{\circ} \mathrm{C} / \mathrm{min}$ ), $240^{\circ} \mathrm{C}$ (15 minutos); temperatura do detector de $260^{\circ} \mathrm{C}$ e volume de injeção de $1,0 \mu \mathrm{m}$; Split 100:1.

Os ácidos graxos foram identificados por comparação com padrões externos adquiridos da Supelco (Bellefonte, PA, USA). A quantificação foi realizada com base 
nas relações de área de cada ácido graxo com a área do padrão interno, utilizando os fatores de correção de resposta do detector de ionização em chama e de conversão de ésteres metílicos de ácidos graxos para ácido graxo.

O cálculo do índice de iodo foi realizado conforme descrito no método oficial $\mathrm{Cd}$ 1c-85(97) da AOCS (1998).

\subsubsection{Determinação do teor de ácidos graxos livres (AGL) do óleo de FPP}

A acidez livre do óleo de FPP foi determinada utilizando-se a massa molar média dos ácidos graxos livres, calculada com base na análise cromatográfica (item 4.2.2.1). A titulação foi realizada com hidróxido de sódio $(\mathrm{NaOH})$ pelo método a frio 2201 da IUPAC (1979), modificado por conta da utilização de um titulador potenciométrico automático.

A acidez livre (\%, em massa) das amostras foi calculada conforme a Equação (16).

$$
A G L \%=\left(\frac{M M \times N N a O H \times V o l}{M \times 10}\right)
$$

Onde: $\mathrm{MM}$ = massa molar média dos ácidos graxos livres $(\mathrm{g} / \mathrm{mol})$;

$\mathrm{N}_{\mathrm{NaOH}}=$ normalidade da solução de $\mathrm{NaOH}$;

$\mathrm{Vol}=$ volume de $\mathrm{NaOH}$ gasto na titulação $(\mathrm{mL})$;

$\mathrm{M}=$ massa de amostra $(\mathrm{g})$.

\subsubsection{Determinação do teor de carotenoides no óleo de FPP}

O óleo de FPP foi submetido à análise de teor de carotenoides totais expresso como $\beta$-caroteno por espectrofotometria segundo metodologia do Palm Oil Research Institute of Malaysia (PORIM, 1990).

Primeiramente foi construída a curva de calibração (do tipo $Y=A^{*} X$, em que $Y$ é a absorbância, $X$ é o teor de $\beta$-caroteno em $g$ caroteno/g solução e A é o coeficiente 
angular da reta) utilizando-se soluções com composições conhecidas de $\beta$-caroteno (Sigma-Aldrich) em hexano para cromatografia líquida (Merck). Determinou-se a absorbância em espectrofotômetro na região do visível no comprimento de onda de 450 nm, comprimento onde ocorre a máxima absorção, segundo Porim (1990). Logo, obteve-se experimentalmente uma curva de calibração, conforme mostrado na Figura 6.

Os pontos experimentais mostrados na Figura 6 foram submetidos a regressão linear sendo obtido um coeficiente de determinação $\left(R^{2}\right)$ igual a 0,9982 . A relação linear obtida para a absorbância em função da composição está representada pela Equação 17.

$$
\text { Absorbância }(n m)=166251 \times \text { Composição }\left(\frac{\text { g betacaroteno }}{g \text { solução }}\right)
$$

Figura 6 Curva de calibração para $\beta$-caroteno em hexano no comprimento de onda de $450 \mathrm{~nm}$.

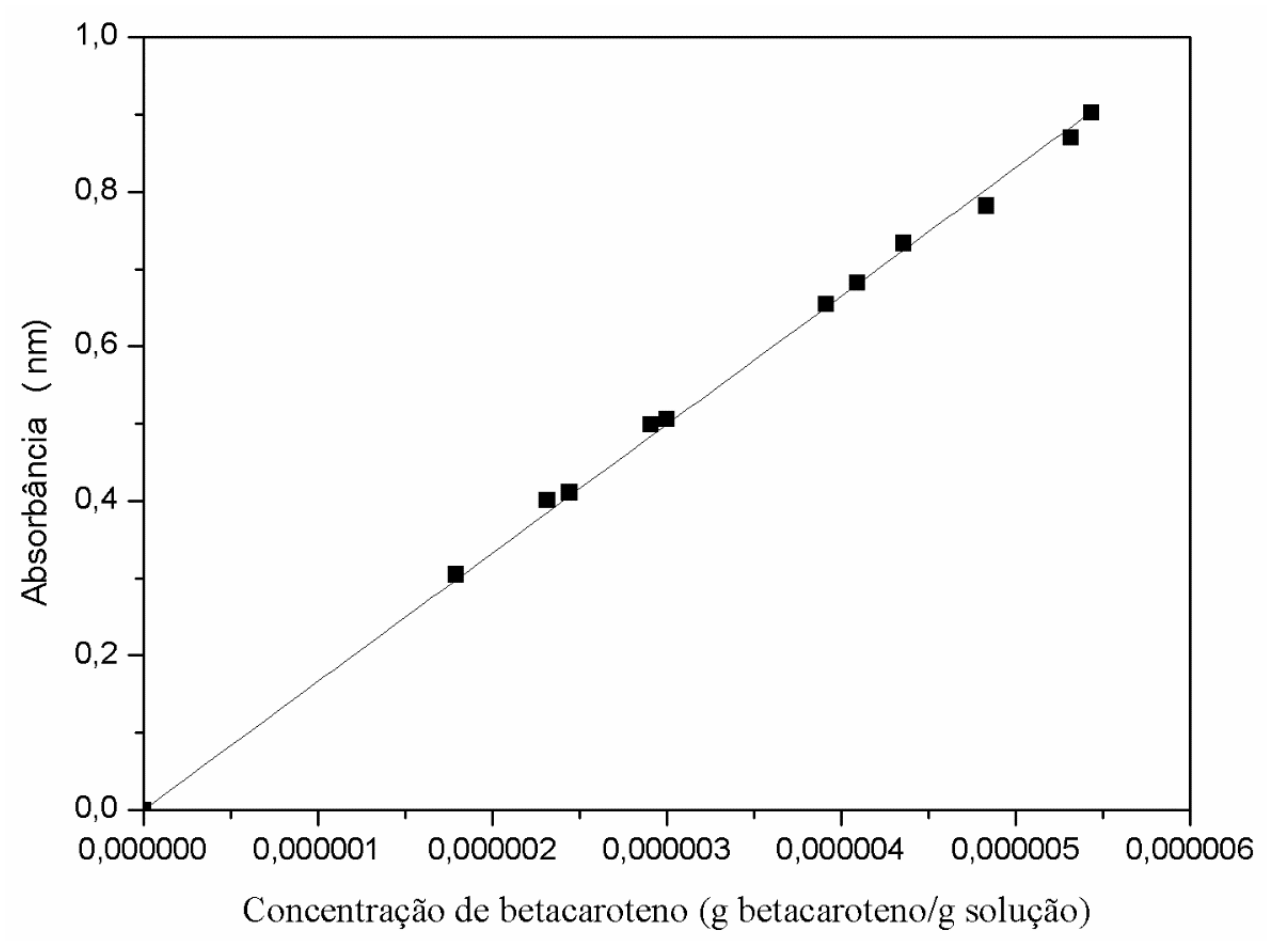

Fonte: Própria autoria. 


\subsubsection{Determinação experimental de dados de massa específica e viscosidade dos solventes puros e misturas de solventes utilizados nos experimentos de extração de óleo}

Os valores de massa específica e viscosidade dinâmica foram determinados no equipamento Stabinger Viscosimeter (Anton Paar, modelo SVM 3000). Inicialmente, o equipamento foi programado para determinação de massa específica e viscosidade nas temperaturas de 25 a, no máximo, $70^{\circ} \mathrm{C}$, em intervalos de $5^{\circ} \mathrm{C}$. Nesta dissertação, os valores de massa específica e viscosidade de solventes puros e misturas de solventes não puderam ser determinados de forma padronizada quanto a faixa de temperatura adotada devido a diferença de volatilidade dos solventes. Todas as medidas foram realizadas pelo menos em triplicata.

As amostras (aproximadamente $2,5 \mathrm{~mL}$ ) foram injetadas diretamente no equipamento previamente calibrado com óleo APS3 (Reino Unido), que após estabilização na temperatura desejada $\left( \pm 0,005{ }^{\circ} \mathrm{C}\right)$ forneceu o resultado direto da massa específica, em g/cm³ $( \pm 0,0002)$ e da viscosidade dinâmica, em mPa.s $( \pm 0,001)$. O equipamento possui faixas de medição de densidade entre 0,65 a $3,0 \mathrm{~g} / \mathrm{cm}^{3}$, e de análise de viscosidade dinâmica, entre 0,2 a $20.000 \mathrm{mPa}$.s.

Os dados de massa específica e viscosidade dinâmica foram submetidos a regressão linear utilizando o programa Origin $®$ Pro (versão 8.0).

\subsubsection{Cálculo das constantes dielétricas dos solventes utilizados experimentos de extração de óleo}

nos

As constantes dielétricas dos solventes utilizados na etapa de extração sólidolíquido foram calculadas para avaliar o efeito desta propriedade nos resultados de rendimento de extração obtidos.

A determinação dos valores de constante dielétrica ( $\mathrm{Di}$, adimensional) para os solventes puros e para as misturas de solventes foi realizada segundo Equação 18 proposta por Wohlfarth (2015). 


$$
D i=A+B T+C T^{2}+D T^{3}
$$

Onde T é a temperatura absoluta em Kelvin (K) e A, B, C e D são constantes da equação para cada composto (seus valores podem ser visualizados no Anexo $A$ ).

No caso das misturas de solventes hidrocarbonetos e álcoois foi utilizada a Equação 19, proposta por Tir et al. (2012).

$$
D i=D i_{a} \times w a+D i_{b} \times w b
$$

Onde, wa e wb são as frações mássicas dos solventes hidrocarbonetos (a) e álcoois (b), e $D_{a}$ e $D_{b}$ são as constantes dielétricas para os componentes solventes hidrocarbonetos (a) e álcoois (b) em função da temperatura.

\subsubsection{Cálculo da distância soluto-solvente (Ra) para escolha das melhores misturas de solventes}

Segundo Hansen (2004), o cálculo dos PSH para uma mistura de solventes é possível utilizando frações volumétricas ou mássicas $\left(w_{i}\right)$ que foram adicionadas à mistura na análise dos respectivos parâmetros (vide equações 9 a 11). Uma vez obtidos os valores dos PSH para os solventes propostos neste trabalho, conforme apresentado na Tabela 4 (BARTON,1983), para o $\beta$-caroteno (OZEL; GOGUS, 2014) e para o óleo de palma (BATISTA, 2015) pôde-se calcular então a distância soluto-solvente, $R a$, $(\mathrm{MPa})^{1 / 2}$, segundo a Equação 12 onde os subíndices 1 e 2 referem-se ao soluto e solvente, respectivamente.

A escolha das composições das misturas entre os solventes hidrocarbonetos (hexano, heptano e ciclohexano) e álcoois de cadeia curta (etanol e isopropanol) foi realizada mediante a obtenção de valores de Ra iguais a Ra calculada entre o soluto $\beta$ caroteno e os solventes hidrocarbonetos puros, pois estes possuem capacidade superior em solubilizar os carotenoides por apresentarem valores de parâmetros de solubilidade de Hansen (PSH) próximos, como foi descrito anteriormente no item 2.4. A 
rotina de cálculos para melhor ilustrar como foram decididas as composições da mistura está apresentada no Apêndice A.

Dessa forma, segundo a Equação 12, foram calculadas as Ra das misturas de solventes adicionando frações mássicas crescentes de solvente alcoólico ao solvente hidrocarboneto, até obter $\mathrm{Ra}$ igual ao valor referente a $\mathrm{Ra}$ para o solvente hidrocarboneto puro.

\subsubsection{Extração sólido-liquido de óleo de FPP em um estágio em extrator em batelada}

Para a obtenção dos dados de extração sólido-líquido de óleo de FPP com diferentes solventes foi utilizado um extrator, Figura 7 , construído em aço inoxidável. 0 tampo do equipamento é dotado de manômetro, válvula de escape (sistema de segurança) e rotor. $O$ extrator é vedado hermeticamente, evitando perdas de massa por evaporação. Os controles da temperatura e da velocidade de agitação são realizados por controladores próprios do equipamento.

Os sistemas sólido-líquido foram obtidos adicionando-se massas conhecidas de FPP (acondicionada em papel filtro, resistente ao ataque pelo solvente e permeável ao solvente e ao extrato), contactando-a com massa conhecida de solvente. O extrator foi submetido a agitação de $300 \mathrm{rpm}$ até a temperatura atingir o valor desejado e mantido sob agitação constante por cinco horas, para garantir a condição de equilíbrio. Este tempo de contato foi estabelecido com base em experimentos preliminares de cinética de extração os quais não foram mostrados nesta dissertação.

$\mathrm{O}$ valor de temperatura de extração, de $60^{\circ} \mathrm{C}$ foi definido com base no valor da temperatura de ebulição do solvente com a maior pressão de vapor, respeitando uma margem de segurança de aproximadamente $10{ }^{\circ} \mathrm{C}$. Mediante estudos preliminares, a maior razão mássica sólido:solvente que possibilitou $\mathrm{o}$ uso deste equipamento garantindo a total imersão da FPP nos solventes propostos foi de 1:7.

Após este tratamento, amostras da fase extrato foram retiradas pela válvula localizada na parte inferior do vaso e submetidas às análises de composição e a fase 
rafinado foi submetida à pesagem, em balança semi-analítica, para posterior cálculo do índice de retenção de solução aderida às fibras.

Figura 7 (a) Extrator utilizado para obtenção de dados de extração sólido-líquido em um estágio. (b) Detalhe interno no extrator.

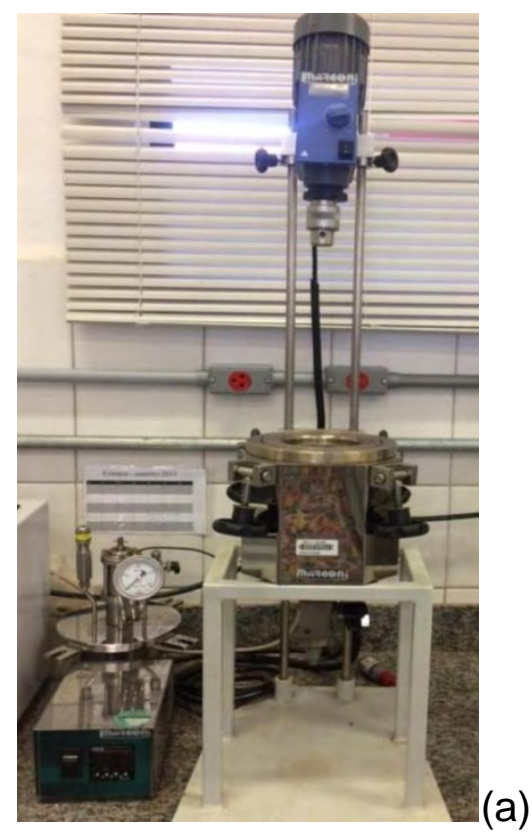

Fonte: Própria autoria.

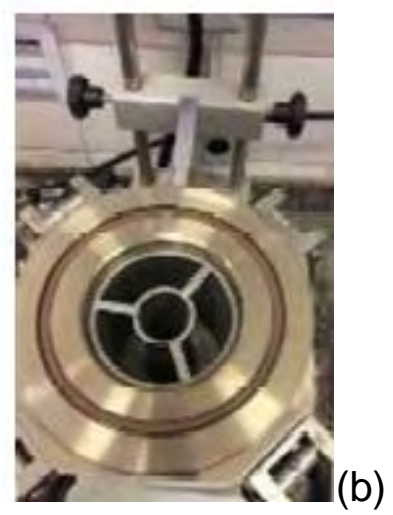

(b)

\subsubsection{Extração sólido-líquido de óleo de FPP em coluna empacotada de leito fixo}

\subsubsection{Ensaios de cinética de extração de óleo de FPP utilizando-se etanol}

Os ensaios de cinética de extração de óleo de FPP em coluna, utilizando etanol, foram realizados nos tempos de $15,30,60$ e 90 minutos, a $55 \pm 3^{\circ} \mathrm{C}$.

A coluna de vidro encamisada possui $2,6 \mathrm{~cm}$ de diâmetro interno, $5,4 \mathrm{~cm}$ de diâmetro externo e $63 \mathrm{~cm}$ de comprimento, porém foi adicionado um aparato metálico permitindo a utilização de apenas $15 \mathrm{~cm}$ do comprimento da mesma, objetivando a minimização da utilização de matéria-prima. O bombeamento dos solventes utilizados foi realizado por bombas peristálticas, o sistema foi aquecido segundo o auxílio de um banho termostático e todas as mangueiras conectadas foram vedadas hermeticamente 
com o auxílio de uma manta de temperatura, conforme esquema representado pela Figura 8.

Figura 8 Esquema de coluna de vidro encamisada acoplada a um banho termoestático e a duas bombas peristálticas.

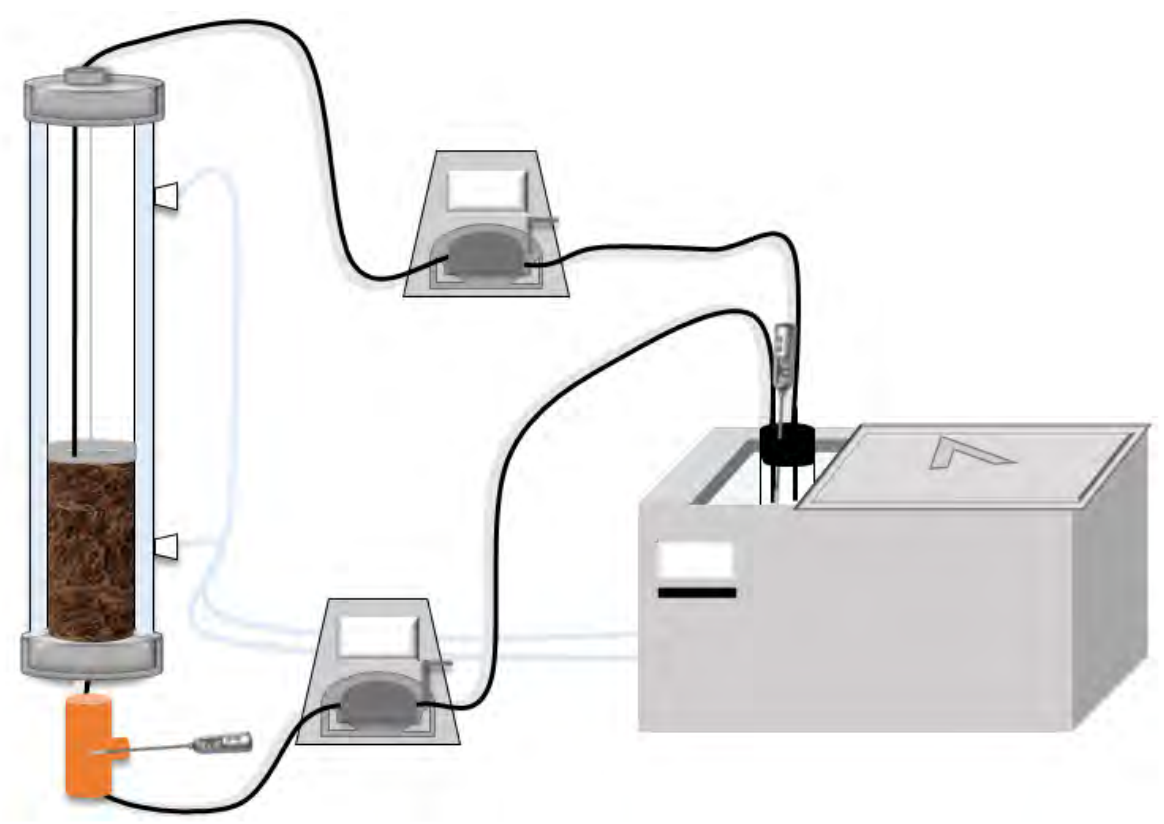

Fonte: Própria autoria.

Massa conhecida de FPP foi introduzida na coluna pelo topo, acoplado o aparato metálico, a fim de manter o material sólido fixo e, em seguida, a coluna foi fechada. $\mathrm{O}$ conteúdo de solvente necessário para garantir a razão mássica 1: 4 foi devidamente pesado em balança semi-analítica, e adicionado a um frasco de vidro resistente à alta temperatura e com tampo de plástico (Schott), o qual permaneceu no banho termo estático até atingir a temperatura de $60{ }^{\circ} \mathrm{C}$. Posteriormente, procedeu-se com $\mathrm{o}$ acionamento das bombas e enchimento da coluna pela parte inferior do equipamento na vazão de $20 \mathrm{~mL} / \mathrm{s}$. A temperatura de entrada do solvente na coluna foi monitorada ao longo de todo o experimento, permanecendo em torno de $55 \pm 3^{\circ} \mathrm{C}$. A contagem do tempo inicial de extração deu-se com a observação do retorno da fase líquida ao frasco Schott, o qual permaneceu no banho termoestático. 


\subsubsection{Extração sólido-liquido em coluna empacotada de leito fixo}

Foram realizados experimentos de extração sólido-líquido de óleo de FPP utilizando-se os solventes etanol, isopropanol, hexano e as misturas de hexano e etanol e hexano e isopropanol, em coluna empacotada de leito, a qual permitiu a utilização de uma razão sólido:solvente de 1:4, em massa, sendo, portanto, possível a utilização de menor quantidade de solvente se comparado aos experimentos em batelada (item 4.2.6).

A determinação do tempo de extração sólido-líquido, de 1 hora e 30 minutos, foi realizada segundo ensaios de cinética de extração de óleo de FPP utilizando-se etanol, descritos no item 4.2.7.1.

\subsubsection{Análises de caracterização das fases extrato e rafinado}

As análises de caracterização das fases extrato e rafinado, independentemente do tipo de configuração do equipamento de extração utilizado serão descritas nos itens a seguir.

\subsubsection{Determinação do conteúdo de água nos solventes e fase extrato e cálculo da transferência de água (\%) para a fase extrato}

O teor de água nos solventes e nos extratos provenientes dos experimentos de extração foi determinado pelo método oficial de titulação Karl Fischer Ca 2e-84 (AOCS, 2009). O cálculo da transferência de água para a fase extrato foi realizado segundo Equação 20, conforme sugerido por Rodrigues, Aracava e Abreu (2010).

Tágua $(\%)=100 \frac{m^{F E} w_{\text {àgua }}^{F E}}{m^{F P P} w_{\text {àgua }}^{F P P}}$ 
Onde: $m^{F E}=$ massa da fase extrato $(\mathrm{g})$, em base úmida; $w_{\text {água }}^{F E}$ fração mássica de água na fase extrato; $m^{F P P}=$ massa de $\operatorname{FPP}(\mathrm{g})$, em base úmida e $w_{\text {água }}^{F P P}=$ fração mássica de água na FPP. Neste caso, a massa da fase do extrato foi determinada pelo balanço de massa usando a metodologia sugerida por Marcilla et al. (1995) e adaptado para sistemas de extração sólido-líquido por Rodrigues e Oliveira (2010).

\subsubsection{Determinação do conteúdo de solvente}

O teor de solvente nas fases extrato e rafinado provenientes dos experimentos de extração foi determinado, em quintuplicata, por evaporação em estufa de convecção forçada, a $100^{\circ} \mathrm{C}$, até peso constante.

\subsubsection{Análises no óleo rotaevaporado}

As operações envolvidas na recuperação do óleo de FPP estão descritas no item 4.2.2, bem como sua caracterização quanto ao conteúdo de ácidos graxos livres (AGL), composição em ácidos graxos via cromatografia gasosa e teor de $\beta$-caroteno, segundo os procedimentos descritos nos itens 4.2.2.1, 4.2.2.2 e 4.2.2.3, respectivamente. Em adição, o óleo de FPP foi caracterizado em termos de sua composição em carotenoides, como exposto a seguir.

\subsection{Determinação do conteúdo de carotenoides em UPLC/MS}

\subsection{Preparo das amostras}

Foram construídas curvas de calibração com os padrões $\beta$-caroteno, $\alpha$-caroteno e licopeno (Apêndice $B$ ) sendo estas diluídas, primeiramente, em diclorometano e, em seguida, foram feitas diluições consecutivas com acetonitrila até a obtenção de concentração de $1000 \mathrm{ng} / \mathrm{mL}$ para cada um. Após, foi elaborado um mix dos três padrões diluindo-o com acetonitrila nas concentrações de 5, 10, 25, 30, 50 e $100 \mathrm{ng} / \mathrm{mL}$. 
Os dados obtidos foram ajustados por regressão linear e as correspondentes equações foram geradas para a quantificação de cada componente. Para análise do conteúdo dos carotenoides presentes nos óleos de FPP, aproximadamente $0,0010 \mathrm{~g}$ de óleo de FPP foram adicionados a $1000 \mu \mathrm{L}$ de diclorometano, sendo a solução diluída com acetonitrila a $100 \mathrm{ng} / \mathrm{mL}$. Cerca de $2 \mathrm{~mL}$ desta solução, coletada com o auxílio de uma pipeta, foi adicionada a um vial, o qual foi acondicionado no UPLC/MS para análise.

\subsection{Metodologia}

As análises em UPLC/MS foram realizadas considerando a ionização por electrospray (ESI) no modo positivo (ESI+), utilizando metodologia adaptada de Ansolin (2017). O volume de injeção foi de $10 \mathrm{~mL}$ e a separação cromatográfica foi obtida com uma pré-coluna e coluna ambas da marca Waters BEH C18 $(2,1 \mathrm{~mm} \times 50 \mathrm{~mm}, 1,7 \mu \mathrm{m}$ de tamanho de partícula). A temperatura do forno da coluna foi mantida a $35 \stackrel{\circ}{\circ}$ e utilizou-se um gradiente de fase móvel consistindo de água com $0,1 \%$ de ácido fórmico como fase A e acetonitrila + isopropanol (80:20, em volume) com 0,1\% de ácido fórmico como fase $B$ nas seguintes condições: $100 \%$ de fase $A$ em $0,0 \mathrm{~min} ; 100-10 \%$ de fase $A$ de 0,4 a 1,0 min, $10-0 \%$ de fase $A$ de 1,0 a 5,0 min, $0 \%$ de fase $A$ de 5,0 a $10 \mathrm{~min}$ e $0-100 \%$ de fase $A$ de 10,0 a $10,1 \mathrm{~min}$ a um fluxo de $0,5 \mathrm{~mL} / \mathrm{min}$.

$A$ análise de massas foi realizada em um detector Waters triplo quadrupolo (triple quadrupole - TQD) associado ao sistema UPLC e equipado com uma fonte de ionização de eletronebulização operando no modo positivo (eletrospray ionization - ESI+). Nitrogênio foi usado como gás de nebulização. As temperaturas da fonte e de

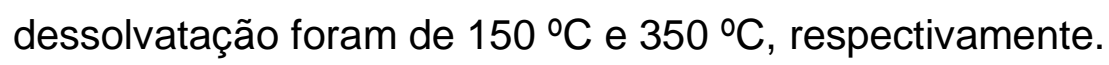

O íon precursor $536,6 \mathrm{~m} / \mathrm{z}$ bem como os fragmentos característicos de carotenoides $(444,8$ e $119,7 \mathrm{~m} / \mathrm{z})$ foram monitorados utilizando o monitoramento tipo MRM (multiple reaction monitoring) com voltagem do cone de $40 \mathrm{~V}$.

Como os carotenoides estudados apresentaram estruturas similares e, consequentemente, resultaram na formação dos mesmos fragmentos massa/carga $(\mathrm{m} / \mathrm{z})(444,8$ e $119,7 \mathrm{~m} / \mathrm{z})$, estes foram identificados por comparação do tempo de 
retenção dos padrões de carotenoides. Os dados foram analisados e tratados utilizando o software MassLynx (versão 4.1, Waters).

\subsubsection{Determinação do índice de retenção de solução aderida às fibras}

O índice de retenção, o qual se refere ao teor de solução extrato aderida à massa de sólidos inertes ( $\mathrm{kg}$ de solução aderida/kg de sólidos inertes), foi determinado logo após o processo de extração.

Para tanto, no caso dos experimentos em batelada, o filtro de papel contendo a fase rafinado foi removido do extrator, mantido suspenso, em repouso por 5 minutos para escoamento do líquido, e submetido a pesagem em balança de precisão para determinação da massa da fase rafinado e posterior realização de balanços de massa para estimativa do índice de retenção de solução.

Para a determinação do índice de retenção em experimentos em coluna, não houve um tempo de repouso do material sólido para escoamento do líquido, já que o esgotamento de solução da coluna de extração, adicionado ao tempo de retirada do sólido, equivaleram aos 5 minutos de drenagem descritos anteriormente. Desta forma, o sólido retirado da coluna com o auxílio de um bastão metálico foi coletado em um papel filtro e devidamente pesado.

\subsubsection{Determinação do teor de óleo residual na fase rafinado}

O teor residual de óleo de FPP presente na fase rafinado resultante do processo de extração foi determinado utilizando-se um sistema de extração com solvente à alta temperatura, segundo método oficial da AOCS Am 5-04 (2009). Foi utilizado hexano como solvente de extração e temperatura de $90^{\circ} \mathrm{C}$ durante uma hora. $\mathrm{O}$ teor de óleo residual nas amostras foi calculado a partir da Equação 21.

$$
\text { Óleo Residual }(\%)=\frac{(\text { Massa Inicial }- \text { Massa Final }) \times 100}{\text { Massa Inicial }}
$$




\subsubsection{Rendimento de extração de óleo}

O cálculo do rendimento relativo de extração de óleo de FPP, em porcentagem, foi calculado segundo a Equação 22, conforme sugerido por Scharlack et al. (2017).

Rendimento $(\%)=\left(\frac{\left(M_{F P P} \times \text { wóleo } F P P\right)-\left(M^{\prime} R A F \times w^{\prime} \text { óleoRAF }\right)}{\left(M_{F P P} \times \text { wóleoFPP }\right)}\right) \times 100$

Onde: $M_{F P P}=$ massa de fibra prensada de palma, em base seca $(\mathrm{g}) ; w_{\text {óleoFPP }}=$ fração mássica de óleo presente na fibra prensada de palma, em base seca; $M_{\text {RAF }}^{\prime}$ massa de rafinado em base livre de solvente $(\mathrm{g}) ; w^{\prime}$ óleoRAF = fração mássica de óleo presente na fase rafinado, em base livre de solvente $(\mathrm{g})$.

\subsubsection{Análise estatística}

Os valores médios dos resultados provenientes dos experimentos de extração foram comparados por análise de variância utilizando o teste de Duncan ao nível de 95 $\%$ de confiança (DUNCAN, 1955), com o auxílio do programa SAS® (Versão 9.3, SAS Institute Inc., EUA). 


\section{RESULTADOS E DISCUSSÃO}

\subsection{Caracterização da fibra prensada de palma}

Após o recebimento da FPP fresca esta foi submetida à secagem à $40{ }^{\circ} \mathrm{C}$, por 24 horas, segundo metodologia reportada por Cardenas-Toro et al. (2014). A umidade de $38 \pm 2 \%$ presente na FPP úmida foi próxima aos valores reportados por França (1999) e Lau et al. (2006) que obtiveram cerca de 30 a $45 \%$ de umidade.

A composição centesimal da FPP está apresentada na Tabela 6. De maneira geral, se percebe uma sutil diferença em relação à composição centesimal reportada por Kelly-Young et al. (2007) e Cardenas-Toro et al. (2014), especialmente no que diz respeito ao menor teor de fibras insolúveis e de proteínas, como pode ser visto na Tabela 7. Essas diferenças podem estar relacionadas às variações climáticas durante 0 cultivo da palmeira e à própria heterogeneidade da estrutura física da FPP, composta também por restos de espículas e sementes (denominada de palmiste).

Tabela 6 Composição centesimal da fibra prensada de palma após adequação da umidade.

\begin{tabular}{|c|c|}
\hline Componente & $\%$ em massa (média \pm desvio) \\
\hline Umidade $^{a}$ & $6,8 \pm 0,3$ \\
\hline Lipídeos $^{\text {b }}$ & $4,8 \pm 0,3$ \\
\hline Proteínas $^{\text {b.c }}$ & $10,34 \pm 0,01$ \\
\hline Cinzas $^{\mathrm{b}}$ & $3,53 \pm 0,05$ \\
\hline Fibras solúveis ${ }^{\mathrm{b}}$ & $1,3 \pm 0,5$ \\
\hline Fibras insolúveis & $81,3 \pm 0,5$ \\
\hline Carboidratos totais $^{d}$ & $-1 \pm 1$ \\
\hline
\end{tabular}

${ }^{a}$ Componente em base úmida. ${ }^{b}$ Componente em base seca. ${ }^{c}$ Teor de nitrogênio x 6,25. ${ }^{d}$ Determinado por diferença. Fonte: Própria autoria.

O conteúdo de lipídeos em massa, de 4,8 \pm 0,3\% (em base seca), é próximo ao conteúdo reportado por Choo et al. (1996), de 5-6 \% (em base seca). Quando este teor 
de lipídeos é comparado ao de outros coprodutos agroindustriais tais como farelo de arroz (20,4 \pm 0,7 \%, em massa seca) (CAPELLINI et al., 2017), torta de sementes de girassol (25,6 $\pm 0,2 \%$, em massa seca) (SCHARLACK et al., 2017), gérmen de milho $(10,74 \pm 0,05 \%$, em massa seca) (NAVARRO et al., 2016) e borra de café $(22,5 \pm 0,4$, em massa seca) (TODA, 2016) percebe-se que o conteúdo de lipídeos da FPP é relativamente baixo.

Tabela 7 Composição centesimal da fibra prensada de palma reportada na literatura.

\begin{tabular}{ccc}
\hline $\begin{array}{c}\text { Componente } \\
(\%, \text { em base seca) }\end{array}$ & Kelly-Young et al. (2007) ${ }^{\mathrm{a}}$ & Cardenas-Toro et al. (2014) $^{\mathrm{b}}$ \\
\hline Extrativos (totais) & 6,9 & - \\
Em água & - & $6,4 \pm 0,4$ \\
Em álcool & - & $3,7 \pm 0,2$ \\
\hline Proteínas & - & $6,3 \pm 0,1$ \\
Cinzas & 3,5 & $3,1 \pm 0,1$ \\
Lignina & 27,7 & $32,1 \pm 2,1$ \\
Hemicelulose & 33,9 & - \\
Celulose & 26,1 & - \\
Carboidratos & - & 48,6 \\
\hline
\end{tabular}

"Determinado por diferença.

Fonte: ${ }^{a}$ KELLY-YOUNG, T. L.; LEE, K. T.; MOHAMED, A. R.; BHATIA, S. Potential of hydrogen from oil palm biomass as a source of renewable energy wordwide. Energy Policy. v. 35, p. 5692-5701, 2007.

${ }^{\mathrm{b}}$ CARDENAS-TORO, F. P.; FORSTER-CARNEIRO, T.; ROSTAGNO, M. A.; PETENATE, A. J.; MAUGERI FILHO, F.; MEIRELES, M. A. A. Integrated supercritical fluid extraction and subcritical water hydrolysis for the recovery of bioactive compounds from pressed palm fiber. The Journal of Supercritical Fluids, v. 93, p. 42-48, 2014.

As peneiras Tyler utilizadas para a determinação da distribuição granulométrica e do tamanho de partículas permitem, de forma geral, a análise de partículas de 297 a $1680 \mu \mathrm{m}$, enquanto o equipamento por difração a laser possibilita a determinação do tamanho de partículas menores, na faixa de 0,25 a $350 \mu \mathrm{m}$.

O perfil heterogêneo das partículas de FPP triturada está apresentado na Figura 9, através da qual se pode observar uma maior porcentagem de partículas concentradas na faixa de 0 a $595 \mu \mathrm{m}$. Adicionalmente, os valores de massas retidas em cada peneira, a partir da análise de granulometria pelas peneiras Tyler, resultou em um 
expressivo conteúdo de massa de fundo, em torno de $33 \pm 4 \mathrm{~g}(49,6 \%)$, como apresentado na Tabela 8.

Deste modo, com o objetivo de averiguar a distribuição granulométrica das partículas com tamanho inferior a $297 \mu \mathrm{m}$ realizou-se a análise de difração a laser desta fração como se observa na Figura 10.

O valor do diâmetro médio das partículas de FPP foi calculado através da média ponderada simples do diâmetro médio pelas peneiras Tyler $\left(\mathrm{dm}_{\mathrm{ty}}\right)$ igual a $317 \pm 10 \mu \mathrm{m}$, e os fornecidos pela difração a laser $\left(\mathrm{dm}_{\mathrm{dl}}\right)$ iguais a $88 \pm 1$ e $172 \pm 26 \mu \mathrm{m}$, obtendo-se assim o valor do diâmetro médio das partículas presentes na amostra $\left(\mathrm{dm}_{\mathrm{p}}\right)$, sendo este igual $276 \pm 11 \mu \mathrm{m}$. Estes valores são próximos aos valores reportados por CardenasToro et al. (2014) que obtiveram FPP com granulometrias entre 180 a $1650 \mu \mathrm{m}$.

Figura 9 Distribuição granulométrica da fibra prensada de palma pelas peneiras Tyler.

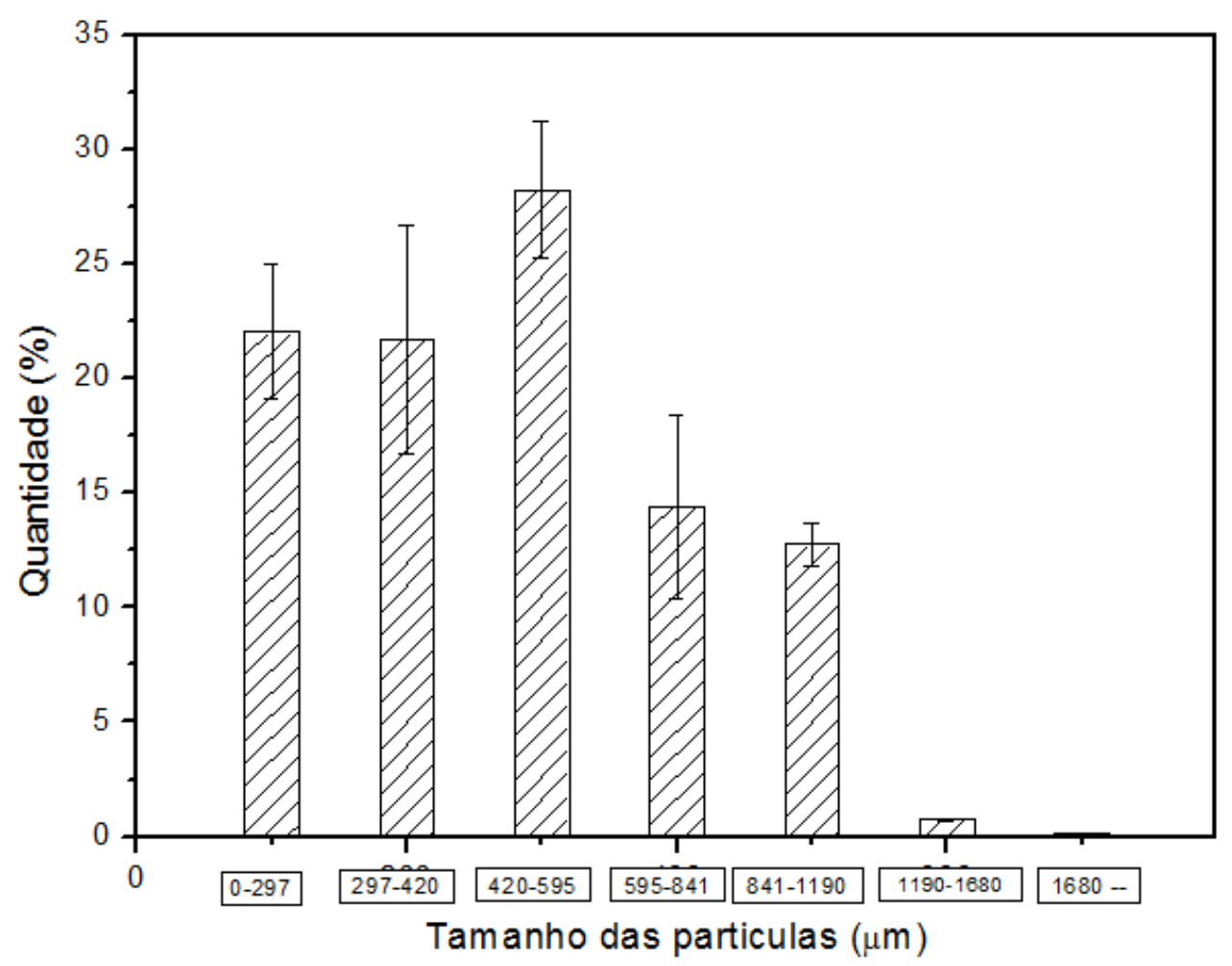

Fonte: Própria autoria. 
Tabela 8 Valores da distribuição granulométrica da fibra prensada de palma pelas peneiras Tyler.

\begin{tabular}{cccc}
\hline Mesh & Média da massa retida em cada peneira $(\mathbf{g})$ & $\mathbf{d}_{\mathbf{i}}{ }^{*}(\mathbf{m m})$ & $\mathbf{d}_{\mathbf{i}+1}{ }^{*}(\mathbf{m m})$ \\
\hline 8 & 0 & 2,280 & \\
10 & $0,16 \pm 0,05$ & 1,680 & 2,280 \\
14 & $1,12 \pm 0,04$ & 1,190 & 1,680 \\
20 & $19 \pm 2$ & 0,841 & 1,190 \\
28 & $22 \pm 6$ & 0,595 & 0,841 \\
35 & $42 \pm 5$ & 0,420 & 0,595 \\
48 & $33 \pm 7$ & 0,297 & 0,420 \\
Fundo & $33 \pm 4$ & & 0,297 \\
\hline
\end{tabular}

${ }^{*} d_{i}$ e $d_{i+1}$ referem-se às aberturas das peneiras. Fonte: Própria autoria.

Figura 10 Distribuição granulométrica da fibra prensada de palma por difração a laser.

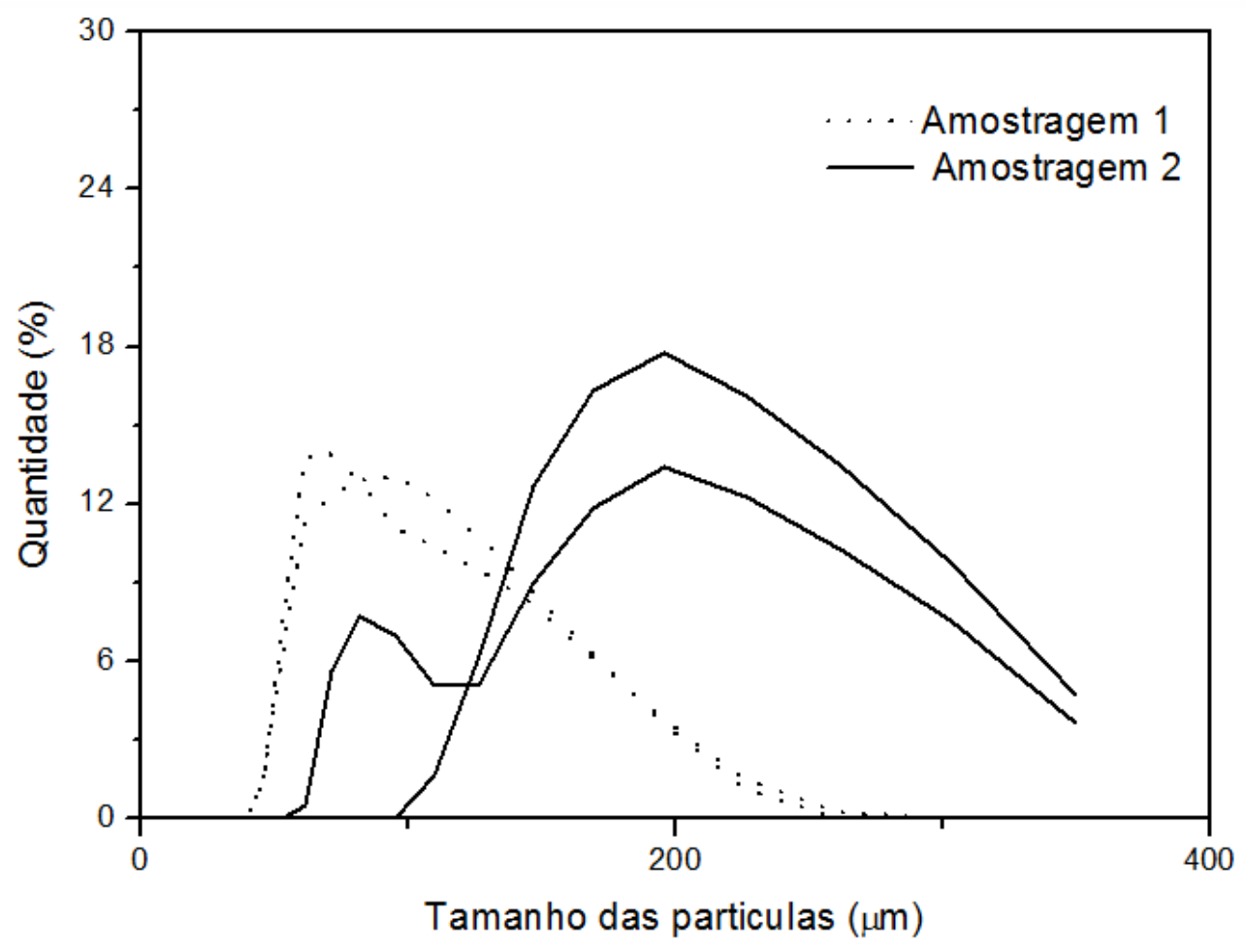

Fonte: Própria autoria. 
5.2 Determinação da composição das misturas entre solventes hidrocarbonetos e álcoois a partir do cálculo da distância soluto-solvente (Ra)

Para a determinação dos dados de extração sólido-líquido, a escolha das composições das misturas entre os solventes hidrocarbonetos (hexano, ciclohexano e heptano) e alcoólicos (etanol e isopropanol) foi realizada mediante a obtenção de valores de $\mathrm{Ra}$ iguais ao $\mathrm{Ra}$ calculado entre o soluto $\beta$-caroteno e os solventes hidrocarbonetos puros, pois estes apresentam parâmetros de solubilidade de Hansen (PSH) próximos aos do soluto de interesse, como foi descrito anteriormente no item 2.4. Os valores da $\mathrm{Ra}$ entre o soluto $\beta$-caroteno e os diferentes solventes e misturas de solventes estão apresentados na Tabela 9 e foram calculados segundo Equação 12.

Tabela 9 Cálculo da distância soluto-solvente $(\mathrm{Ra})$ entre o soluto $\beta$-caroteno e diferentes solventes e misturas de solventes, a $25^{\circ} \mathrm{C}$.

\begin{tabular}{cccc}
\hline \multicolumn{2}{c}{ Fração mássica } & Solventes & $\begin{array}{c}\text { Ra } \\
\boldsymbol{B} \text {-caroteno }\end{array}$ \\
\cline { 1 - 3 }$(\mathbf{1})$ & $\mathbf{( 2 )}$ & Etanol (1) & 19,7 \\
1 & 0 & Isopropanol (1) & 16,0 \\
1 & 0 & Hexano (1) & 5,3 \\
1 & 0 & Ciclohexano (1) & 2,1 \\
1 & 0 & Heptano (1) & 4,6 \\
\hline 0,79 & 0 & Hexano (1): Etanol (2) & 5,3 \\
0,73 & 0,21 & Hexano (1): Isopropanol (2) & 5,3 \\
\hline 0,85 & 0,27 & Ciclohexano (1): Etanol (2) & 2,1 \\
0,82 & 0,15 & Ciclohexano (1): Isopropanol (2) & 2,1 \\
\hline 0,81 & 0,18 & Heptano (1): Etanol (2) & 4,6 \\
0,76 & 0,19 & Heptano (1): Isopropanol (2) & 4,6 \\
\hline
\end{tabular}

Fonte: Própria autoria.

Os cálculos das composições das misturas de solventes hidrocarbonetos e álcoois resultaram na obtenção de maiores teores de isopropanol do que etanol, uma vez que este último possui valores de $\mathrm{PSH}$ levemente superiores aos $\mathrm{PSH}$ do isopropanol, o que permite inferir que a solubilidade de $\beta$-caroteno em isopropanol é 
levemente superior à solubilidade deste soluto em etanol. Por outro lado, o solvente ciclohexano apresentou a menor Ra denotando sua habilidade superior em solubilizar $\beta$-caroteno, quando comparado aos demais solventes hidrocarbonetos.

Estes solventes e misturas de solventes foram utilizados nos experimentos de extração sólido-líquido a fim de avaliar os seus impactos na obtenção de um elevado rendimento de óleo de fibra prensada de palma rico em carotenoides.

\subsection{Estudo do processo de extração de óleo de FPP em extrator em batelada}

A análise estatística dos valores médios de conteúdo de água na fase extrato referentes aos experimentos de extração com solventes puros e misturas de solventes é apresentada na Tabela 10. Estas comparações foram realizadas utilizando-se o Teste de Duncan, ao nível de $95 \%$ de confiança.

Tabela 10 Teor de água (\%, em massa) das fases extrato provenientes das extrações sólido-líquido em batelada

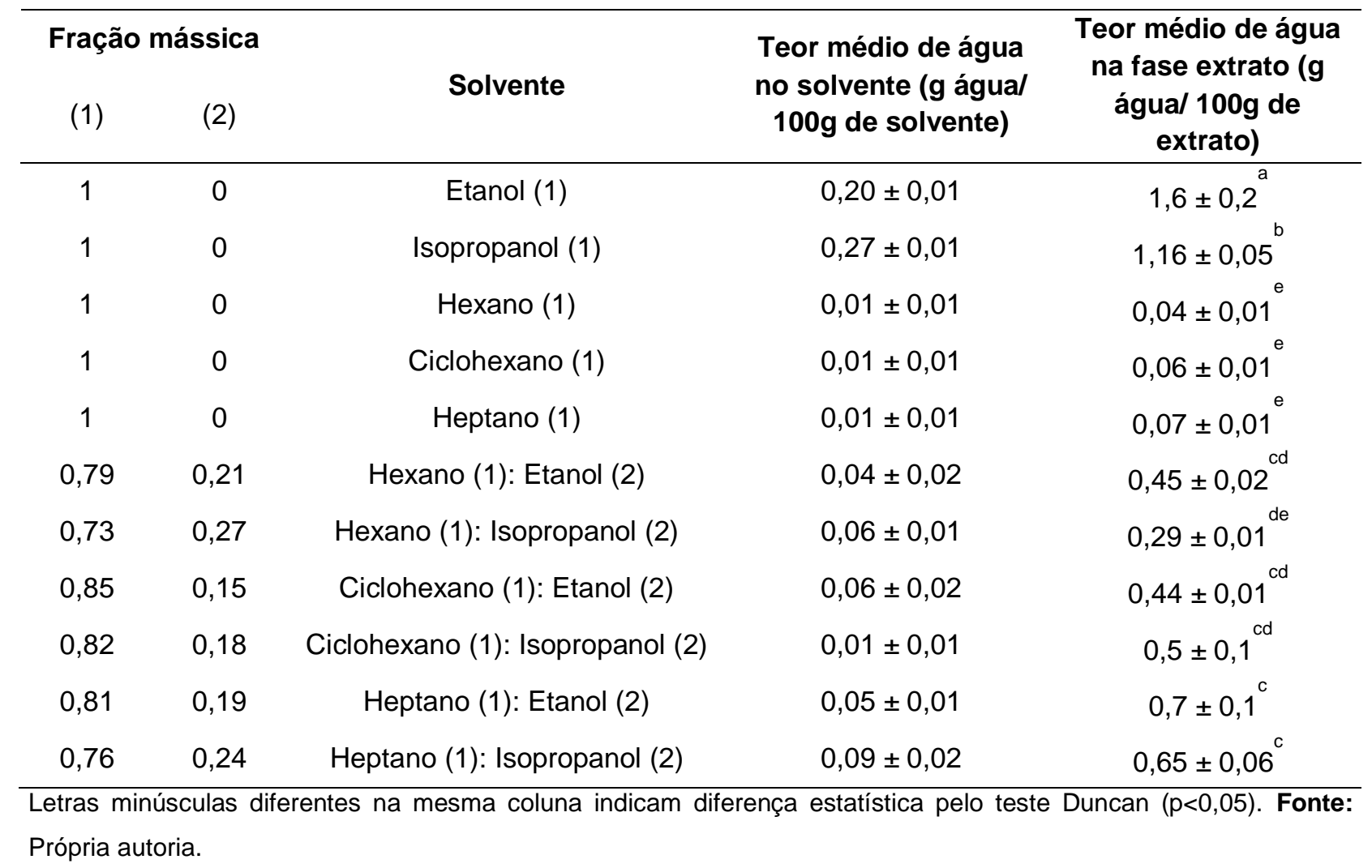


De fato, a matéria-prima, após a secagem inicial, permaneceu com um conteúdo baixo de umidade, em torno de $6 \%$. Este conteúdo de água transferiu-se para a fase extrato, principalmente, devido à utilização dos solventes alcoólicos, etanol e isopropanol.

Capellini (2013) analisou a transferência de água para a fase extrato em experimentos de extração de óleo de farelo de arroz utilizando solventes alcoólicos hidratados ou não. De fato, foram obtidos valores de teor de água na fase extrato muito próximos aos obtidos neste trabalho, com 1,6 \pm 0,4 \% (em massa) para etanol e $1,2 \pm 0,2 \%$ (em massa) para isopropanol.

Ademais, em outros trabalhos de extração de óleos vegetais, utilizando etanol e isopropanol, o fenômeno de hidratação da fase extrato foi observado, como por exemplo, para a massa prensada de sementes de girassol (SCHARLACK, 2015), borra de café (TODA, 2016) e gérmen de milho (NAVARRO, 2016). Vale ressaltar que o conteúdo de água extraído da FPP pelo etanol foi maior que o extraído por isopropanol, em todos estes estudos e sendo estes resultados de acordo com este trabalho.

Neste trabalho, os valores das constantes dielétricas (Di) foram calculados pela equação proposta por Wohlfarth (2014) para os solventes puros (etanol, isopropanol, hexano, ciclohexano e heptano), e segundo equação proposta por Tir et al. (2012) para as misturas entre os solventes hidrocarbonetos e álcoois. Os resultados calculados para a constante dielétrica ( $\mathrm{Di}$ ) em diferentes temperaturas são apresentados na Tabela 11.

A Tabela 11 mostra que os valores de Di calculados para os solventes alcoólicos foram consideravelmente superiores aos valores obtidos para os solventes hidrocarbonetos, o que permite afirmar que os solventes alcóolicos, etanol e isopropanol, são mais polares que os solventes hidrocarbonetos avaliados (hexano, heptano e ciclohexano). Pode-se observar também, que o solvente etanol apresentou os maiores valores de Di quando comparados a todos os solventes empregados. 
No caso dos solventes hidrocarbonetos, o solvente hexano destacou-se com o menor valor de $\mathrm{Di}$, sendo levemente inferior aos valores obtidos para heptano e ciclohexano demonstrando, portanto, sua menor polaridade. 
Tabela 11 Constantes dielétricas ( $\mathrm{Di}$ ) dos solventes puros e misturas de solventes utilizados nos experimentos de extração sólido-líquido.

\begin{tabular}{|c|c|c|c|c|c|c|c|c|c|}
\hline \multirow[t]{2}{*}{ Solventes } & \multirow[t]{2}{*}{ Fração mássica } & \multicolumn{8}{|c|}{$\begin{array}{c}\text { Constante Dielétrica (Di) } \\
\text { Temperatura }\left({ }^{\circ} \mathrm{C}\right)\end{array}$} \\
\hline & & 25 & 30 & 35 & 40 & 45 & 50 & 55 & 60 \\
\hline Etanol (1) & 1 & 24,80 & 24,23 & 23,69 & 23,17 & 22,68 & 22,21 & 21,77 & 21,34 \\
\hline Isopropanol (1) & 1 & 19,26 & 18,48 & 17,71 & 16,97 & 16,25 & 15,54 & 14,86 & 14,20 \\
\hline Hexano (1) & 1 & 1,88 & 1,88 & 1,87 & 1,86 & 1,85 & 1,85 & 1,84 & 1,83 \\
\hline Ciclohexano (1) & 1 & 2,02 & 2,01 & 2,00 & 1,99 & 1,99 & 1,98 & 1,97 & 1,96 \\
\hline Heptano (1) & 1 & 1,91 & 1,90 & 1,90 & 1,89 & 1,88 & 1,87 & 1,87 & 1,86 \\
\hline \multirow{4}{*}{$\begin{array}{l}\text { Hexano (1): } \\
\text { Etanol (2) }\end{array}$} & (1) $0,95:$ : (2) 0,05 & 3,03 & 2,99 & 2,96 & 2,92 & 2,89 & 2,86 & 2,83 & 2,80 \\
\hline & (1) $0,90:$ (2) 0,10 & 4,17 & 4,11 & 4,05 & 3,99 & 3,94 & 3,88 & 3,83 & 3,78 \\
\hline & (1) $0,85:$ : (2) 0,15 & 5,32 & 5,23 & 5,14 & 5,06 & 4,98 & 4,90 & 4,83 & 4,76 \\
\hline & (1) $0,80:(2) 0,20$ & 6,46 & 6,34 & 6,23 & 6,12 & 6,02 & 5,92 & 5,82 & 5,73 \\
\hline \multirow{5}{*}{$\begin{array}{l}\text { Hexano (1): } \\
\text { Isopropanol (2) }\end{array}$} & (1) $0,95:$ : (2) 0,05 & 2,76 & 2,71 & 2,66 & 2,62 & 2,58 & 2,53 & 2,49 & 2,45 \\
\hline & (1) 0,90: (2) 0,10 & 3,62 & 3,54 & 3,45 & 3,37 & 3,29 & 3,22 & 3,14 & 3,07 \\
\hline & (1) $0,85:$ : (2) 0,15 & 4,49 & 4,37 & 4,25 & 4,13 & 4,02 & 3,90 & 3,80 & 3,69 \\
\hline & (1) $0,80:(2) 0,20$ & 5,36 & 5,20 & 5,04 & 4,88 & 4,73 & 4,59 & 4,44 & 4,30 \\
\hline & (1) $0,75:$ (2) 0,25 & 6,23 & 6,02 & 5,83 & 5,64 & 5,45 & 5,27 & 5,09 & 4,92 \\
\hline \multirow{3}{*}{$\begin{array}{c}\text { Ciclohexano (1): } \\
\text { Etanol (2) }\end{array}$} & (1) $0,95:$ : (2) 0,05 & 3,16 & 3,13 & 3,09 & 3,06 & 3,02 & 2,99 & 2,96 & 2,94 \\
\hline & (1) $0,90:$ (2) 0,10 & 4,29 & 4,23 & 4,17 & 4,11 & 4,05 & 4,00 & 3,95 & 3,90 \\
\hline & (1) $0,85:$ : (2) 0,15 & 5,44 & 5,35 & 5,26 & 5,18 & 5,09 & 5,02 & 4,94 & 4,87 \\
\hline
\end{tabular}


(continuação)

\begin{tabular}{|c|c|c|c|c|c|c|c|c|c|}
\hline \multirow[t]{2}{*}{ Solventes } & \multirow{2}{*}{ Fração mássica } & \multicolumn{8}{|c|}{$\begin{array}{c}\text { Constante Dielétrica (Di) } \\
\text { Temperatura }\left({ }^{\circ} \mathrm{C}\right) \\
\end{array}$} \\
\hline & & 25 & 30 & 35 & 40 & 45 & 50 & 55 & 60 \\
\hline \multirow{3}{*}{$\begin{array}{l}\text { Ciclohexano (1): } \\
\text { Isopropanol (2) }\end{array}$} & (1) 0,95: (2) 0,05 & 2,88 & 2,84 & 2,79 & 2,75 & 2,70 & 2,66 & 2,62 & 2,58 \\
\hline & (1) $0,90:$ (2) 0,10 & 3,76 & 3,68 & 3,59 & 3,51 & 3,43 & 3,35 & 3,27 & 3,20 \\
\hline & (1) $0,85:(2) 0,15$ & 4,60 & 4,48 & 4,36 & 4,24 & 4,12 & 4,01 & 3,90 & 3,80 \\
\hline \multirow{4}{*}{$\begin{array}{l}\text { Heptano (1): } \\
\text { Etanol (2) }\end{array}$} & (1) 0,95: (2) 0,05 & 3,06 & 3,02 & 2,99 & 2,95 & 2,92 & 2,89 & 2,86 & 2,83 \\
\hline & (1) $0,90:$ (2) 0,10 & 4,21 & 4,14 & 4,08 & 4,02 & 3,97 & 3,91 & 3,86 & 3,81 \\
\hline & (1) $0,85:$ : (2) 0,15 & 5,36 & 5,26 & 5,18 & 5,09 & 5,01 & 4,94 & 4,86 & 4,79 \\
\hline & (1) $0,80:(2) 0,20$ & 6,49 & 6,37 & 6,25 & 6,14 & 6,04 & 5,94 & 5,85 & 5,75 \\
\hline \multirow{5}{*}{$\begin{array}{l}\text { Heptano (1): Isopropanol } \\
\text { (2) }\end{array}$} & (1) $0,95:$ : (2) 0,05 & 2,79 & 2,74 & 2,70 & 2,65 & 2,61 & 2,57 & 2,52 & 2,48 \\
\hline & (1) $0,90:$ (2) 0,10 & 3,65 & 3,56 & 3,48 & 3,40 & 3,32 & 3,24 & 3,17 & 3,10 \\
\hline & (1) $0,85:$ (2) 0,15 & 4,51 & 4,39 & 4,27 & 4,15 & 4,04 & 3,92 & 3,82 & 3,71 \\
\hline & (1) $0,80:(2) 0,20$ & 5,38 & 5,22 & 5,06 & 4,90 & 4,75 & 4,61 & 4,46 & 4,33 \\
\hline & (1) $0,75:$ : (2) 0,25 & 6,25 & 6,05 & 5,85 & 5,66 & 5,47 & 5,29 & 5,11 & 4,94 \\
\hline
\end{tabular}

Fonte: Própria autoria. 
Para as misturas de solventes estudadas, o acréscimo de solvente alcoólico ao solvente hidrocarboneto resultou no aumento dos valores de $\mathrm{Di}$, porém esses valores ainda mantiveram-se baixos quando comparados aos valores de $\mathrm{Di}$ dos solventes alcoólicos puros. A adição de etanol aos solventes hexano, ciclohexano e heptano resultou em sutil acréscimo aos valores de $\mathrm{Di}$, quando comparado ao acréscimo de isopropanol a estes solventes hidrocarbonetos. Dessa forma, pode-se afirmar que as misturas de hexano, ciclohexano e heptano com isopropanol resultaram em misturas com menor polaridade. Ainda, observa-se na Tabela 11 que o aumento da temperatura resulta em decréscimo nos valores de Di observados para todos os solventes puros e misturas de solventes, o que também foi observado por Bosch et al. (1996).

O comportamento da transferência de água da FPP para a fase extrato em função da polaridade do solvente empregado, expressa pela constante dielétrica, pode ser observado na Figura 11.

Figura 11 Transferência de água (\%) para a fase extrato em função da constante dielétrica.

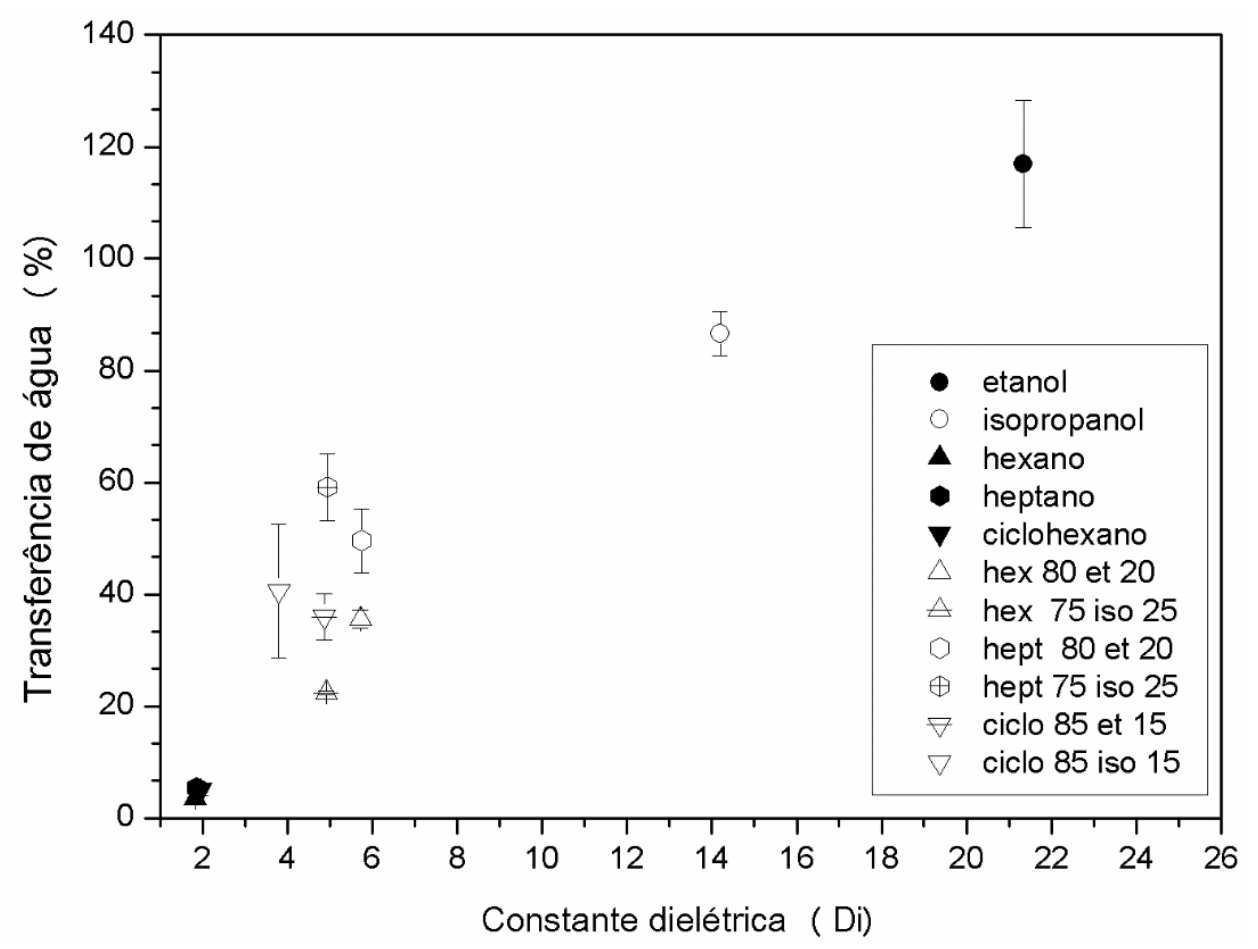

Fonte: Própria autoria. 
Nesta figura percebe-se que a transferência de água para a fase extrato apresentou um comportamento crescente em relação ao aumento da Di dos solventes e misturas de solventes avaliadas. Dessa forma, os solventes hidrocarbonetos puros apresentaram os menores valores de constante dielétrica, denotando assim sua menor afinidade química pela água e, consequentemente, a menor transferência de água para a fase extrato. Já a adição de 15 a $25 \%$, em massa, de solvente alcoólico aos solventes hidrocarbonetos, resultou no aumento da transferência de água para a fase extrato, mas estes valores ainda foram menores que os valores obtidos utilizando os solventes alcoólicos puros, isopropanol e etanol, os quais apresentaram as maiores constantes dielétricas.

Os resultados de rendimento relativo de extração de óleo de FPP, expressos em porcentagem, relativo às extrações utilizando-se solventes puros e misturas de solventes são apresentados na Figura 12.

Figura 12 Rendimento relativo (\%) de extração de óleo de FPP utilizando solventes puros e misturas para extrações em batelada.

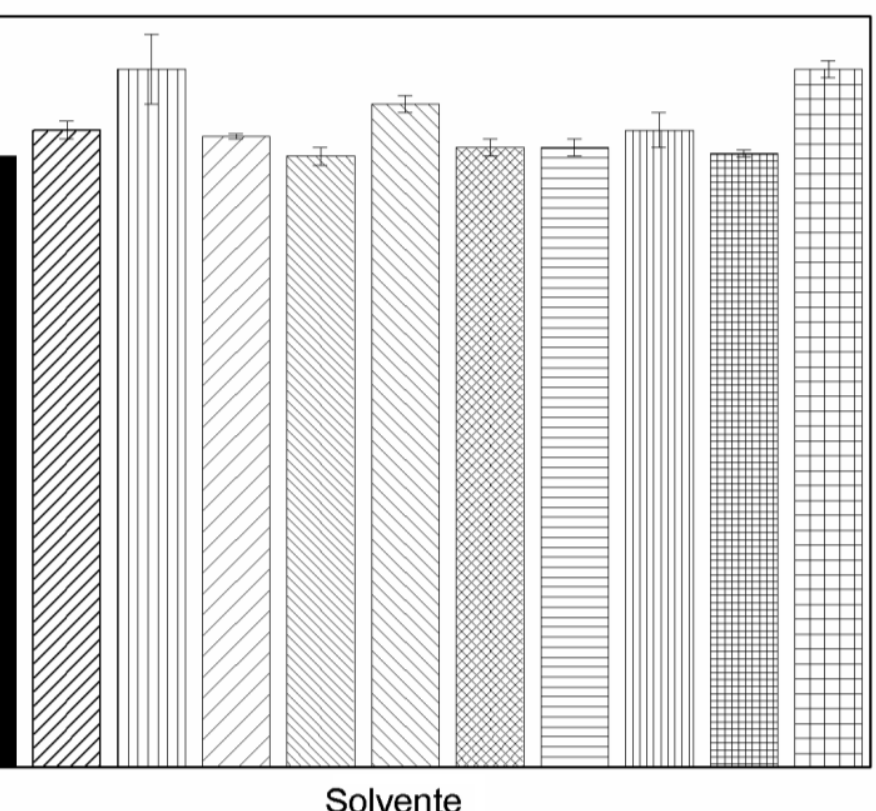

Fonte: Própria autoria. 
A análise estatística dos valores médios de rendimento relativo de extração de óleo de FPP, teor de sólidos solúveis (\%) e teor de óleo residual (\%), utilizando os solventes puros e as misturas é apresentada na Tabela 12. Estas comparações foram realizadas utilizando-se o Teste de Duncan, ao nível de $95 \%$ de confiança.

Tabela 12 Rendimento relativo (\%) de extração de óleo de fibra prensada de palma em extrator em batelada utilizando solventes puros e misturas de solventes.

\begin{tabular}{|c|c|c|c|c|c|}
\hline \multicolumn{2}{|c|}{$\begin{array}{l}\text { Fração } \\
\text { mássica }\end{array}$} & \multirow{2}{*}{ Solvente } & \multirow{2}{*}{$\begin{array}{c}\text { Rendimento (\%) } \\
\text { (média } \pm \\
\text { desvio) }\end{array}$} & \multirow{2}{*}{$\begin{array}{l}\text { Teor de sólidos } \\
\text { solúveis }(\%)^{1} \\
\text { (média } \pm \text { desvio) }\end{array}$} & \multirow{2}{*}{$\begin{array}{c}\text { Teor de óleo } \\
\text { residual (\%) } \\
\text { (média } \pm \\
\text { desvio) }^{2}\end{array}$} \\
\hline (1) & (2) & & & & \\
\hline 1 & 0 & Etanol (1) & $70 \pm 2^{c}$ & $1,16 \pm 0,02^{a}$ & $1,50 \pm 0,09^{a}$ \\
\hline 1 & 0 & Isopropanol (1) & $73 \pm 1^{\mathrm{bc}}$ & $1,02 \pm 0,04^{a b c}$ & $1,34 \pm 0,05^{\mathrm{ab}}$ \\
\hline 1 & 0 & Hexano (1) & $80 \pm 4^{a}$ & $0,9 \pm 0,1^{\text {cde }}$ & $1,06 \pm 0,02^{c}$ \\
\hline 1 & 0 & Ciclohexano (1) & $72,3 \pm 0,3^{b c}$ & $0,9 \pm 0,1^{\text {cde }}$ & $1,3 \pm 0,1^{\mathrm{b}}$ \\
\hline 1 & 0 & Heptano (1) & $70 \pm 1^{c}$ & $0,8 \pm 0,2^{\text {et }}$ & $1,47 \pm 0,08^{a}$ \\
\hline 0,79 & 0,21 & $\begin{array}{c}\text { Hexano (1): } \\
\text { Etanol (2) } \\
\end{array}$ & $76 \pm 1^{a b}$ & $1,09 \pm 0,02^{a b}$ & $1,1 \pm 0,1^{c}$ \\
\hline 0,73 & 0,27 & $\begin{array}{c}\text { Hexano (1): } \\
\text { Isopropanol (2) }\end{array}$ & $70,6 \pm 0,6^{c}$ & $1,02 \pm 0,05^{a b c}$ & $1,39 \pm 0,03^{a b}$ \\
\hline 0,85 & 0,15 & $\begin{array}{c}\text { Ciclohexano (1): } \\
\text { Etanol (2) }\end{array}$ & $71 \pm 1^{c}$ & $0,8 \pm 0,1^{\mathrm{ed}}$ & $1,3 \pm 0,1^{b}$ \\
\hline 0,82 & 0,18 & $\begin{array}{l}\text { Ciclohexano (1): } \\
\text { Isopropanol (2) }\end{array}$ & $73 \pm 2^{b c}$ & $0,67 \pm 0,01^{f}$ & $1,3 \pm 0,1^{b}$ \\
\hline 0,81 & 0,19 & $\begin{array}{l}\text { Heptano (1): } \\
\text { Etanol (2) }\end{array}$ & $70,3 \pm 0,4^{c}$ & $0,98 \pm 0,02^{b c d}$ & $1,36 \pm 0,04^{a b}$ \\
\hline 0,76 & 0,24 & $\begin{array}{l}\text { Heptano (1): } \\
\text { Isopropanol (2) }\end{array}$ & $80 \pm 1^{a}$ & $0,8 \pm 0,1^{\text {ef }}$ & $0,96 \pm 0,02^{c}$ \\
\hline
\end{tabular}

${ }^{4}$ Determinado na fase extrato. ${ }^{2}$ Determinado na fase rafinado. Letras minúsculas diferentes na mesma coluna indicam diferença estatística pelo teste Duncan $(p<0,05)$. Fonte: Própria autoria.

Com base na análise estatística, pode-se inferir que o solvente hexano e a mistura compreendida por heptano e isopropanol apresentaram as maiores capacidade de extração de óleo de FPP, com rendimento relativo médio óleo de 80 \%. Este resultado foi superior ao obtido por Gandhi et al. (2003), os quais obtiveram um rendimento de 
extração de óleo de soja utilizando a mistura de heptano e etanol (52:48, em volume), na razão mássica solvente:sólido de 2:1 e temperatura de $70 \stackrel{\circ}{\circ}$ por 4 horas, de $72 \%$.

Os demais solventes e misturas de solventes empregados apresentaram capacidade de extração de óleo levemente inferior, entre 70 a 73 \%.

No caso da mistura de solventes alcoólicos e hidrocarbonetos, a adição de etanol ao hexano resultou em um sutil acréscimo no rendimento de extração de óleo quando comparado ao rendimento obtido utilizando etanol puro.

Wan et al. (1995a), utilizando razão mássica solvente:sólido de 5,5:1 na temperatura de $55 \stackrel{\circ}{ } \mathrm{C}$ relataram, após 10 minutos de extração, a obtenção de resultados superiores de extração para óleo de algodão, de 89,4 e 95,9 \% utilizando ciclohexano e heptano, respectivamente.

A avaliação do emprego de solventes alcoólicos na extração de óleo de farelo de arroz (CAPELLINI, 2013) e óleo de gérmen de milho (NAVARRO, 2016), na razão sólido:solvente, de $1: 3$, a $60^{\circ} \mathrm{C}$, resultou em rendimentos relativos de extração próximos a $80 \%$ com o uso de isopropanol, e cerca de 70 a $65 \%$ (em massa) com etanol. Ademais, Li et al. (2014) destacam a maior extração de óleo de sementes de colza com o uso de isopropanol em comparação com o etanol, em extração do tipo Sohxlet. Este aumento no rendimento de extração de óleo vegetal com o emprego de isopropanol em relação ao etanol, a $60{ }^{\circ} \mathrm{C}$, também foi reportado em outros trabalhos da literatura (TODA, 2016; SCHARLACK, 2015), porém não foi observado neste trabalho.

Toda et al. (2016) reportam que o mecanismo de extração sólido-líquido envolve, além da solubilização do óleo, uma sequência de eventos de transferência de massa. Estas etapas referem-se à transferência do solvente sobre a superfície sólida, a penetração do solvente através da parede celular da matriz oleaginosa, a difusão do solvente pelo interior da matriz até alcançar os corpos lipídicos, a difusão da solução composta pelos lipídeos solubilizados e solvente para a superfície da matriz sólida e, por fim, a transferência desta solução a partir da superfície para o seio da solução.

Dessa forma, as propriedades químicas e físicas dos solventes empregados nos experimentos de extração sólido-líquido, tais como a polaridade, expressa pela constante 
dielétrica, massa específica e viscosidade dinâmica, influenciam diretamente nas etapas de transferência de massa.

Por exemplo, Tir et al. (2012) avaliaram o emprego de diversos solventes orgânicos (hexano, acetona, diclorometano, etanol e isopropanol) e misturas compreendidas por hexano e isopropanol e clorofórmio e metanol no rendimento de extração de óleo de semente de gergelim. Os autores reportam que a polaridade do solvente, medida através da constante dielétrica, exerce importante papel na determinação das interações soluto e solvente e, consequentemente, impactam o rendimento de extração de óleo.

Os dados de massa específica e viscosidade dinâmica determinados para os solventes puros (alcoólicos e hidrocarbonetos) e misturas de solventes, em diferentes temperaturas, estão apresentadas nas Figuras de 13 a 24.

Os valores de massa específica dos solventes puros, determinados na faixa entre 298,15 a $313,15 \mathrm{~K}$, (de 25 a $40^{\circ} \mathrm{C}$ ) para etanol, isopropanol, hexano, ciclohexano e heptano, variaram entre $0,7852 \pm 0,0005$ a $0,77200 \pm 0,00001 \mathrm{~g} / \mathrm{cm}^{3} ; 0,7814 \pm 0,0009$ a $0,7683 \pm 0,0006 \mathrm{~g} / \mathrm{cm}^{3} ; 0,65993 \pm 0,00005$ a $0,6458 \pm 0,0001 \mathrm{~g} / \mathrm{cm}^{3} ; 0,7734 \pm 0,0005 \mathrm{a}$ $0,7592 \pm 0,0002 \mathrm{~g} / \mathrm{cm}^{3}$ e $0,67913 \pm 0,00005$ a $0,6664 \pm 0,0001 \mathrm{~g} / \mathrm{cm}^{3}$, respectivamente Já a adição de solvente alcoólico aos solventes hidrocarbonetos, hexano e heptano, resultou em sutil acréscimo nos valores de massa específica obtidos.

Como esperado, observou-se que o aumento da temperatura resultou na diminuição dos valores de massa específica para todos os solventes e misturas de solventes estudadas.

Ademais, o solvente que apresenta os menores valores de massa específica foi o hexano e suas respectivas misturas com etanol e isopropanol.

A análise comparativa entre o emprego dos solventes hexano e isopropanol e a obtenção de maiores rendimentos de extração de óleo de farinha de jojoba, estudada por Wlsniak et al. (1987), resultou em maiores rendimentos de extração de óleo vegetal com o uso do solvente com menor viscosidade. 
Figura 13 Massas específicas $\left(\mathrm{g} / \mathrm{cm}^{3}\right)$ do hexano e etanol e suas respectivas misturas em função da temperatura.

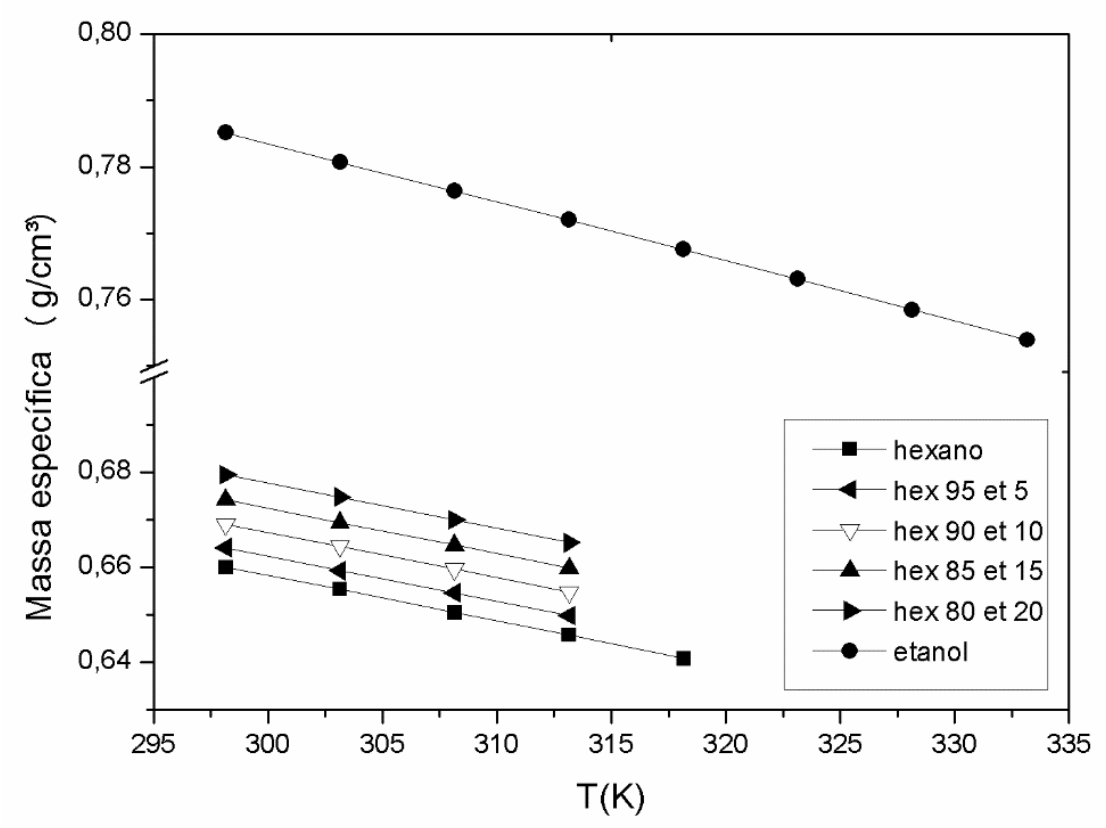

Fonte: Própria autoria.
Figura 14 Massas específicas $\left(\mathrm{g} / \mathrm{cm}^{3}\right)$ do hexano e isopropanol e suas respectivas misturas em função da temperatura.

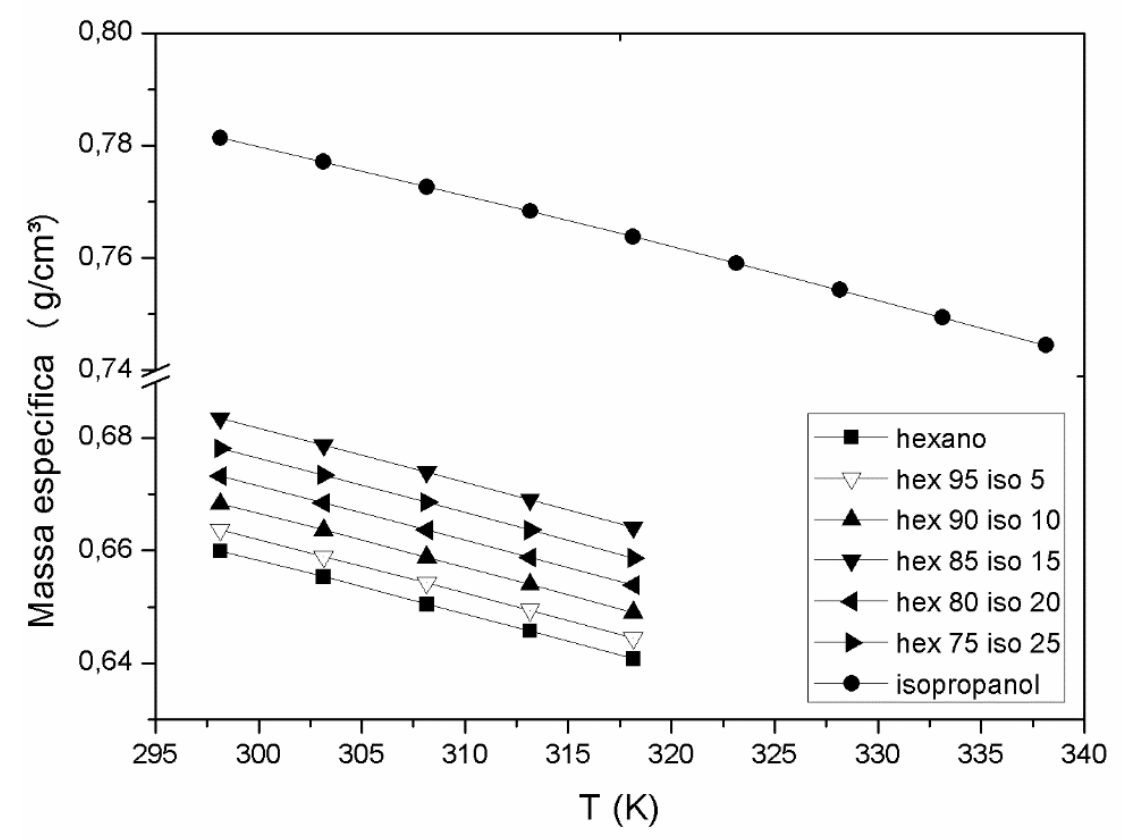

Fonte: Própria autoria. 
Figura 15 Massas específicas $\left(\mathrm{g} / \mathrm{cm}^{3}\right)$ do ciclohexano e etanol e suas respectivas misturas em função da temperatura.

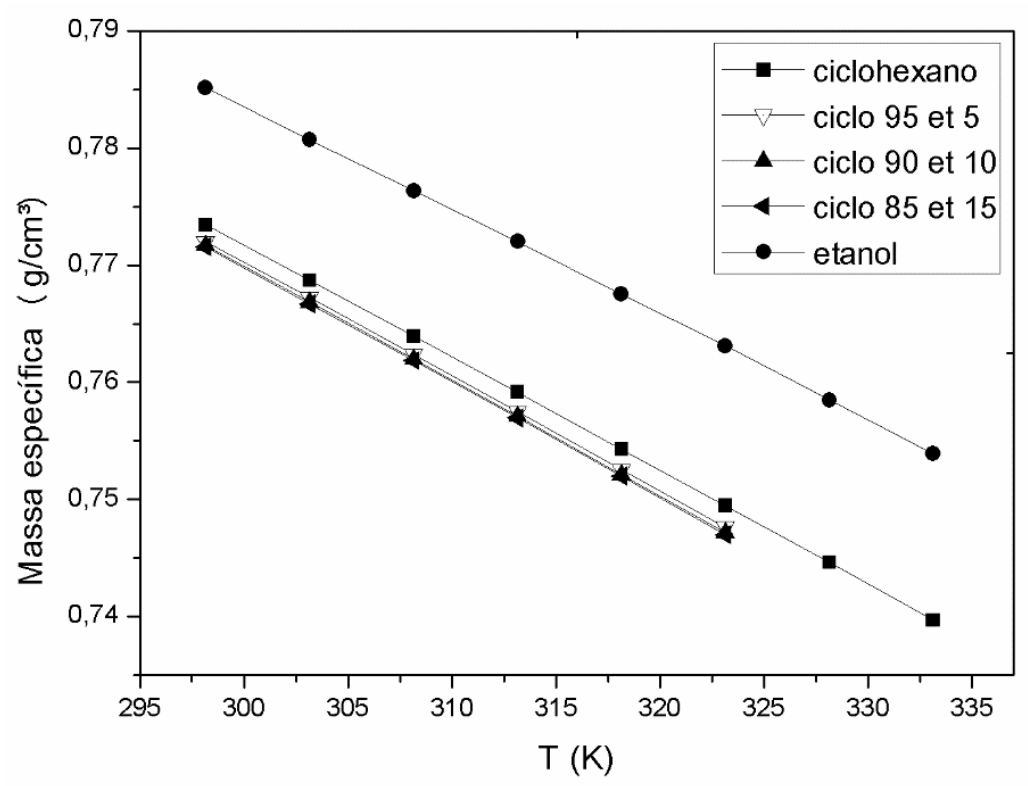

Fonte: Própria autoria.
Figura 16 Massas específicas $\left(\mathrm{g} / \mathrm{cm}^{3}\right)$ do ciclohexano e isopropanol e suas respectivas misturas em função da temperatura.

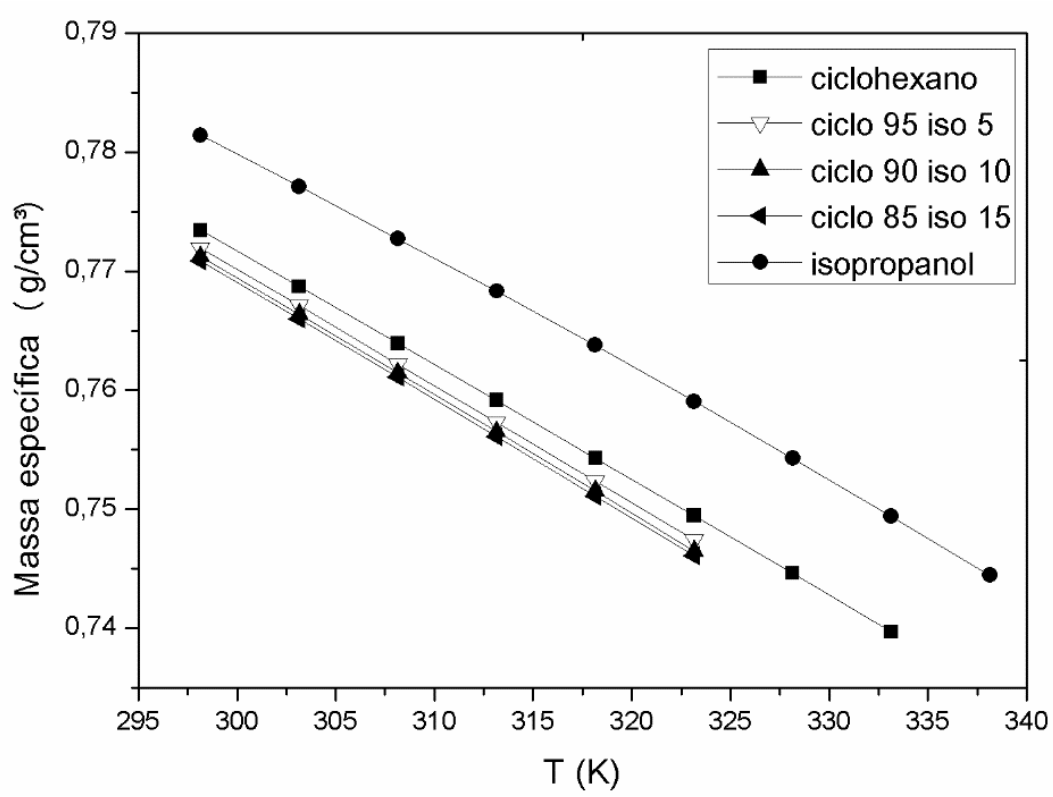

Fonte: Própria autoria. 
Figura 17 Massas específicas $\left(\mathrm{g} / \mathrm{cm}^{3}\right)$ do heptano e etanol e suas respectivas misturas em função da temperatura.

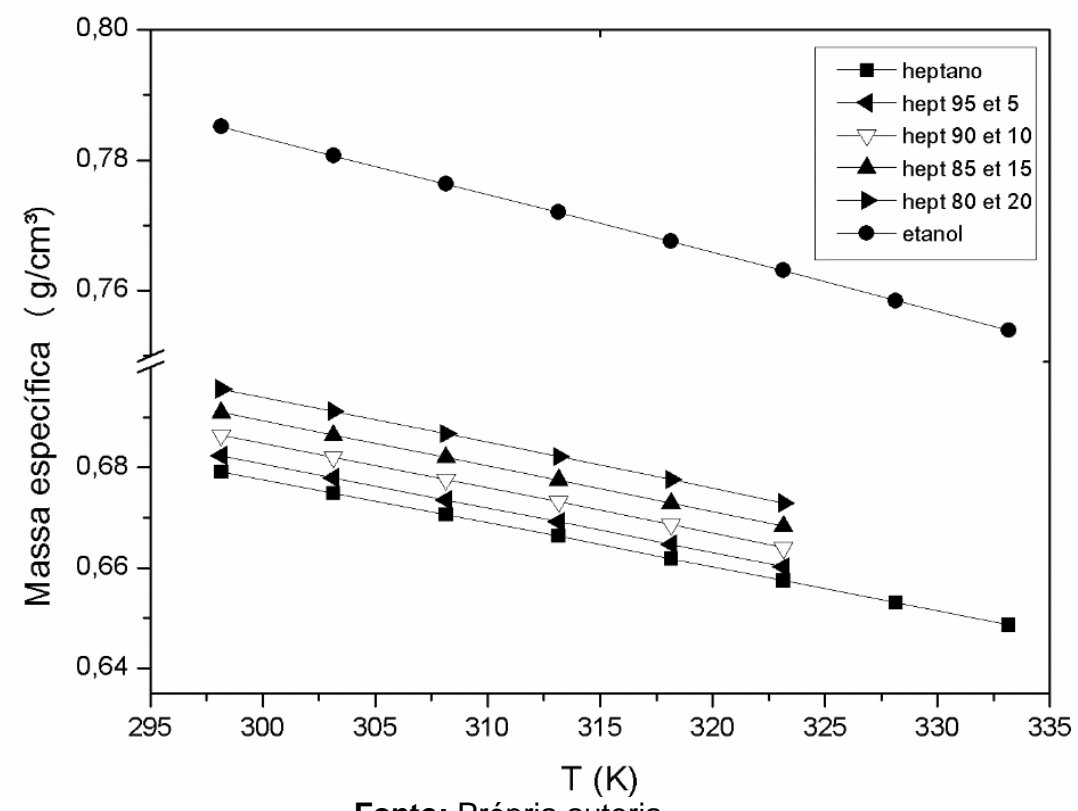

Fonte: Própria autoria.
Figura 18 Massas específicas $\left(\mathrm{g} / \mathrm{cm}^{3}\right)$ do heptano e isopropanol e suas respectivas misturas em função da temperatura.

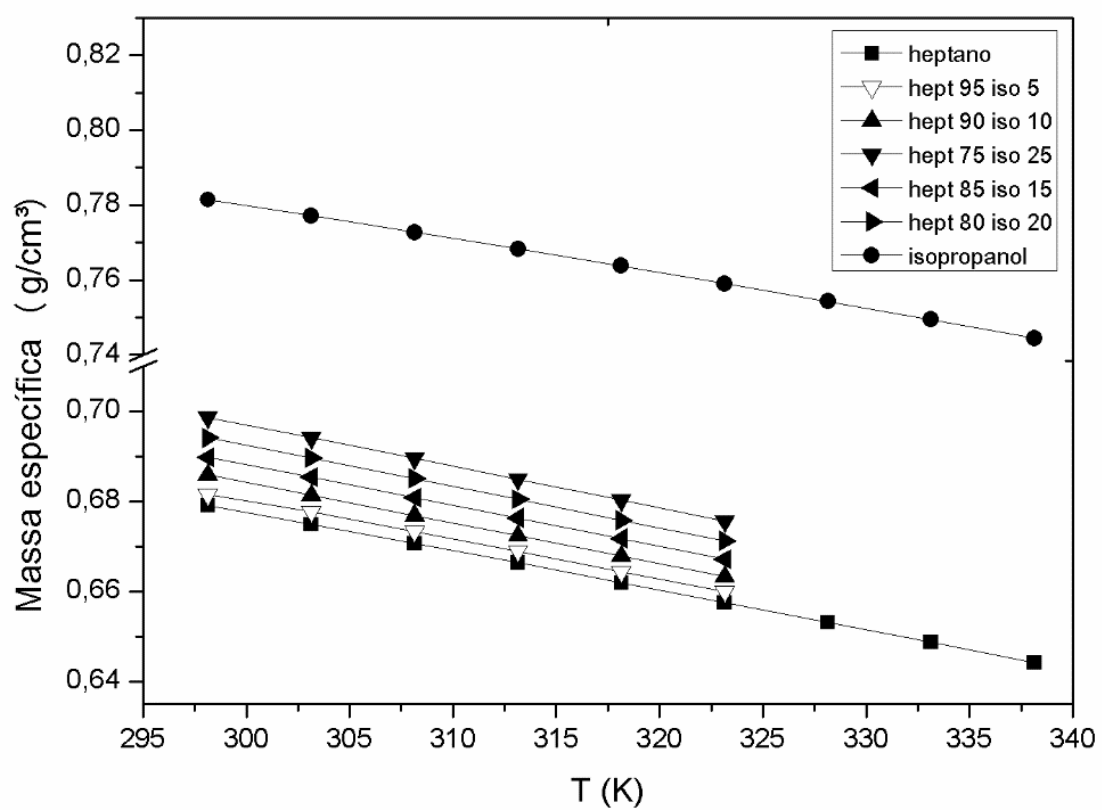

Fonte: Própria autoria. 
Figura 19 Viscosidades dinâmicas (mPa.s) do hexano e etanol e suas respectivas misturas em função da temperatura.

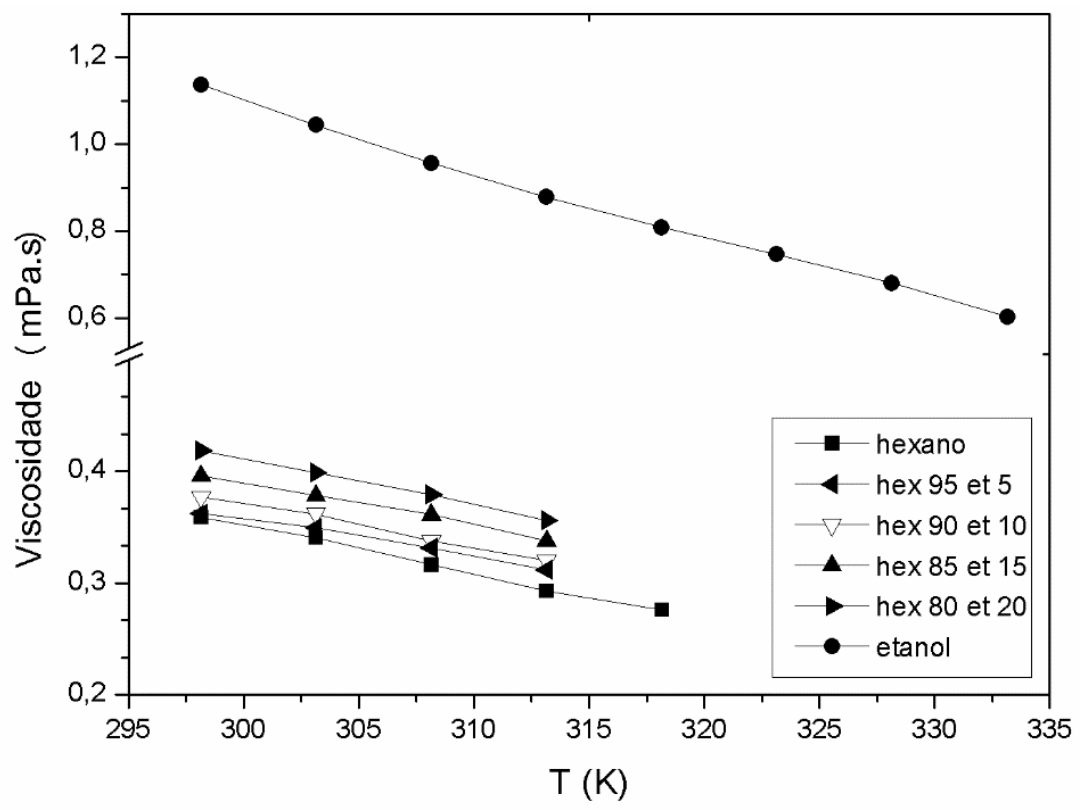

Fonte: Própria autoria.
Figura 20 Viscosidades dinâmicas (mPa.s) do hexano e isopropanol e suas respectivas misturas em função da temperatura.

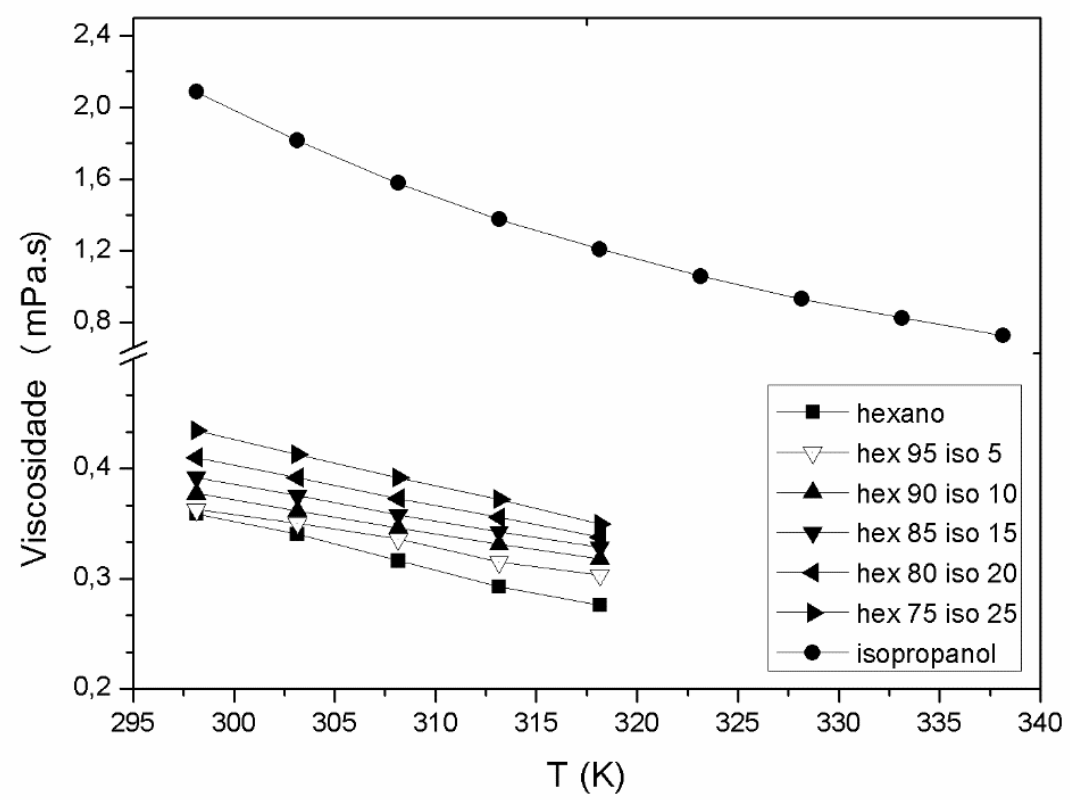

Fonte: Própria autoria. 
Figura 21 Viscosidades dinâmicas (mPa.s) do ciclohexano e etanol e suas respectivas misturas em função da temperatura.

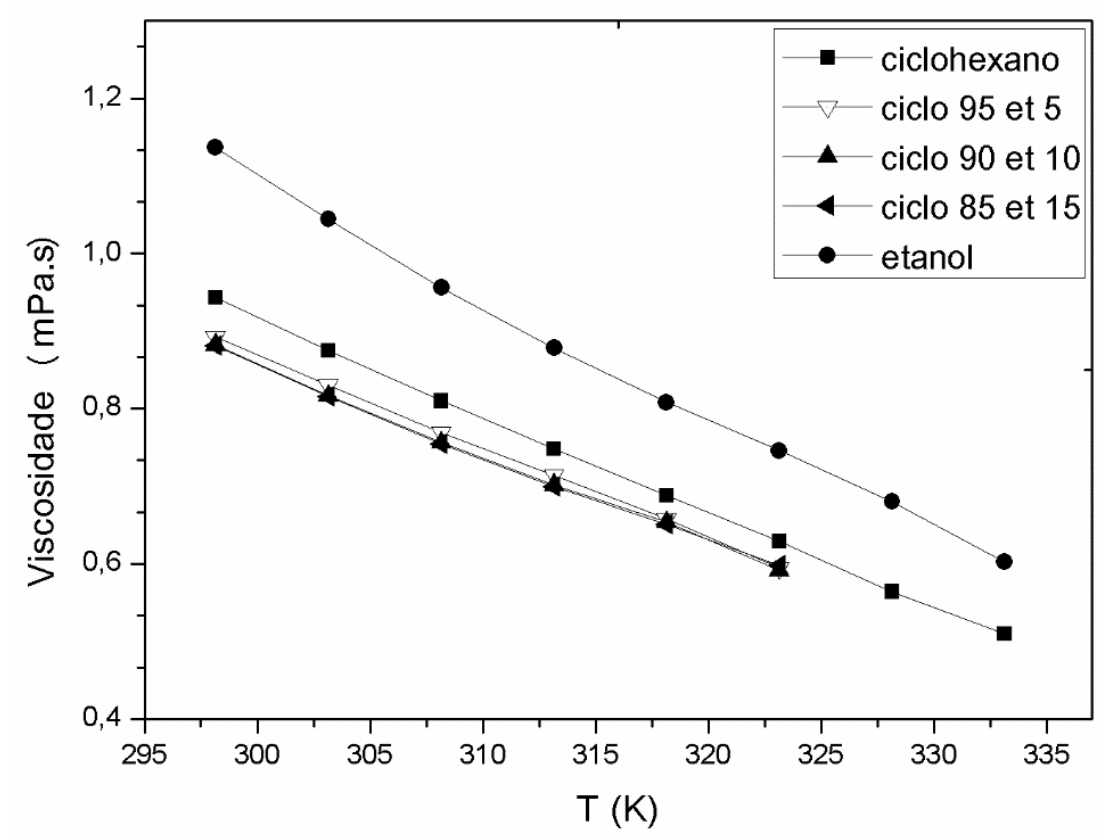

Fonte: Própria autoria.
Figura 22 Viscosidades dinâmicas (mPa.s) do ciclohexano e isopropanol e suas respectivas misturas em função da temperatura.

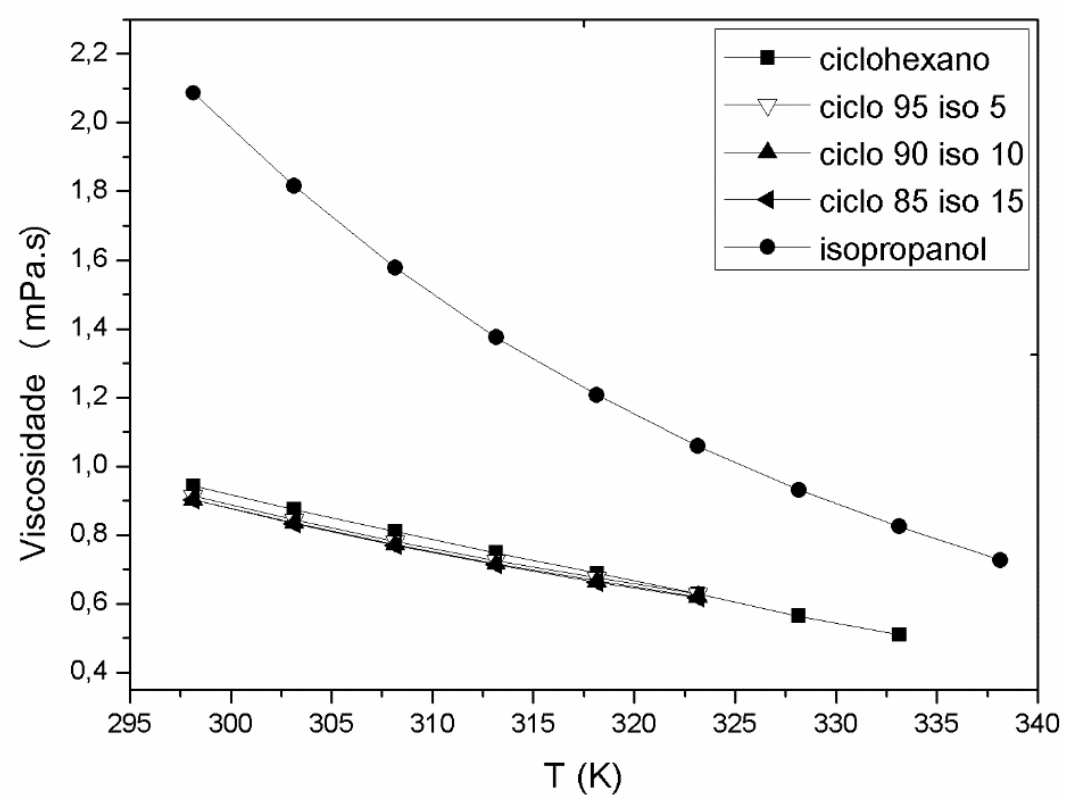

Fonte: Própria autoria. 
Figura 23 Viscosidades dinâmicas (mPa.s) do heptano e etanol e suas respectivas misturas em função da temperatura.

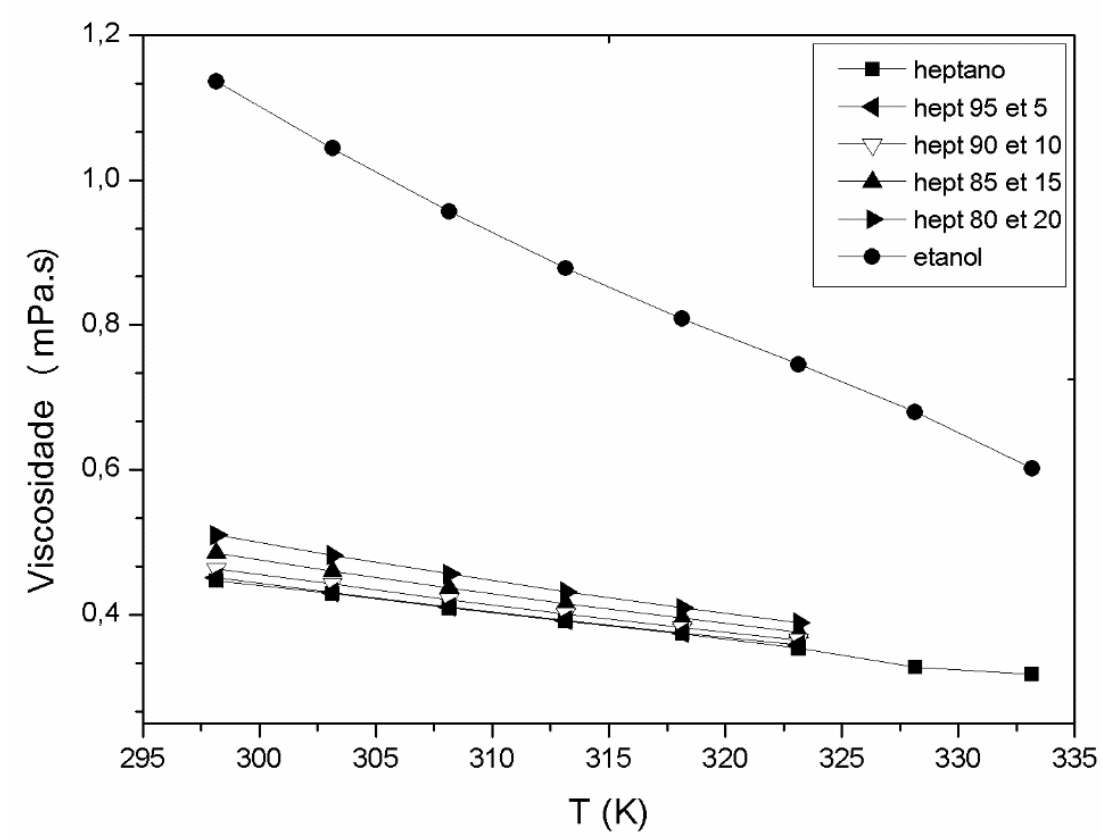

Fonte: Própria autoria
Figura 24 Viscosidades dinâmicas (mPa.s) do heptano e isopropanol e suas respectivas misturas em função da temperatura.

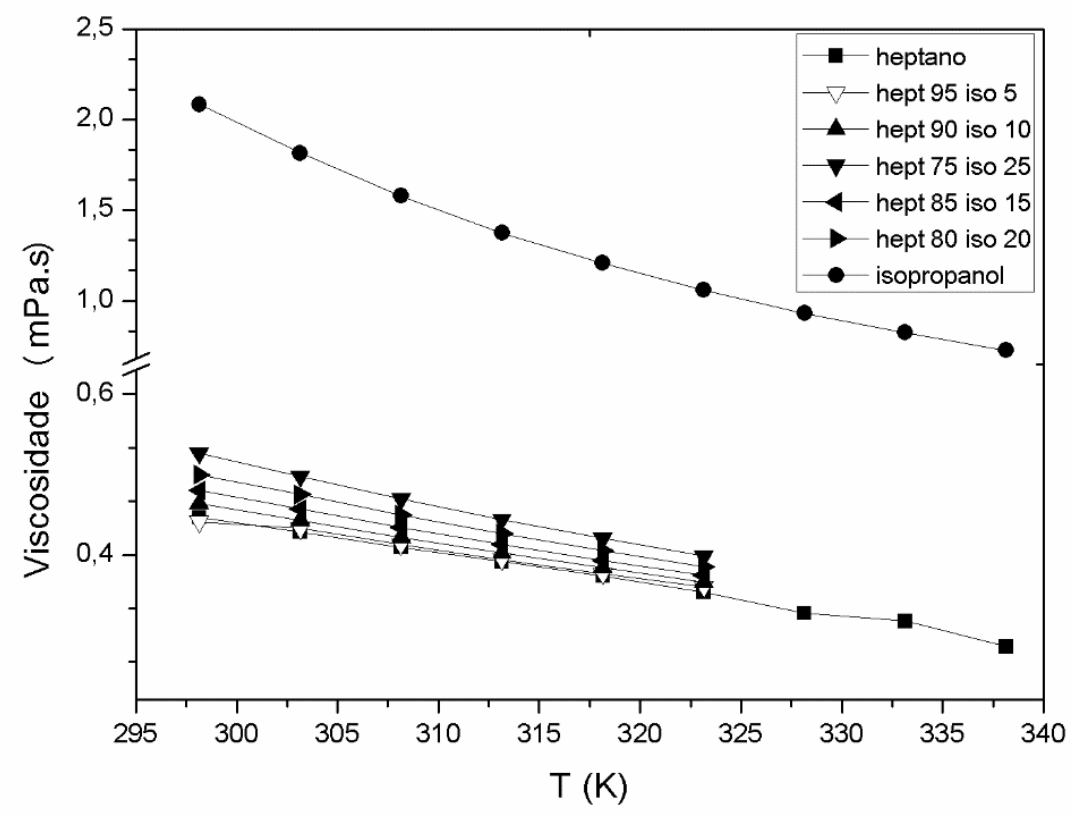

Fonte: Própria autoria. 
Entre todos os solventes puros e misturas de solventes analisados, na faixa de temperatura entre 298,15 a $313,15 \mathrm{~K}$, (de 25 a $40^{\circ} \mathrm{C}$ ) o isopropanol apresenta a maior viscosidade, seguido por etanol, ciclohexano, heptano e por último, com menor viscosidade, hexano. Seus respectivos valores podem ser visualizados no Apêndice D.

Adicionalmente, como esperado, o aumento da temperatura resultou na diminuição dos valores de viscosidade para todos os solventes e misturas de solventes estudadas.

Para possibilitar uma melhor investigação acerca das propriedades físicas dos solventes e misturas de solventes, os dados experimentais de massa específica e viscosidade dinâmica foram submetidos a regressão linear a fim de extrapolar os dados para a temperatura de trabalho, a $60^{\circ} \mathrm{C}$, para os sistemas nos quais não foi possível avaliar as propriedades físicas nesta temperatura devido às limitações operacionais do equipamento. Vale ressaltar que nesta dissertação, a extrapolação dos dados de viscosidade foi realizada em uma pequena faixa de temperatura, justificando-se o uso de regressão linear. Nos casos em que o valor desejado de viscosidade está distante da faixa de temperatura experimental, sugere-se o emprego de modelos mais robustos, tais como UNIFAC-VISCO, dentre outros. Nos Apêndices C e E é possível observar as figuras contendo as retas referentes aos ajustes lineares para a viscosidade e massa específica, respectivamente. Já nos Apêndices D e F estão as tabelas contendo os desvios entre os valores estimados de dados de viscosidade e massa específica e os valores experimentais, respectivamente.

Não foi possível determinar experimentalmente as propriedades físicas das misturas de solventes e do solvente hexano puro, a $60^{\circ} \mathrm{C}$. Logo, no Apêndice $D$, foram estimados os valores de viscosidade obtidos com os ajustes lineares dos dados e estes valores foram comparados com os dados obtidos experimentalmente, todos na temperatura onde foi possível a análise pelo equipamento (considerando que nem todos os solventes apresentaram o mesmo comportamento). O mesmo foi feito para os dados de massa específica, os quais estão apresentados no Apêndice F. Para os dados de viscosidade e massa específica, pode-se inferir que os ajustes lineares apresentaram bom desempenho considerando os elevados coeficientes de determinação, além disso, 
os desvios entre os valores estimados e os experimentais foram baixos (variando entre $0,01$ e $3,33 \%)$.

A $60^{\circ} \mathrm{C}$ os solventes que apresentaram as menores viscosidades e massas específicas foram hexano, seguido por suas misturas com os solventes alcoólicos, seguidos por heptano e suas misturas com etanol e isopropanol. O acréscimo de solvente alcoólico aos solventes hexano e heptano, resultou em acréscimo dos valores de viscosidade observados. No entanto, este comportamento não foi observado para as misturas compreendidas por ciclohexano e solventes alcoólicos, as quais tiveram seus valores de viscosidade reduzidos com o acréscimo de solventes alcoólicos, em uma mesma temperatura.

Os dados de viscosidade dinâmica obtidos para ciclohexano e suas misturas com etanol e isopropanol, a 25,30 e $35{ }^{\circ} \mathrm{C}$ estão em conformidade com os dados apresentados na literatura (GONZÁLEZ et al., 2007; PAPANASTASIOU; ZIOGAS, 1991; WEL; ROWLEY,1984).

Desta forma, pode-se inferir que o melhor desempenho do solvente hexano na extração de óleo, em relação aos demais solventes puros, está associado aos seus menores valores de $\mathrm{Di}$, massa específica e viscosidade, que afetam positivamente as etapas de transferência de massa, como sugerido por Toda et al. (2016).

O elevado rendimento de extração obtido pela utilização da mistura por heptano e isopropanol pode também estar relacionado ao aumento do número de carbonos dos solventes heptano e isopropanol, em relação ao hexano e etanol, respectivamente. Este acréscimo pode levar ao aumento de solubilidade dos compostos lipídicos e, consequentemente, um maior rendimento de extração (CAPELLINI et al., 2017; TODA et al., 2016).

O emprego de misturas de solventes hidrocarbonetos e alcoólicos, com composições definidas a partir do cálculo da distância soluto-solvente (Ra), objetivou inicialmente, a busca pelo sinergismo entre o uso de solventes com polaridades distintas e a maior recuperação de óleo de FPP rico em carotenoides. Embora este sinergismo tenha sido alcançado, em termos de maior rendimento de extração de óleo 
de FPP, com o uso da mistura compreendida por heptano e isopropanol, considerável rendimento de extração de óleo foi obtido com o uso de solventes polares, etanol e isopropanol, quando comparado aos solventes apolares, ciclohexano e heptano.

Outra variável de processo que apresenta impacto sobre o rendimento de extração é a retenção de solução aderida a fase rafinado.

A Tabela 13 apresenta os valores médios de índice de retenção (IR) de solução em função do tipo de solvente ou misturas de solventes empregados e a comparação estatística pelo teste de Duncan, ao nível de $95 \%$ de confiança.

Tabela 13 Índice de retenção (kg de solução aderida/kg de sólidos inertes) para experimentos de extração sólido-líquido em batelada utilizando diferentes solventes de extração.

\begin{tabular}{cccc}
\hline \multicolumn{2}{c}{ Fração mássica } & Solvente & $\begin{array}{c}\text { Índice de retenção (kg de solução } \\
\text { aderida/ kg de sólidos inertes) }\end{array}$ \\
\hline$(1)$ & $(2)$ & Etanol (1) & $1,71 \pm 0,04^{\mathrm{a}}$ \\
1 & 0 & Isopropanol (1) & $1,46 \pm 0,01^{\mathrm{b}}$ \\
1 & 0 & Hexano (1) & $0,76 \pm 0,02^{\mathrm{e}}$ \\
1 & 0 & Ciclohexano (1) & $1,4 \pm 0,1^{\mathrm{b}}$ \\
1 & 0 & Heptano (1) & $1,2 \pm 0,1^{\mathrm{cd}}$ \\
0,79 & 0,21 & Hexano (1): Etanol (2) & $1,13 \pm 0,01^{\mathrm{a}}$ \\
0,73 & 0,27 & Hexano (1): Isopropanol (2) & $1,12 \pm 0,05^{\mathrm{a}}$ \\
0,85 & 0,15 & Ciclohexano (1): Etanol (2) & $1,39 \pm 0,04^{\mathrm{b}}$ \\
0,82 & 0,18 & Ciclohexano (1): Isopropanol (2) & $1,33 \pm 0,03^{\mathrm{bc}}$ \\
0,81 & 0,19 & Heptano (1): Etanol (2) & $1,32 \pm 0,04^{\mathrm{bc}}$ \\
0,76 & 0,24 & Heptano (1): Isopropanol (2) & $1,10 \pm 0,04^{\mathrm{d}}$ \\
\hline
\end{tabular}

Letras minúsculas diferentes na mesma coluna indicam diferença estatística pelo teste Duncan $(p<0,05)$. Fonte: Própria autoria.

O valor do IR em processos de extração sólido-líquido é importante pois ele impacta decisivamente na capacidade em volume do extrator a ser utilizado, no número de estágios necessários para realizar a extração e na etapa de recuperação do solvente aderido ao rafinado, portanto, um menor IR é desejável considerando um menor gasto 
energético na etapa de dessolventização do sólido desengordurado restante (RODRIGUES; OLIVEIRA, 2010).

Com base na análise estatística dos valores médios de IR pode-se inferir que o etanol apresentou o maior valor de IR, seguido pelos solventes isopropanol, ciclohexano e a mistura de ciclohexano e etanol.

Diversos autores estudaram o índice de retenção em experimentos de extração sólido-líquido empregando solventes alcoólicos, sendo reportados aqui valores a $60{ }^{\circ} \mathrm{C}$.

Capellini (2013) realizou estudo sobre o processo de extração de óleo de pellets de farelo de arroz utilizando os solventes etanol e isopropanol e observou valores de solução aderida por massa de sólidos inertes de 0,47 $\pm 0,01$ e 0,40 $\pm 0,01(\mathrm{~kg} / \mathrm{kg})$ para estes solventes, respectivamente. Em estudo posterior com torta de gergelim, 0 emprego de etanol e isopropanol resultaram em índices de retenção iguais de 0,38 kg de solução aderida/ kg de sólidos inertes (CAPELLINI, 2017).

Scharlack (2015) obteve índices de retenção de 0,62 $\pm 0,02$ e 0,5 $\pm 0(\mathrm{~kg}$ de solução aderida/ $\mathrm{kg}$ de sólidos inertes) com o emprego de etanol e isopropanol na extração de óleo de torta de semente de girassol, respectivamente.

Estes resultados são, de modo geral, menores que os resultados obtidos neste trabalho.

Por outro lado, outros autores obtiveram valores maiores de índice de retenção. Toda (2016) no processo de extração de óleo de borra de café com solventes alcoólicos obteve valores de índice de retenção 1,79 \pm 0,02 ( $\mathrm{kg}$ de solução aderida/kg de sólidos inertes) com o uso de etanol e de 1,78 \pm 0,06 ( $\mathrm{kg}$ de solução aderida/kg de sólidos inertes) com o emprego de isopropanol.

Adicionalmente, Navarro (2016) obteve também maior valor de índice de retenção de 2,8 \pm 0,1 e 2,2 $\pm 0,1$ ( $\mathrm{kg}$ de solução aderida/kg de sólidos inertes) com o uso de etanol e isopropanol na extração de óleo torta de macadâmia, respectivamente.

Neste contexto, é possível inferir que as variações nos valores obtidos de índice de retenção podem ser decorrentes da forma física e do tratamento prévio à etapa de extração dado à matéria-prima (TODA, 2016; NAVARRO, 2016). 
Em adição, as misturas de solventes compreendidas por hexano e etanol, hexano e isopropanol e heptano e etanol resultaram valores intermediários de IR e estatisticamente iguais.

As misturas de hexano e etanol, hexano e isopropanol e heptano e isopropanol apresentaram os menores valores de IR dentre todas as misturas de solventes analisadas.

Na Figura 25 estão apresentados os dados de IR em função da constante dielétrica para os solventes e misturas de solventes.

Figura 25 Índice de retenção ( $\mathrm{kg}$ de solução aderida/kg de sólidos inertes) da fase rafinado de FPP em função da constante dielétrica para diferentes solventes e misturas de solventes.

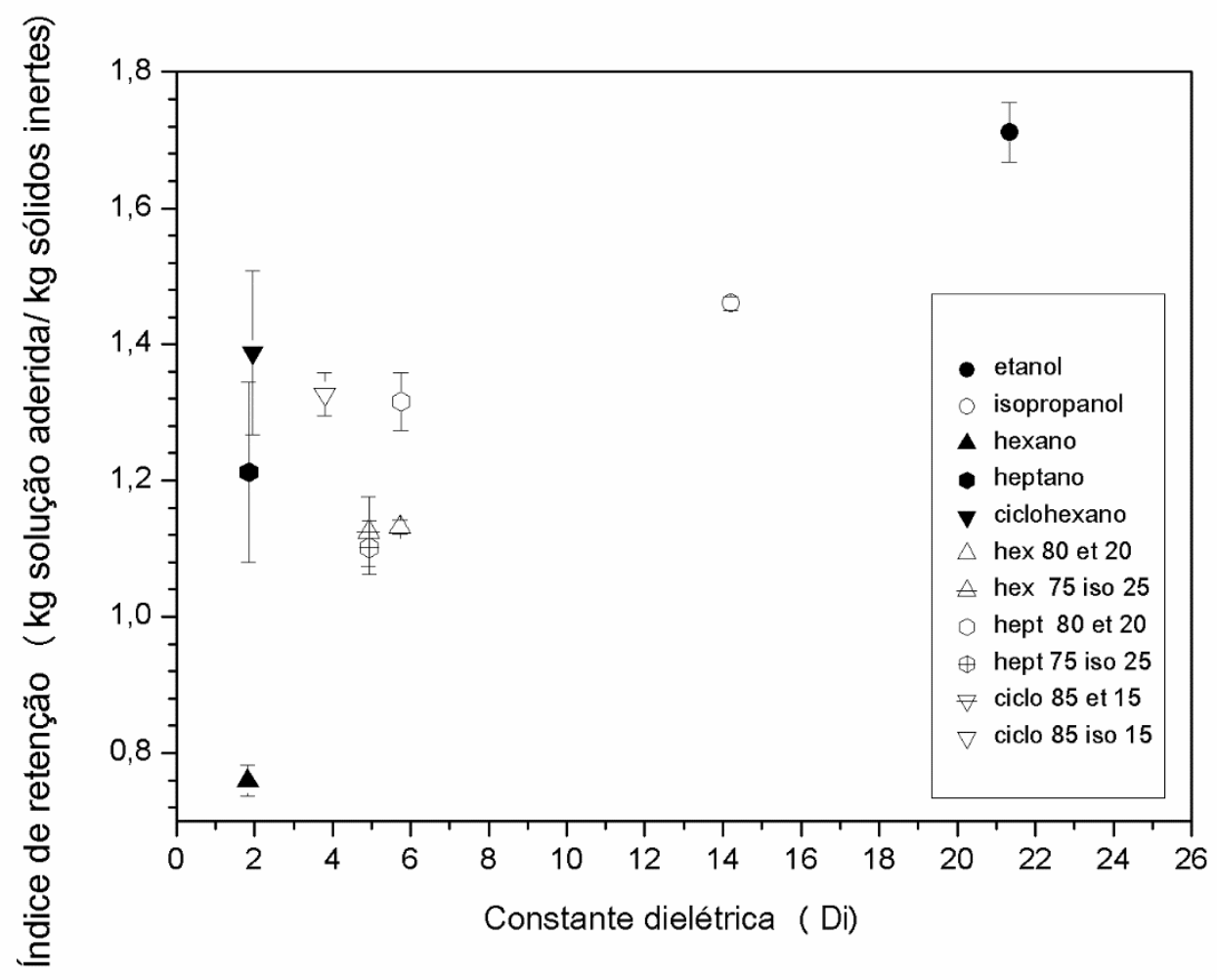

Fonte: Própria autoria. 
Rodrigues e Oliveira (2010) sugerem que solventes com elevada polaridade exercem uma força atrativa maior na parte hidrofílica do sólido resultando em maior quantidade de solução aderida no material desengordurado. De fato, a Figura 24 mostra que etanol apresentou o maior valor de $\mathrm{Di}$, e também o maior $\mathrm{IR}$, enquanto que hexano apresentou comportamento oposto. Apesar dos solventes hidrocarbonetos heptano e ciclohexano, e suas misturas com etanol e isopropanol, apresentarem baixos valores de Di (quando comparados aos solventes alcoólicos) seus valores de IR não seguiram este mesmo comportamento.

Rittner (1992) investigou o emprego de hexano na extração de óleo de soja resultando em menor valor de IR quando comparado ao etanol. Adicionalmente, em outro estudo, a extração de óleo de algodão com hexano resultou menor quantidade de solução aderida às fibras quando comparado ao solvente isopropanol (ZHANG; RHEE; KOSEOGLU, 2002). Tais resultados estão em conformidade com os dados obtidos no presente trabalho.

As propriedades físicas de massa específica e viscosidade dos solventes podem também influenciar a quantidade de solução aderida à massa de sólidos inertes. Como observado nas Figuras de 13 a 24 os solventes alcoólicos apresentam os maiores valores de massa específica e viscosidade, enquanto os solventes hidrocarbonetos são aqueles que apresentam os menores valores destas propriedades físicas. Desta forma, pode-se inferir que estes fatores também contribuíram para a obtenção de menores valores de índice de retenção, para hexano e valores superiores de retenção para etanol.

A adição de etanol e isopropanol ao hexano resultou no aumentou do IR, quando comparado ao valor obtido por hexano. Porém no caso do ciclohexano, a adição de solvente alcoólico não impactou o valor de IR provavelmente devido ao baixo conteúdo (em massa) de solvente alcoólico adicionado.

As extrações de óleo de FPP utilizando a razão sólido:solvente de 1:7, em massa, ou seja, alta quantidade de solvente, podem ter dificultado a observação de diferenças significativas de rendimento de extração de óleo de FPP com diferentes 
solventes e misturas de solventes empregados, uma vez que o equilíbrio pode não ter sido atingido devido à alta disponibilidade de solvente.

De fato, ensaios de extração com outras matérias-primas oleaginosas permitiram a utilização de uma razão sólido:solvente maior (1:3) (TERIGAR et al., 2011; OLIVEIRA et al., 2012; SAWADA et al., 2014; BESSA et al., 2017; CAPELLINI et al., 2017).

Bessa et al. (2017) realizaram com sucesso a extração de óleo de farelo de arroz utilizando uma unidade de extração sólido-líquido que possui como principal componente uma coluna de aço inox, com $50 \mathrm{~cm}$ de altura e $4,5 \mathrm{~cm}$ de diâmetro. Majumdar et al. (1995), por sua vez, estudaram a simulação de colunas empacotadas para a extração de óleos vegetais, enquanto Cerutti et al. (2012) realizaram experimentos em coluna empacotada para extração de óleo de soja. Desta forma, os trabalhos na literatura indicam que a utilização de colunas empacotadas pode ser interessante para extração de óleo de FPP.

Por essa razão, a fim de investigar o efeito da razão mássica sólido:solvente no rendimento de extração de óleo de FPP foram realizados experimentos de extração sólido-líquido em coluna empacotada de leito fixo, a qual, a partir de testes preliminares, permitiu a operação com uma razão sólido:solvente de 1:4, em massa.

5.4 Estudo do processo de extração de óleo de FPP em coluna empacotada de leito fixo

O estudo da cinética de extração sólido-líquido em coluna empacotada foi realizado utilizando etanol, uma vez que este solvente apresentou em experimentos preliminares o pior desempenho de extração de carotenoides no óleo de FPP, quando comparado aos demais solventes estudados.

Na Figura 26 estão apresentadas as curvas de cinética de extração de óleo de FPP e de carotenoides com ajuste qualitativo de modelo exponencial aos dados experimentais. 
Os valores médios de rendimento de extração de óleo de FPP e teor de carotenoides obtidos com etanol, em diferentes tempos são comparados através do Teste de Duncan, ao nível de $95 \%$ de confiança e estas análises estatísticas estão apresentados na Tabela 14.

De modo geral, a análise da Figura 26 permite inferir que os valores de rendimento relativo de extração de óleo de FPP com etanol mostraram-se estatisticamente iguais a partir de 15 minutos de extração (Tabela 14).

Figura 26 Cinética de extração de óleo de FPP e de carotenoides ( $\mathrm{mg} \beta$-caroteno/kg de óleo) utilizando etanol.

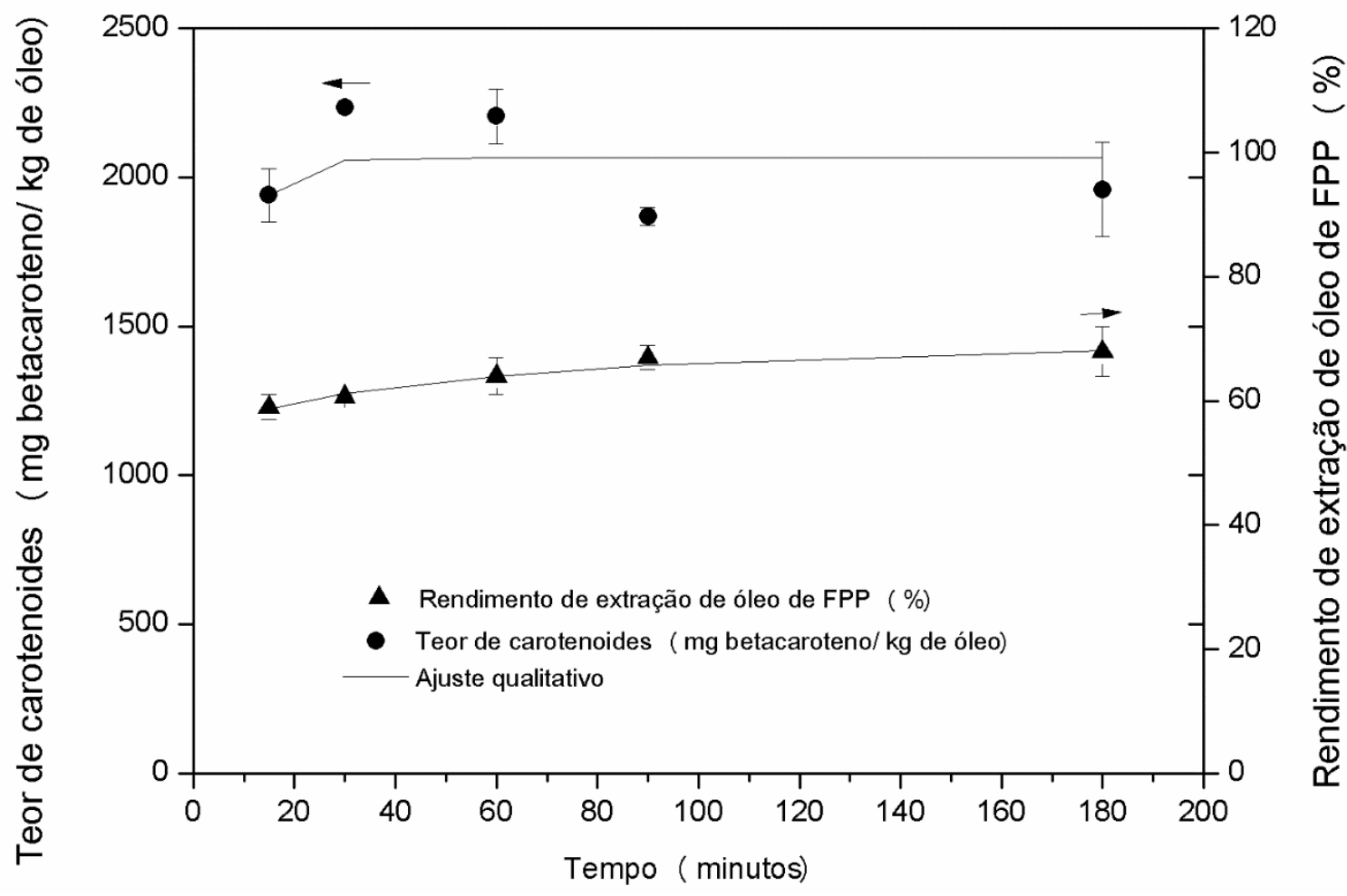

Fonte: Própria autoria.

No que diz respeito a extração de carotenoides, observou-se um leve decréscimo a partir de 90 minutos, como pode ser observado na Figura 26 e Tabela 14. A partir deste intervalo de tempo, o conteúdo de carotenoides extraído permaneceu constante. 
Este estudo preliminar de cinética de extração permitiu definir as condições dos experimentos com diferentes solventes, $55 \pm 3^{\circ} \mathrm{C}$ e 90 minutos de extração.

Tabela 14 Rendimento relativo (\%) de extração de óleo de FPP e teor carotenoides (mg $\beta$-caroteno $/ \mathrm{kg}$ de óleo) utilizando-se etanol, em função do tempo.

\begin{tabular}{ccc}
\hline $\begin{array}{c}\text { Tempo de extração } \\
\text { (minutos) }\end{array}$ & Rendimento (\%) & $\begin{array}{c}\text { Carotenoides (mg } \beta \text {-caroteno/ } \\
\text { kg de óleo) }\end{array}$ \\
\hline 15 & $59 \pm 2^{\mathrm{c}}$ & $1941 \pm 90^{\mathrm{b}}$ \\
30 & $60,7 \pm 0,3^{\mathrm{bc}}$ & $2266 \pm 6^{\mathrm{a}}$ \\
60 & $64 \pm 3^{\mathrm{abc}}$ & $2205 \pm 93^{\mathrm{a}}$ \\
90 & $67 \pm 2^{\mathrm{ab}}$ & $1824 \pm 41^{\mathrm{b}}$ \\
180 & $68 \pm 4^{\mathrm{a}}$ & $1960 \pm 159^{\mathrm{b}}$ \\
\hline
\end{tabular}

Letras minúsculas diferentes na mesma coluna indicam diferença estatística pelo teste Duncan $(p<0,05)$. Fonte: Própria autoria.

Para os experimentos em coluna empacotada de leito fixo os solventes empregados foram hexano, etanol, isopropanol e as misturas hexano e etanol e hexano e isopropanol, uma vez que o hexano apresentou o maior rendimento de extração de óleo de FPP nos experimentos em batelada (Figura 12). Embora o uso da mistura entre heptano e isopropanol tenha apresentado um elevado rendimento de extração, comparável ao hexano, devido à escassez de FPP não foi possível a utilização desta mistura nos experimentos em coluna empacotada de leito fixo, optando-se pelas misturas entre hexano e álcoois, uma vez que o hexano é o hidrocarboneto utilizado industrialmente pelas processadoras de óleos vegetais.

A composição da fase extrato em termos do teor de água pode ser observada na Tabela 15, onde está apresentada a comparação estatística entre os valores médios de teor de água na fase extrato para cada condição experimental pelo Teste de Duncan, ao nível de confiança de $95 \%$.

Assim como previamente discutido (Tabela 10), segundo a Tabela 15, observase que o solvente hexano apresenta a menor capacidade de extração de água para a fase extrato, seguido pelas misturas de hexano e etanol e hexano e isopropanol. Em 
relação aos solventes alcoólicos, estes extraíram o maior conteúdo de água, valores estatisticamente iguais, comportamento observado também em diversos outros estudos reportados na literatura (RODRIGUES; OLIVEIRA, 2010; CAPELLINI, 2013; SCHARLACK, 2015, TODA, 2016; NAVARRO, 2016).

Tabela 15 Teor de água na fase extrato (\%, em massa) para as extrações sólido-líquido em coluna empacotada com solventes alcoólicos, hexano e suas respectivas misturas.

\begin{tabular}{|c|c|c|c|}
\hline \multicolumn{2}{|c|}{ Fração mássica } & \multirow{2}{*}{ Solvente } & \multirow{2}{*}{$\begin{array}{c}\text { Teor médio de água na fase extrato } \\
\text { (g água/ } 100 \mathrm{~g} \text { de extrato) }\end{array}$} \\
\hline (1) & (2) & & \\
\hline 1 & 0 & Etanol (1) & $1,55 \pm 0,01^{a}$ \\
\hline 1 & 0 & Isopropanol (1) & $1,57 \pm 0,06^{a}$ \\
\hline 1 & 0 & Hexano (1) & $0,01 \pm 0,01^{a}$ \\
\hline 0,79 & 0,21 & Hexano (1): Etanol (2) & $0,59 \pm 0,02^{c}$ \\
\hline 0,73 & 0,27 & Hexano (1): Isopropanol (2) & $0,9 \pm 0,1^{\mathrm{b}}$ \\
\hline
\end{tabular}

A transferência de água para a fase extrato em função da constante dielétrica está apresentada na Figura 27. 
Figura 27 Transferência de água (\%) para a fase extrato em função da constante dielétrica.

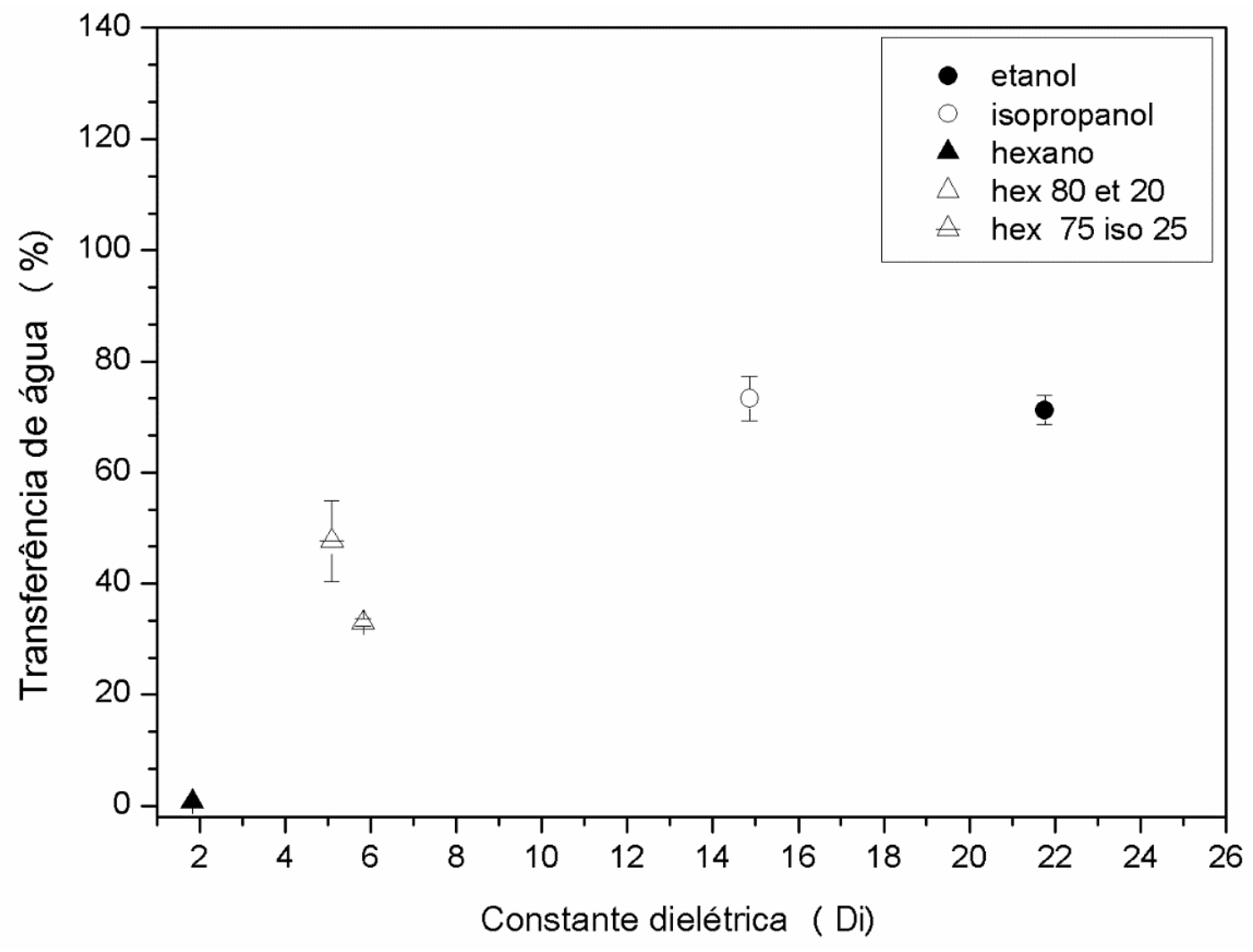

Fonte: Própria autoria.

Conforme apresentado anteriormente (vide Tabela 11), o solvente hexano e as misturas compreendidas por hexano e os álcoois de cadeia curta apresentam os menores valores de $\mathrm{Di}$, quando comparados aos solventes alcoólicos puros. Por essa razão, pode-se inferir que a menor polaridade destes solventes, dificulta a transferência da água para a fase extrato.

Os resultados de rendimento relativo de extração de óleo de FPP utilizando solventes puros e misturas de solventes relativos aos experimentos em coluna empacotada podem ser observados na Figura 28. 
Figura 28 Rendimento relativo (\%) de extração de óleo de FPP utilizando etanol, isopropanol, hexano e as misturas para extração em coluna empacotada.
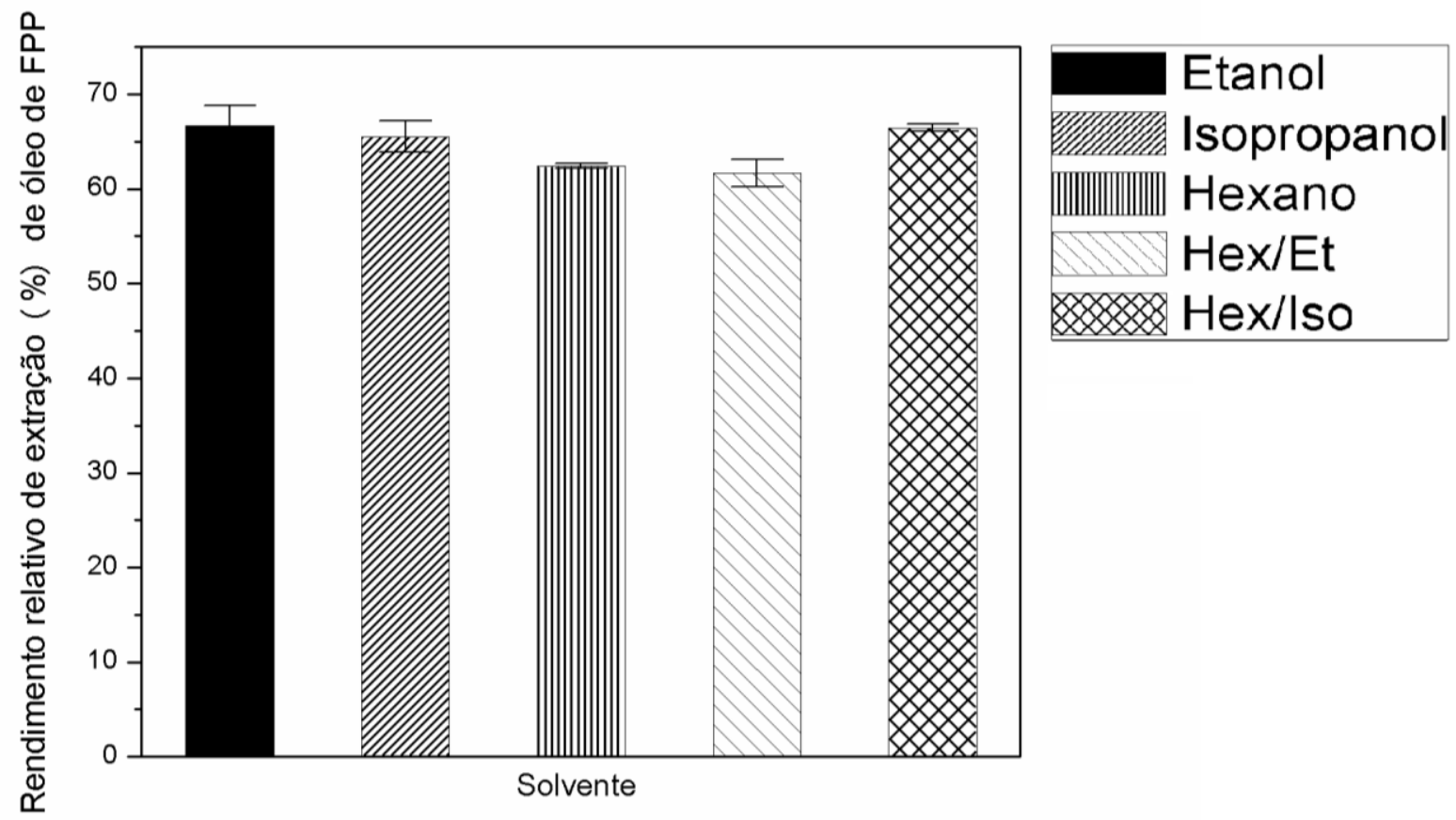

Fonte: Própria autoria.

A análise estatística dos valores médios de rendimento relativo de extração de óleo de FPP está apresentada na Tabela 16, ao nível de confiança de $95 \%$ pelo Teste de Duncan.

De modo geral, os resultados apresentados na Tabela 16 permitem inferir que a alteração do processo de extração em batelada para coluna, resultou na diminuição dos valores de rendimento de extração utilizando solventes puros ou misturas de solventes. Esta redução pode estar relacionada a vários fatores, tais como a diminuição do tempo de extração de 5 horas para 90 minutos, diminuição da quantidade de solvente em relação a FPP e, também, devido à diminuição da temperatura de extração para $55 \pm 3$ ${ }^{\circ} \mathrm{C}$. Esta redução nos valores de rendimento foi maior para o hexano que possibilitou obter nos experimentos em batelada rendimentos em torno de $80 \pm 4 \%$. 
Tabela 16 Rendimento relativo (\%) de extração de óleo de fibra prensada de palma em coluna empacotada, utilizando solventes alcoólicos, hexano e suas misturas.

\begin{tabular}{|c|c|c|c|c|c|}
\hline \multicolumn{2}{|c|}{$\begin{array}{l}\text { Fração } \\
\text { mássica }\end{array}$} & \multirow[t]{2}{*}{ Solvente } & \multirow{2}{*}{$\begin{array}{l}\text { Rendimento (\%) } \\
\text { (média } \pm \text { desvio) }\end{array}$} & \multirow{2}{*}{$\begin{array}{l}\text { Teor de sólidos } \\
\text { solúveis }(\%)^{1} \\
\text { (média } \pm \text { desvio) }\end{array}$} & \multirow{2}{*}{$\begin{array}{c}\text { Teor de óleo } \\
\text { residual }(\%)^{2} \\
\text { (média } \pm \text { desvio) }\end{array}$} \\
\hline$(1)$ & $(2)$ & & & & \\
\hline 1 & 0 & Etanol (1) & $67 \pm 2^{a}$ & $1,65 \pm 0,05^{\mathrm{ab}}$ & $1,7 \pm 0,1^{\mathrm{ab}}$ \\
\hline 1 & 0 & Isopropanol (1) & $66 \pm 2^{\mathrm{ab}}$ & $1,48 \pm 0,06^{\mathrm{c}}$ & $1,71 \pm 0,04^{\mathrm{ab}}$ \\
\hline 1 & 0 & Hexano (1) & $62,4 \pm 0,3^{\mathrm{DC}}$ & $1,29 \pm 0,06^{d}$ & $1,7 \pm 0,1^{\mathrm{ab}}$ \\
\hline 0,79 & 0,21 & Hexano (1): Etanol (2) & $62 \pm 1^{c}$ & $1,8 \pm 0,1^{a}$ & $1,85 \pm 0,08^{a}$ \\
\hline 0,73 & 0,27 & Hexano (1): Isopropanol (2) & $66,4 \pm 0,4^{a}$ & $1,54 \pm 0,05^{\mathrm{bc}}$ & $1,61 \pm 0,02^{b}$ \\
\hline
\end{tabular}

'Determinado na fase extrato. ${ }^{2}$ Determinado na fase rafinado. Letras minúsculas diferentes na mesma coluna indicam diferença estatística pelo teste Duncan $(p<0,05)$. Fonte: Própria autoria.

Os solventes alcoólicos apresentaram um bom desempenho de extração de óleo nos experimentos em coluna. Ademais, o acréscimo de isopropanol ao hexano promoveu maior extração de óleo de FPP quando comparado ao valor obtido pelo hexano puro.

Os valores médios de índice de retenção relativos aos experimentos em coluna empacotada estão apresentados na Tabela 17 e são comparados através da análise estatística segundo Teste de Duncan, ao nível de $95 \%$ de confiança.

Tabela 17 Índice de retenção ( $\mathrm{kg}$ de solução aderida/kg de sólidos inertes) para experimentos de extração sólido-líquido em coluna empacotada utilizando solventes alcoólicos, hexano e suas respectivas misturas.

\begin{tabular}{cccc}
\hline \multicolumn{2}{c}{ Fração mássica } & Solvente & $\begin{array}{c}\text { Índice de retenção (kg de solução } \\
\text { aderida/kg de sólidos inertes) }\end{array}$ \\
\hline$(1)$ & $(2)$ & Etanol (1) & $1,2 \pm 0,1^{\mathrm{a}}{ }^{\mathrm{a}}$ \\
\hline 1 & 0 & Isopropanol (1) & $1,10 \pm 0,06^{\mathrm{a}}$ \\
1 & 0 & Hexano (1) & $0,7 \pm 0,1^{\mathrm{b}}$ \\
0,79 & 0 & Hexano (1): Etanol (2) & $0,39 \pm 0,04^{\mathrm{c}}$ \\
0,73 & 0,21 & Hexano (1): Isopropanol (2) & $0,68 \pm 0,03^{\mathrm{b}}$ \\
\hline
\end{tabular}

Letras minúsculas diferentes na mesma coluna indicam diferença estatística pelo teste Duncan $(p<0,05)$. Fonte: Própria autoria. 
Adicionalmente, os valores de índice de retenção ( $\mathrm{kg}$ de solução aderida/ kg de sólidos inertes) em função da constante dielétrica estão apresentados na Figura 29.

Figura 29 Índice de retenção ( $\mathrm{kg}$ de solução aderida/kg de sólidos inertes) da fase rafinado de FPP em função da constante dielétrica para diferentes solventes e misturas de solventes.

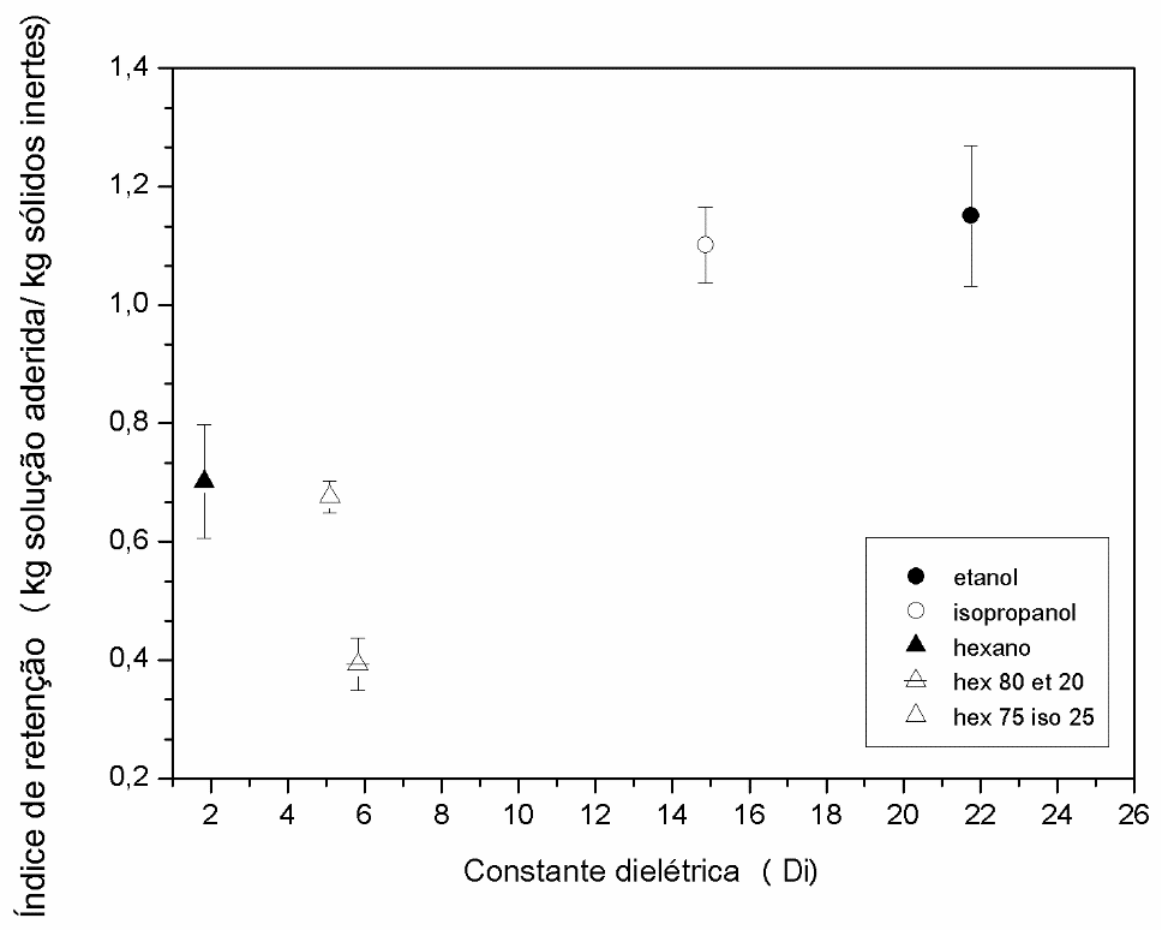

Fonte: Própria autoria.

Pode-se inferir que o menor valor de índice de retenção foi obtido com a mistura hexano e etanol, seguido por hexano e a mistura de hexano e isopropanol.

Segundo a Figura 29, pode-se perceber que os solventes alcoólicos apresentam as maiores polaridades que resultaram também nos maiores valores de IR. Por outro lado, a adição de solvente alcoólico ao hexano, apesar de aumentar os valores de Di e, consequentemente, a polaridade da mistura, não foi suficiente para resultar no aumento de IR para essas misturas. 
O maior valor de índice de retenção obtido pela mistura de hexano e isopropanol, quando comparado à mistura compreendida por hexano e etanol, pode estar relacionada ao aumento de viscosidade da mistura devido a adição de isopropanol, já que este último apresenta a maior viscosidade dentre todos os solventes estudados (vide Figura 20).

Comparando-se os valores de IR apresentados na Tabela 17, para os experimentos em coluna, com os valores referentes aos experimentos de extração em batelada (Tabela 13), pode-se inferir que a configuração em coluna possibilita uma drenagem mais fácil do leito de sólidos, resultando em valores de IR estatisticamente menores.

5.5 Caracterização do óleo de fibra prensada de palma obtido com diferentes solventes

Os teores de carotenoides e acidez livre no óleo de FPP obtido com solventes puros e misturas de solventes, através dos experimentos de extração em batelada e em coluna, além do tratamento estatístico destes valores médios pelo Teste de Duncan, ao nível de $95 \%$ de confiança, estão apresentados na Tabela 18.

Neste trabalho, a metodologia de extração de óleo de FPP, proposta por Neoh et al. (2011) foi a escolhida para extração de óleo de FPP rico em carotenoides para ser comparada às extrações com os solventes propostos. Estes autores reportam um maior rendimento de extração de óleo, de aproximadamente 4,35 \% (g óleo/ $100 \mathrm{~g}$ de FPP) com o emprego de hexano na proporção sólido:solvente, de 1:5 (em massa), por 8 horas e a temperatura ambiente, em comparação a 3,78 \% (g óleo/100 g de FPP) obtidos via extração por Sohxlet na mesma razão sólido:solvente. Os autores reportam que tal acréscimo pode estar relacionado ao aumento da superfície de contato com o contato direto entre hexano e a FPP. Ademais, o uso de hexano à temperatura ambiente, nesta dissertação, visou promover a menor degradação possível dos carotenoides. 
Tabela 18 Teor de carotenoides ( $\mathrm{mg} \beta$-caroteno/ $\mathrm{kg}$ de óleo) e acidez livre (\%, em massa) no óleo de fibra prensada de palma obtido das extrações sólido-líquido em batelada e em coluna empacotada utilizando diferentes solventes.

\begin{tabular}{|c|c|c|c|c|c|c|}
\hline \multicolumn{2}{|c|}{$\begin{array}{l}\text { Fração } \\
\text { mássica }\end{array}$} & \multirow[t]{2}{*}{ Solvente } & \multicolumn{2}{|c|}{$\begin{array}{c}\text { Teor de carotenoides } \\
\text { (mg } \beta \text {-caroteno/ } \mathrm{kg} \text { de óleo) }\end{array}$} & \multicolumn{2}{|c|}{ Teor de AGL (\%) } \\
\hline (1) & $(2)$ & & batelada & coluna & batelada & coluna \\
\hline 1 & 0 & Etanol (1) & $1831 \pm 11^{\mathrm{de} A}$ & $1824 \pm 41^{\mathrm{CA}}$ & $19,2 \pm 0,3^{a A}$ & $19,7 \pm 0,1^{a A}$ \\
\hline 1 & 0 & Isopropanol (1) & $2012 \pm 116^{\text {cdeA }}$ & $2023 \pm 12^{\mathrm{DA}}$ & $19 \pm 1^{\mathrm{aA}}$ & $16,8 \pm 0,2^{\mathrm{bcA}}$ \\
\hline 1 & 0 & Hexano (1) & $2539 \pm 78^{\mathrm{aA}}$ & $1949 \pm 30^{\mathrm{bcb}}$ & $16,5 \pm 0,2^{\mathrm{bcA}}$ & $16 \pm 2^{\mathrm{bcA}}$ \\
\hline 1 & 0 & Ciclohexano (1) & $2410 \pm 181^{\mathrm{ab}}$ & & $12,7 \pm 0,2^{e}$ & \\
\hline 1 & 0 & Heptano (1) & $2196 \pm 217^{\mathrm{abcd}}$ & & $15,8 \pm 0,2^{c}$ & \\
\hline 0,79 & 0,21 & $\begin{array}{l}\text { Hexano (1): } \\
\text { Etanol (2) }\end{array}$ & $2089 \pm 174^{\text {bcdeA }}$ & $2012 \pm 27^{\mathrm{bA}}$ & $16,0 \pm 0,2^{\mathrm{bcB}}$ & $17,3 \pm 0,1^{\mathrm{bA}}$ \\
\hline 0,73 & 0,27 & $\begin{array}{l}\text { Hexano (1): } \\
\text { Isopropanol (2) }\end{array}$ & $1790 \pm 230^{\mathrm{eA}}$ & $1923 \pm 32^{\mathrm{bcA}}$ & $14,5 \pm 0,1^{\mathrm{dB}}$ & $15,2 \pm 0,2^{\mathrm{cA}}$ \\
\hline 0,85 & 0,15 & $\begin{array}{l}\text { Ciclohexano (1): } \\
\text { Etanol (2) }\end{array}$ & $1875 \pm 121^{\text {de }}$ & & $16,32 \pm 0,03^{b c}$ & \\
\hline 0,82 & 0,18 & $\begin{array}{l}\text { Ciclohexano (1): } \\
\text { Isopropanol (2) }\end{array}$ & $1800 \pm 67^{e}$ & & $16,9 \pm 0,1^{b}$ & \\
\hline 0,81 & 0,19 & $\begin{array}{l}\text { Heptano (1): } \\
\text { Etanol (2) }\end{array}$ & $2066 \pm 238^{\text {bcde }}$ & & $16,0 \pm 0,5^{\mathrm{bc}}$ & \\
\hline 0,76 & 0,24 & $\begin{array}{l}\text { Heptano (1): } \\
\text { Isopropanol (2) }\end{array}$ & $1858 \pm 19^{\mathrm{de}}$ & & $16,5 \pm 0,2^{\mathrm{bc}}$ & \\
\hline \multicolumn{3}{|c|}{ Óleo de FPP extraído a frio* } & $2360 \pm 152^{\mathrm{abc}}$ & $2360 \pm 152^{a}$ & $15,7 \pm 0,6^{c}$ & $15,7 \pm 0,6^{\mathrm{bC}}$ \\
\hline
\end{tabular}

Nesta dissertação, o conteúdo de carotenoides, expresso como $\beta$-caroteno, assemelha-se mais ao conteúdo reportado por Lau et al. (2006). Estes autores compararam o efeito da umidade inicial presente na FPP, no conteúdo de carotenoides recuperado a partir da extração, do tipo Sohxlet, com hexano, na temperatura entre 76 a $80{ }^{\circ} \mathrm{C}$. De fato, a extração de óleo da fibra úmida, com umidade entre 35 a $40 \%$ resultou em menor conteúdo de carotenoides de $2933 \pm 11 \mathrm{mg}$ de $\beta$-caroteno/ $\mathrm{kg}$ de 
óleo quando comparado ao conteúdo extraído deste componente da fibra seca de 4007 $\pm 15 \mathrm{mg}$ de $\beta$-caroteno/ $\mathrm{kg}$ de óleo.

Para os experimentos em batelada, o emprego do solvente puro hexano resultou no maior conteúdo de carotenoides seguido pelo uso de ciclohexano. Quando comparados à extração a frio com hexano, proposta por Neoh et al. (2011), percebe-se que os resultados de transferência deste componente para o óleo vegetal são estatisticamente iguais.

Além disso, ciclohexano apresenta o menor valor de Ra (vide Tabela 9), o que denota, portanto, sua melhor capacidade em solubilizar $\beta$-caroteno.

Ademais, as propriedades físicas do hexano, tal como sua menor polaridade, viscosidade e massa específica, podem de fato contribuir para a maior transferência de carotenoides para o óleo de FPP.

Por outro lado, a utilização de etanol e isopropanol influencia negativamente a extração de carotenoides, o que já era esperado visto que a Ra entre carotenoides e etanol e isopropanol apresentaram os maiores valores (vide Tabela 9). Navarro et al. (2016) obtiveram um conteúdo superior de carotenoides em óleo de gérmen de milho extraído com o uso de isopropanol (373 $\pm 9 \mathrm{mg} \beta$-caroteno/ $\mathrm{g}$ de óleo) quando comparado ao valor obtido por etanol (287 $\pm 24 \mathrm{mg} \beta$-caroteno/ $\mathrm{g}$ de óleo), na razão sólido:líquido, de $1: 3$ (em massa), a $70^{\circ} \mathrm{C}$, porém tal comportamento não foi observado para o solvente isopropanol neste estudo.

De um modo geral, a adição de isopropanol aos solventes hidrocarbonetos hexano e ciclohexano prejudicou mais a transferência de carotenoides para óleo de FPP, do que a adição de etanol para estes mesmos solventes, apresentando os menores teores de carotenoides.

No caso dos experimentos de extração conduzidos em coluna, o emprego de isopropanol e da mistura entre hexano e etanol resultou em aumento de extração de carotenoides, enquanto que etanol recuperou o menor conteúdo deste minoritário, quando comparado aos demais solventes e misturas de solventes, como pode ser observado na Tabela 18. 
A análise dos parâmetros de Hansen apresentados na Tabela 4 mostra que as interações dipolo moleculares $\left(8,8 \mathrm{MPa}^{1 / 2}\right)$ e de ponte de hidrogênio $\left(19,4 \mathrm{MPa}^{1 / 2}\right)$ presentes na molécula de etanol são maiores que essas interações presentes no $\beta$ caroteno, reportadas por Ozel e Gogus (2014), com valores de 0,8 e 1,7 $\mathrm{MPa}^{1 / 2}$, para os parâmetros $\delta_{\mathrm{P}}$ e $\delta_{\mathrm{H}}$, respectivamente, $\mathrm{o}$ que pode justificar $\mathrm{o}$ menor teor de carotenoides extraído por este solvente.

De maneira geral, os dois métodos de extração, em batelada e coluna, apresentaram o mesmo desempenho na obtenção de carotenoides, com exceção do hexano que apresentou redução do conteúdo de carotenoides em experimentos em coluna. Este fato pode estar relacionado à diminuição da temperatura de extração em coluna, a $55^{\circ} \mathrm{C}$.

A utilização de misturas de solventes com composições determinadas através do cálculo da Ra não resultou em expressiva transferência de carotenoides para o óleo de FPP, para todas as misturas de solventes empregadas, em batelada e em coluna. $O$ acréscimo de teores de solventes alcoólicos, relativamente baixos, foi efetivo na diminuição da solubilidade entre os carotenoides e as misturas compreendidas por solventes hidrocarbonetos e álcoois. Porém, estes valores, variando entre $1790 \pm 230 \mathrm{a}$ $2089 \pm 174 \mathrm{mg} \beta$-caroteno/ $\mathrm{kg}$ obtidos pelos solventes alcoólicos, etanol e isopropanol, e suas respectivas misturas com os solventes hexano, ciclohexano e heptano, são ainda, relativamente altos quando comparados a outros óleos vegetais conforme mostrado na Tabela 1.

As composições em carotenoides, em termos de $\beta$ - e $\alpha$ - caroteno e licopeno, dos óleos extraídos com os diferentes solventes nos experimentos em coluna e analisados em UPLC/MS estão apresentadas na Tabela 19. Os resultados são comparados através da análise estatística segundo Teste de Duncan, ao nível de $95 \%$ de confiança.

O solvente hexano extraiu o maior conteúdo de $\beta$-caroteno, seguido pelas misturas de hexano e etanol e hexano e isopropanol que não diferiram entre si, enquanto que isopropanol apresentou o pior desempenho de extração deste pigmento. Em relação à extração de $\alpha$-caroteno, a mistura de hexano e etanol apresentou a maior 
extração deste componente, seguida pelos solventes puros por hexano e isopropanol que apresentaram o mesmo desempenho. A maior extração de licopeno deu-se com o emprego dos solventes hexano e etanol puros e suas misturas.

Tabela 19 Conteúdo de carotenoides nos óleos de FPP extraídos com diferentes solventes em coluna empacotada e analisados em UPLC/MS.

\begin{tabular}{|c|c|c|c|c|c|c|}
\hline \multicolumn{2}{|c|}{$\begin{array}{l}\text { Fração } \\
\text { mássica }\end{array}$} & \multirow{2}{*}{ Solvente } & \multirow{2}{*}{$\begin{array}{c}\text { Teor de } \beta- \\
\text { caroteno } \\
\text { (mg } \beta- \\
\text { caroteno/ kg } \\
\text { de óleo) }\end{array}$} & \multirow{2}{*}{$\begin{array}{l}\text { Teor de } \alpha- \\
\text { caroteno } \\
\text { (mg } \alpha- \\
\text { caroteno/ kg } \\
\text { de óleo) }\end{array}$} & \multirow{2}{*}{$\begin{array}{c}\text { Teor de } \\
\text { licopeno } \\
\text { (mg licopeno/ } \\
\text { kg de óleo) }\end{array}$} & \multirow{2}{*}{$\begin{array}{c}\text { Teor total } \\
\text { (mg } \beta \text {-caroteno } \\
+\alpha \text {-caroteno + } \\
\text { licopeno/ kg de } \\
\text { óleo) }\end{array}$} \\
\hline (1) & (2) & & & & & \\
\hline 1 & 0 & Etanol (1) & $105 \pm 10^{c}$ & $51,3 \pm 0,4^{c}$ & $114 \pm 1^{a}$ & $271 \pm 11^{\mathrm{b}}$ \\
\hline 1 & 0 & Isopropanol (1) & $79 \pm 3^{d}$ & $76 \pm 5^{\mathrm{b}}$ & $97 \pm 6^{c}$ & $252 \pm 14^{c}$ \\
\hline 1 & 0 & Hexano (1) & $131 \pm 2^{a}$ & $89 \pm 5^{b}$ & $110 \pm 4^{\mathrm{ab}}$ & $331 \pm 10^{a}$ \\
\hline 0,79 & 0,21 & Hexano (1): Etanol (2) & $113 \pm 8^{\mathrm{bc}}$ & $110 \pm 10^{a}$ & $101,1 \pm 0,4^{\mathrm{bc}}$ & $324 \pm 18^{\mathrm{a}}$ \\
\hline \multirow[t]{2}{*}{0,73} & 0,27 & $\begin{array}{c}\text { Hexano (1): } \\
\text { Isopropanol (2) }\end{array}$ & $129 \pm 8^{a b}$ & $59 \pm 4^{c}$ & $83 \pm 5^{d}$ & $272 \pm 17^{b}$ \\
\hline & & & $\begin{array}{c}\beta \text {-caroteno } \\
(\%)\end{array}$ & $\alpha$-caroteno (\%) & ) licopeno (\%) & Total (\%) \\
\hline 1 & 0 & Etanol (1) & 38,82 & 18,94 & 42,24 & 100,00 \\
\hline 1 & 0 & Isopropanol (1) & 31,32 & 30,02 & 38,66 & 100,00 \\
\hline 1 & 0 & Hexano (1) & 39,74 & 26,89 & 33,36 & 100,00 \\
\hline 0,79 & 0,21 & Hexano (1): Etanol (2) & 34,80 & 33,98 & 31,23 & 100,00 \\
\hline \multirow[t]{2}{*}{0,73} & 0,27 & $\begin{array}{c}\text { Hexano (1): } \\
\text { Isopropanol (2) }\end{array}$ & 47,46 & 21,79 & 30,75 & 100,00 \\
\hline & & Literatura $^{a}$ & 47,96 & 30,14 & 21,90 & 100,00 \\
\hline
\end{tabular}

A Good Source of Natural Carotenoids, Vitamin E, and Sterols. Journal of the American Oil Chemists' Society, v. 73 , n. 5, p. 599-602, 1996. Letras minúsculas diferentes na mesma coluna indicam diferença estatística pelo teste Duncan $(p<0,05)$. Fonte: Própria autoria.

Lin e Chen (2003) reportam uma maior eficiência na extração de carotenoides de suco de tomate (razão sólido:solvente, de 1:5, massa por volume) a partir da utilização da mistura compreendida por etanol e hexano, na razão 4:3 (em volume), quando comparada às misturas de acetona e hexano (razão 3:5, em volume), etanol, 
acetona e hexano (razão 2:1:3, em volume), acetato de etila:hexano (razão 1:1, em volume) e acetato de etila puro.

Adicionalmente, dentre 6 diferentes misturas de solventes avaliadas, incluindo a mistura de hexano:isopropanol (razão 3:2, em volume), Taungbodhitham et al. (1998) obtiveram maior recuperação de licopeno, $\alpha$ - caroteno e $\beta$-caroteno com o emprego de etanol e hexano (razão 4:3, em volume).

De fato, estes resultados assemelham-se aos dados obtidos em coluna, apresentados na Tabela 18, e aos valores analisados em UPLC, Tabela 19, apesar do elevado conteúdo de solvente alcoólico empregado por esses autores.

Choo et al. (1996) investigaram a composição de óleo de FPP extraído pelo método tradicional Soxhlet, com hexano, em termos de diferentes carotenoides, e dentre os 12 diferentes tipos encontrados, $\beta$ - e $\alpha$ - caroteno e licopeno estiveram presentes em maiores quantidades, apresentando valores de 30, 95, 19,45 e 14,13\%, respectivamente, de um total de $4520-5600 \mathrm{mg} / \mathrm{kg}$. Se fizermos uma estimativa da composição em carotenoides do óleo de FPP reportados por estes autores, considerando apenas a soma dos valores obtidos por estes três carotenoides majoritários, é possível comparar estes valores com os dados obtidos neste trabalho e estes dados estão apresentados na Tabela 19.

Em linhas gerais, a proporção entre os tipos de carotenoides extraídos pelos solventes puros e misturas de solventes não diferiu fortemente entre si e também dos valores obtidos por Choo et al. (1996). No entanto, nota-se maior conteúdo de licopeno extraído por etanol.

De fato, etanol apresenta o maior valor de $\mathrm{Di}$ e consequentemente, maior polaridade dentre todos os solventes puros e misturas de solventes empregados.

Como se observa na Figura 30 embora os três carotenoides apresentem a mesma massa molar, eles possuem estruturas moleculares distintas. A estrutura acíclica do licopeno e seu maior número de duplas ligações podem ter atuado de forma a facilitar a interação deste pigmento com o solvente etanol, de maior polaridade. Por 
outro lado, o solvente com menor polaridade, hexano, apresentou comportamento oposto e maior afinidade por $\beta$-caroteno.

Estudos que avaliaram o desempenho de misturas de solventes com diferentes polaridades na extração de carotenoides no óleo de FPP ainda são escassos, o que permite inferir que esforços ainda devem ser desprendidos a fim de melhor compreender o desempenho de diferentes solventes na recuperação destes compostos minoritários.

Figura 30 Estrutura molecular de diferentes carotenoides.<smiles>CC(C)=CC=CC(C)=CC=CC=C(C)C=CC=CC(C)=CC=CC1=C(C)CCCC1(C)C</smiles><smiles>CC1=CCCC(C)(C)C1/C=C/C(C)=C/C=C/C(C)=C/C=C/C=C(C)/C=C/C=C(C)/C=C/C1=C(C)CCCC1(C)C</smiles><smiles>CC(C)=CCCC(C)=CC=CC(C)=CC=CC(C)=CC=CC=C(C)C=CC=C(C)C=CC=C(C)CCC=C(C)C</smiles>

Fonte: JORGE, N. Química de lipídeos. In: JORGE, N. 1a ed Química e tecnologia de óleos vegetais. São Paulo: Cultura acadêmica, 2009, $36 \mathrm{p}$.

Vale ressaltar que o teor de carotenoides totais extraídos pela mistura de hexano e etanol foi comparável ao desempenho de hexano puro como pode ser observado na Tabela 19, o que permite concluir que neste caso, o cálculo da Ra (entre a mistura de 
solventes e o soluto $\beta$-caroteno) que definiu a composição da mistura entre hexano e etanol promoveu uma maior extração de carotenoides totais do óleo de FPP.

Os valores de acidez livre analisados nos óleos extraídos em experimentos em batelada e em coluna estão apresentados na Tabela 18.

Por se tratar de um resíduo agroindustrial, os óleos de FPP extraídos por solventes puros e misturas de solventes apresentaram elevado conteúdo de acidez livre, expresso em ácido oleico, e não estão de acordo com a Resolução RDC número 270, da ANVISA (2005), Anexo 14, a qual define os índices máximos de acidez para o óleo bruto de palma em 10,0 mg KOH/g, o que equivale a aproximadamente 5,0 gramas de ácido oleico por 100 gramas de óleo. Dessa forma, para possibilitar o uso deste material, esforços devem ser empreendidos para promover o seu correto acondicionamento após a extração do óleo de palma. Além disso, como uma outra alternativa ao refino físico deste óleo, sugere-se o refino por destilação molecular (MARTINELLO; GONZALO; PRAMPARO, 2007; MARTINS et al. 2006) metodologia que preserva grande parte dos carotenoides no óleo refinado.

Nos experimentos em batelada, dentre todos os solventes estudados, o ciclohexano se destacou por extrair óleo de FPP com menor acidez livre, enquanto que os teores de ácidos graxos livres nos óleos obtidos com os solventes heptano e hexano foram semelhantes, estando em concordância com valores obtidos por Conkerton et al. (1995) para extração de óleo de algodão utilizando os mesmos solventes.

Com base nas análises estatísticas dos dados experimentais obtidos, pode-se inferir que devido a menor polaridade conferida pelos solventes hidrocarbonetos puros e suas respectivas misturas com solventes alcoólicos, foi possível obter óleos de FPP com menores teores de acidez livre quando comparado aos solventes alcoólicos puros, etanol e isopropanol, que extraíram a maior acidez livre, em torno de $19 \%$.

Capellini et al. (2017) obtiveram valores próximos de extração de acidez livre de óleo bruto de farelo de arroz, com etanol (19, $9 \pm 0,4 \%$ ) e isopropanol $(20,11 \pm 0,06 \%)$ expresso em ácido oleico. Valores menores de acidez livre, expressa em ácido oleico, 
foram obtidos por Navarro (2016) na extração de óleo de gérmen de milho, utilizando etanol (15 $\pm 1 \%)$ e isopropanol $(14,5 \pm 0,3 \%)$.

Nos experimentos em coluna, o solvente etanol extraiu óleo com maior teor de acidez livre seguido por hexano, isopropanol e a mistura de hexano e etanol que apresentaram dados estatisticamente iguais. Em comparação com os dados em batelada, os valores de acidez livre apresentaram um leve acréscimo com o uso das misturas de hexano e os solventes alcoólicos.

Como pode ser observado nas Tabelas 10 e 12, o solvente etanol também extraiu o maior conteúdo de água e teor de sólidos solúveis para a fase extrato, respectivamente. Essa capacidade superior do etanol em extrair acidez livre, água e sólidos solúveis observada neste estudo está de acordo com diversos trabalhos na literatura e relaciona-se ao aumento da polaridade demonstrada pelos solventes alcoólicos (JOHNSON e LUSAS, 1983; REGITANO-D'ARCE et al., 1994; NAGENDRA PRASAD et al., 2011; TODA et al., 2016).

$\mathrm{Na}$ Tabela 20 estão reportadas as composições em ácidos graxos do óleo de FPP obtido da extração a frio proposta por Neoh et al. (2011), bem como os resultados obtidos utilizando diferentes solventes puros e misturas de solventes para extrações em batelada e em coluna. Estes dados podem também ser comparados aos valores obtidos na literatura.

Como pode ser observado na Tabela 20, em termos de composição em ácidos graxos, o óleo de FPP extraído a frio apresentou-se rico em ácidos oleico, palmítico e láurico. Estes resultados, quando comparados os valores obtidos por Choo et al. (1996) e Neoh et al. (2011) mostram que o óleo de FPP obtido neste trabalho apresenta elevado conteúdo de ácido láurico o que permite inferir sobre uma possível contaminação com palmiste. Neste contexto, vale ressaltar que durante o preparo da FPP para os experimentos de extração tomou-se o cuidado de separar as sementes de palmiste, as quais estavam aderidas ao material fibroso. Ademais, pequenas diferenças na composição em ácidos graxos observadas podem ser oriundas da origem da 
matéria-prima, do tipo de solo e cultivo e até mesmo do modo de plantio aplicado (GRAMPONE, 2005).

O emprego de solventes puros e misturas de solventes não resultou em diferenças significativas na composição em ácidos graxos dos óleos extraídos, e nos valores de massa molar média, índice de iodo e a razão entre ácidos graxos insaturados e saturados, apresentados na Tabela 21, tanto em experimentos em batelada quanto em coluna. 
Tabela 20 Composição em ácidos graxos do óleo de FPP extraído com solventes puros e misturas de solventes.

\begin{tabular}{|c|c|c|c|c|c|c|c|c|c|c|c|c|c|c|}
\hline & \multirow[t]{2}{*}{$\begin{array}{l}\text { Ácidos } \\
\text { graxos }\end{array}$} & \multirow[t]{2}{*}{ Capróico } & Caprílico & \multirow[t]{2}{*}{ Cáprico } & \multirow[t]{2}{*}{ Láurico } & \multirow[t]{2}{*}{ Mirístico } & \multirow[t]{2}{*}{ Palmítico } & \multirow{2}{*}{\multicolumn{2}{|c|}{$\begin{array}{c}\text { Esteárico Oléico } \\
\text { Cx:y* }\end{array}$}} & \multirow[t]{2}{*}{ Linoléico } & \multirow[t]{2}{*}{ Linolênico } & \multirow[t]{2}{*}{ Araquídico } & \multirow[t]{2}{*}{ Eicosanóico } & \multirow[t]{2}{*}{ Lignocérico } \\
\hline & & & & & & & & & & & & & & \\
\hline & $\begin{array}{l}\text { mistura de } \\
\text { solventes }\end{array}$ & C6:0 & C8:0 & C10:0 & C12:0 & $\mathrm{C} 14: 0$ & $\mathrm{C} 16: 0$ & C18:0 & C18:1 & C18:2 & C18:3 & C20:0 & C20:1 & $\mathrm{C} 24: 0$ \\
\hline & Hexano $^{a}$ & $\begin{array}{l}1,38 \pm \\
0,01^{c}\end{array}$ & $\begin{array}{l}1,39 \pm \\
0,04^{c}\end{array}$ & - & $\begin{array}{c}20,8 \pm \\
0,4^{\mathrm{b}}\end{array}$ & $\begin{array}{l}7,6 \pm \\
0,1^{\text {bcd }}\end{array}$ & $25,3 \pm 0,3^{\mathrm{a}}$ & $\begin{array}{l}3,6 \pm \frac{ \pm}{a b} \\
0,1^{a b}\end{array}$ & $\begin{array}{l}32,6 \pm \\
0,4^{\mathrm{ab}}\end{array}$ & $\begin{array}{l}6,7 \pm \\
0,2 \text { cde }\end{array}$ & - & $\begin{array}{l}0,17 \pm \\
0,03^{\mathrm{ab}}\end{array}$ & $0,4 \pm 0,1^{c}$ & $\begin{array}{l}0,15 \pm \\
0,04^{\mathrm{cd}}\end{array}$ \\
\hline & Etanol & $\begin{array}{l}1,45 \pm \\
0,08^{c}\end{array}$ & $\begin{array}{c}1,40 \\
\pm 0,01^{\mathrm{C}}\end{array}$ & - & $\begin{array}{l}20,6 \pm \\
0,8^{\mathrm{b}}\end{array}$ & $\begin{array}{l}7,4 \pm \pm \\
0,1^{\text {cd }}\end{array}$ & $24,8 \pm 0,4^{a}$ & $3,7 \pm 0,7^{\mathrm{a}}$ & $\begin{array}{l}32,44 \pm \\
0,07^{\mathrm{ab}}\end{array}$ & $\begin{array}{l}7,0 \pm \\
0,2^{\mathrm{bcd}}\end{array}$ & - & $\begin{array}{l}0,19 \pm \\
0,02^{2 \mathrm{ab}}\end{array}$ & $0,76 \pm 0,02^{b}$ & $\begin{array}{l}0,20 \pm \\
0,01^{\mathrm{abc}}\end{array}$ \\
\hline & Isopropanol & $\begin{array}{l}1,40 \pm \\
0,03^{c}\end{array}$ & $\begin{array}{l}1,35 \pm \\
0,04^{c}\end{array}$ & - & $\begin{array}{c}20,3 \pm \\
0,7^{\mathrm{b}}\end{array}$ & $\begin{array}{l}7,41 \pm \\
0,03^{\mathrm{cd}}\end{array}$ & $25,1 \pm 0,5^{\mathrm{a}}$ & $\begin{array}{l}3,6 \pm \\
0,1^{\mathrm{ab}}\end{array}$ & $\begin{array}{l}32,4 \pm \\
0,4^{\mathrm{ab}}\end{array}$ & $\begin{array}{l}7,35 \pm \\
0,03^{\mathrm{bc}}\end{array}$ & - & $\begin{array}{l}0,24 \pm \\
0,03^{\mathrm{a}}\end{array}$ & $0,73 \pm 0,02^{b c}$ & $\begin{array}{l}0,19 \pm \\
0,01^{\mathrm{abc}}\end{array}$ \\
\hline & Hexano & $\begin{array}{l}1,24 \pm \\
0,06^{c}\end{array}$ & $\begin{array}{l}1,29 \pm \\
0,04^{c}\end{array}$ & - & $\begin{array}{l}19,9 \pm \\
0,8^{\mathrm{b}}\end{array}$ & $\begin{array}{l}7,4 \pm \\
0,3^{\text {cd }}\end{array}$ & $24,1 \pm 0,6^{\mathrm{ab}}$ & $\begin{array}{l}3,5 \pm \\
0,1^{\mathrm{ab}}\end{array}$ & $33 \pm 1^{\mathrm{a}}$ & $8,4 \pm 0,6^{a}$ & - & $\begin{array}{l}0,24 \pm \\
0,01^{a}\end{array}$ & $0,44 \pm 0,04^{b c}$ & $\begin{array}{l}0,19 \pm \\
0,02^{\mathrm{abc}}\end{array}$ \\
\hline & Heptano & $1,5 \pm 0,2^{c}$ & $\begin{array}{l}1,45 \pm \\
0,05^{\mathrm{c}}\end{array}$ & - & $\begin{array}{l}22,1 \pm \\
0,1^{\mathrm{f}}\end{array}$ & $\begin{array}{l}7,5 \pm \\
0,4^{\text {cd }}\end{array}$ & $24,6 \pm 0,6^{a}$ & $\begin{array}{l}3,4 \pm \\
0,4^{\mathrm{ab}}\end{array}$ & $\begin{array}{l}31,6 \pm \\
0,4^{\mathrm{ab}}\end{array}$ & $\begin{array}{l}6,6 \pm \\
0,2^{\text {cde }}\end{array}$ & - & $\begin{array}{l}0,29 \pm \\
0,01^{\mathrm{a}}\end{array}$ & $0,38 \pm 0,09^{c}$ & $\begin{array}{l}0,15 \pm \\
0,04^{\frac{d d}{d}}\end{array}$ \\
\hline & Ciclohexano & $\begin{array}{l}2,24+\frac{t}{b} \\
0,09^{b}\end{array}$ & $\begin{array}{l}1,36 \pm \\
0,02^{c}\end{array}$ & - & $\begin{array}{c}20,97 \pm \\
0,08^{\mathrm{b}}\end{array}$ & $\begin{array}{l}7,49 \pm \\
0,07^{\mathrm{cd}}\end{array}$ & $25,0 \pm 0,2^{\mathrm{a}}$ & $\begin{array}{l}3,4+\frac{ \pm}{a b} \\
0,1^{a b}\end{array}$ & $\begin{array}{l}32,3 \pm \\
0,2^{\mathrm{ab}}\end{array}$ & $\begin{array}{l}6,5 \pm \\
0,2^{\mathrm{de}}\end{array}$ & - & $\begin{array}{l}0,19 \pm \\
0,01^{\mathrm{ab}}\end{array}$ & $0,39 \pm 0,01^{\mathrm{C}}$ & $\begin{array}{l}0,18 \pm \\
0,03^{\mathrm{abc}}\end{array}$ \\
\hline \multirow[t]{6}{*}{ Batelada } & $\begin{array}{l}\text { Hexano e } \\
\text { Etanol }\end{array}$ & $2,0 \pm 0,5^{b}$ & $2,0 \pm 0,5^{b}$ & - & $31 \pm 1^{\mathrm{a}}$ & $\begin{array}{l}8,2 \pm \\
0,07^{\mathrm{ab}}\end{array}$ & $\begin{array}{l}20,9 \pm \\
0,1^{\mathrm{bcd}}\end{array}$ & $\begin{array}{l}2,6 \pm \\
0,03^{\mathrm{cd}}\end{array}$ & $24 \pm 1^{d}$ & $\begin{array}{c}7,2 \pm \\
0,08^{\mathrm{bcd}}\end{array}$ & - & $\begin{array}{l}0,16 \pm \\
0,07^{\mathrm{ab}}\end{array}$ & $0,71 \pm 0,06^{b c}$ & $\begin{array}{l}0,16 \pm \\
0,01^{\text {bcd }}\end{array}$ \\
\hline & $\begin{array}{l}\text { Hexano e } \\
\text { Isopropanol }\end{array}$ & $\begin{array}{l}1,38 \pm \\
0,01^{c}\end{array}$ & $\begin{array}{l}1,36 \pm \\
0,03^{\mathrm{c}}\end{array}$ & - & $\begin{array}{c}20,8 \pm \\
0,6^{\mathrm{b}}\end{array}$ & $\begin{array}{l}7,7 \stackrel{ \pm}{ \pm} \\
0,02^{\mathrm{bcd}}\end{array}$ & $\begin{array}{c}25,1 \pm \\
0,04^{\mathrm{a}}\end{array}$ & $\begin{array}{l}3,43 \pm \\
0,06^{2 \mathrm{ab}}\end{array}$ & $32 \pm 1^{a b}$ & $\begin{array}{l}7,04 \pm \\
0,01^{\text {bcd }}\end{array}$ & - & $\begin{array}{l}0,20 \pm \\
0,02^{\mathrm{ab}}\end{array}$ & $0,65 \pm 0,01^{\mathrm{bc}}$ & $0,22 \pm 0,01^{a}$ \\
\hline & $\begin{array}{l}\text { Heptano e } \\
\text { Etanol }\end{array}$ & $\begin{array}{l}1,36 \pm \\
0,04^{\mathrm{c}}\end{array}$ & $\begin{array}{l}1,33 \pm \\
0,08^{c}\end{array}$ & - & $\begin{array}{l}20,8 \pm \\
0,09^{\mathrm{b}}\end{array}$ & $\begin{array}{l}7,4 \pm \\
0,03^{\mathrm{cd}}\end{array}$ & $26 \pm 1^{\mathrm{a}}$ & $\begin{array}{l}3,07 \pm \\
0,08^{\mathrm{abc}}\end{array}$ & $\begin{array}{c}32,5 \pm \\
0,1^{\mathrm{ab}}\end{array}$ & $\begin{array}{l}6,85 \pm \\
0,01^{\text {cde }}\end{array}$ & - & $\begin{array}{l}0,16 \pm \\
0,04^{\mathrm{ab}}\end{array}$ & $0,61 \pm 0,05^{b c}$ & $\begin{array}{l}0,18 \pm \\
0,02^{\mathrm{abc}}\end{array}$ \\
\hline & $\begin{array}{l}\text { Heptano e } \\
\text { Isopropanol }\end{array}$ & $\begin{array}{l}1,51 \pm \\
0,09^{c}\end{array}$ & $\begin{array}{l}1,53 \pm \\
0,08^{c}\end{array}$ & - & $22 \pm 1^{b}$ & $\begin{array}{c}7,9 \pm \\
0,02^{\mathrm{abc}}\end{array}$ & $24,3 \pm 0,5^{a}$ & $\begin{array}{l}3,2 \pm \\
0,2^{\mathrm{ab}}\end{array}$ & $\begin{array}{c}31,1 \pm \\
0,9^{\mathrm{bc}}\end{array}$ & $\begin{array}{l}7,0 \pm \\
0,02^{\mathrm{bcd}}\end{array}$ & - & $\begin{array}{l}0,17 \pm \\
0,01^{ \pm \frac{b}{b}}\end{array}$ & $0,68 \pm 0,02^{b c}$ & $\begin{array}{l}0,21 \pm \\
0,01^{\frac{\mathrm{ab}}{\mathrm{b}}}\end{array}$ \\
\hline & $\begin{array}{c}\text { Ciclohexano e } \\
\text { Etanol }\end{array}$ & $\begin{array}{l}2,35 \pm \\
0,01^{\mathrm{ab}}\end{array}$ & $\begin{array}{l}1,28 \pm \\
0,01^{\mathrm{c}}\end{array}$ & - & $\begin{array}{l}20,2 \pm \\
0,3^{\mathrm{b}}\end{array}$ & $\begin{array}{l}7,2 \pm \\
0,01^{d}\end{array}$ & $\begin{array}{l}25,0 \pm \\
0,01^{\mathrm{a}}\end{array}$ & $\begin{array}{l}3,27 \pm \pm \\
0,06^{2 \mathrm{ab}}\end{array}$ & $\begin{array}{l}32,8 \pm \\
0,3^{\mathrm{ab}}\end{array}$ & $\begin{array}{l}6,82 \pm \\
0,03^{\text {bcd }}\end{array}$ & - & $\begin{array}{l}0,20 \pm \\
0,03^{\mathrm{ab}}\end{array}$ & $0,62 \pm 0,06^{b c}$ & $\begin{array}{l}0,19 \pm \\
0,03^{\mathrm{abc}}\end{array}$ \\
\hline & $\begin{array}{l}\text { Ciclohexano e } \\
\text { Isopropanol }\end{array}$ & $\begin{array}{l}2,39 \pm+ \\
0,08^{\mathrm{ab}}\end{array}$ & $\begin{array}{l}1,49 \pm \\
0,01^{c}\end{array}$ & - & $\begin{array}{l}22,2 \pm \\
0,3^{\mathrm{b}}\end{array}$ & $\begin{array}{l}7,72 \pm \\
0,04^{\text {bcd }}\end{array}$ & $\begin{array}{l}23,2 \pm \\
0,3^{\mathrm{abc}}\end{array}$ & $\begin{array}{l}2,99 \pm \\
0,06^{\text {bcd }}\end{array}$ & $\begin{array}{l}31,7 \pm \pm \\
0,1^{\mathrm{ab}}\end{array}$ & $\begin{array}{l}7,2 \pm \pm \\
0,1\end{array}$ & - & $\begin{array}{l}0,18 \pm \\
0,02^{\mathrm{ab}}\end{array}$ & $0,8 \pm 0,1^{b}$ & $\begin{array}{l}0,17 \pm \pm \pm \\
0,01^{\mathrm{abc}}\end{array}$ \\
\hline
\end{tabular}


Continuação Tabela 20 Composição em ácidos graxos do óleo de FPP extraído com solventes puros e misturas de solventes.

\begin{tabular}{|c|c|c|c|c|c|c|c|c|c|c|c|c|c|c|}
\hline & Etanol & $\begin{array}{l}1,62 \pm \\
0,01^{c}\end{array}$ & $\begin{array}{l}1,46 \pm \\
0,07^{c}\end{array}$ & - & $21,8 \pm 0,2^{b}$ & $\begin{array}{l}7,3 \pm \\
0,2^{\text {cd }}\end{array}$ & $23,8 \pm 0,2^{a b c}$ & $\begin{array}{l}3,2 \pm \\
0,1^{a b}\end{array}$ & $\begin{array}{c}31,63 \pm \\
0,32^{\mathrm{ab}}\end{array}$ & $7,6 \pm 0,3^{b}$ & - & $\begin{array}{l}0,20 \pm \\
0,02^{a b}\end{array}$ & $1,3 \pm 0,06^{a}$ & $\begin{array}{l}0,17 \pm \\
0,01^{\text {bcd }}\end{array}$ \\
\hline & Isopropanol & $1,4 \pm 0,2^{c}$ & $1,5 \pm 0,2^{c}$ & - & $22 \pm 2^{b}$ & $\begin{array}{l}7,7 \pm \\
0,3^{\mathrm{bcd}}\end{array}$ & $25,0 \pm 0,6^{a}$ & $\begin{array}{l}3,3 \pm \\
0,1^{a b}\end{array}$ & $31 \pm 1^{\mathrm{bc}}$ & $\begin{array}{l}7,0 \pm \\
0,2^{\text {bcd }}\end{array}$ & - & $\begin{array}{l}0,19 \pm \\
0,02^{a b}\end{array}$ & $0,72 \pm 0,01^{b c}$ & $\begin{array}{l}0,19 \pm \\
0,02^{a b c}\end{array}$ \\
\hline \multirow[t]{5}{*}{ Coluna } & Hexano & $\begin{array}{l}1,25 \pm \\
0,01^{c}\end{array}$ & $\begin{array}{l}1,34 \pm \\
0,03^{c}\end{array}$ & - & $\begin{array}{c}20,9 \pm \\
0,04^{\mathrm{b}}\end{array}$ & $\begin{array}{l}7,7 \pm \\
0,1^{\mathrm{bcd}}\end{array}$ & $25,4 \pm 0,2^{a}$ & $\begin{array}{l}3,5 \pm \\
0,01^{a b}\end{array}$ & $32,6 \pm 0,1^{\mathrm{ab}}$ & $\begin{array}{l}6,6 \pm \\
0,2^{\text {cde }}\end{array}$ & - & $\begin{array}{l}0,21 \pm \\
0,02^{a b}\end{array}$ & $0,42 \pm 0,03^{b c}$ & $0,21 \pm 0,01^{a}$ \\
\hline & $\begin{array}{l}\text { Hexano e } \\
\text { Etanol }\end{array}$ & $2,7 \pm 0,3^{a}$ & $2,6 \pm 0,3^{a}$ & - & $32 \pm 2^{a}$ & $\begin{array}{c}8,4 \pm \\
0,3^{a}\end{array}$ & $19 \pm 1^{d}$ & $1,9 \pm 0,1^{\mathrm{e}}$ & $26 \pm 1^{d}$ & $\begin{array}{l}6,7 \pm \\
0,2^{\text {cde }}\end{array}$ & - & $\begin{array}{l}0,11 \pm \\
0,03^{\mathrm{b}}\end{array}$ & $0,73 \pm 0,04^{b c}$ & $0,09 \pm 0,01^{\mathrm{e}}$ \\
\hline & $\begin{array}{c}\text { Hexano e } \\
\text { Isopropanol }\end{array}$ & $2,0 \pm 0,3^{b}$ & $1,9 \pm 0,1^{b}$ & - & $28 \pm 2^{a}$ & $\begin{array}{l}8,2 \pm \\
0,1^{a b}\end{array}$ & $21 \pm 2^{\mathrm{cd}}$ & $2,5 \pm 0,5^{d}$ & $30 \pm 2^{c}$ & $6,0 \pm 0,5^{\mathrm{e}}$ & - & $\begin{array}{l}0,14 \pm \\
0,04^{\mathrm{b}}\end{array}$ & $0,64 \pm 0,01^{b c}$ & $\begin{array}{l}0,12 \pm \\
0,05^{\mathrm{de}}\end{array}$ \\
\hline & Literatura $^{\mathrm{a}}$ & - & - & - & $5,9 \pm 0,2$ & $2,6 \pm 0,1$ & $39,34 \pm 0,09$ & $3,6 \pm 0,1$ & $37,74 \pm 0,08$ & $\begin{array}{c}10,00 \pm \\
0,04\end{array}$ & - & - & - & - \\
\hline & Literatura $^{\mathrm{b}}$ & traços & 1,8 & 1,3 & 13,8 & 6,2 & 33,9 & 3,3 & 31,7 & 7,1 & 0,6 & 0,1 & - & - \\
\hline
\end{tabular}

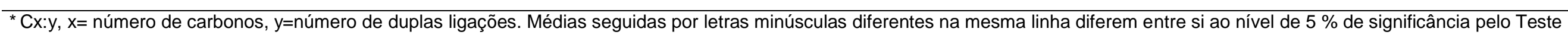

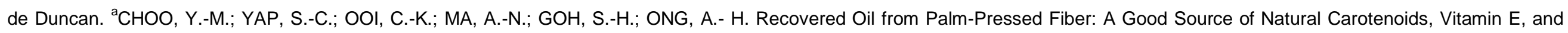

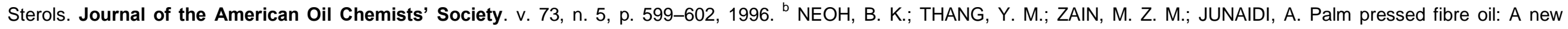
opportunity for premium hardstock? International Food Research Journal, v. 18, n. 2, p. 769-773, 2011. Fonte: Própria autoria. 
Tabela 21 Composições do óleo de FPP extraído com solventes e misturas de solventes.

\begin{tabular}{|c|c|c|c|c|}
\hline & $\begin{array}{c}\text { Solventes e misturas de } \\
\text { solventes }\end{array}$ & Insat/sat & Índice de iodo & MM média (g.mol $\left.{ }^{-1}\right)$ \\
\hline & Hexano* & $0,657 \pm 0,003^{b}$ & $39,91 \pm 0,09^{b c}$ & $243,2 \pm 0,5^{\mathrm{abc}}$ \\
\hline & Etanol & $0,673 \pm 0,004^{b}$ & $40,7 \pm 0,3^{b c}$ & $243,4 \pm 0,9^{\mathrm{abc}}$ \\
\hline & Isopropanol & $0,68 \pm 0,01^{\mathrm{ab}}$ & $41,2 \pm 0,4^{\mathrm{bc}}$ & $243,9 \pm 0,6^{\mathrm{ab}}$ \\
\hline & Hexano & $0,73 \pm 0,05^{a}$ & $44 \pm 2^{\mathrm{a}}$ & $245 \pm 1^{\mathrm{a}}$ \\
\hline & Heptano & $0,630 \pm 0,003^{b}$ & $39,0 \pm 0,1^{c}$ & $241,94 \pm 0,05^{\mathrm{abcd}}$ \\
\hline & Ciclohexano & $0,644 \pm 0,001^{b}$ & $39,3 \pm 0,1^{\mathrm{bc}}$ & $240,7 \pm 0,1^{c d}$ \\
\hline \multirow[t]{8}{*}{ Batelada } & Hexano e Etanol & $0,485 \pm 0,002^{d}$ & $35 \pm 1^{\text {de }}$ & $232 \pm 2^{f}$ \\
\hline & Hexano e Isopropanol & $0,66 \pm 0,03^{b}$ & $40,3 \pm 0,9^{\mathrm{bc}}$ & $243,3 \pm 0,8^{\mathrm{abc}}$ \\
\hline & Heptano e Etanol & $0,666 \pm 0,005^{b}$ & $40,3 \pm 0,2^{b c}$ & $244 \pm 1^{\mathrm{abc}}$ \\
\hline & Heptano e Isopropanol & $0,63 \pm 0,03^{b}$ & $39 \pm 1^{\mathrm{bc}}$ & $242 \pm 2^{\mathrm{bcd}}$ \\
\hline & Ciclohexano e Etanol & $0,67 \pm 0,01^{\mathrm{b}}$ & $40,5 \pm 0,3^{\mathrm{bc}}$ & $241,3 \pm 0,3^{\mathrm{bcd}}$ \\
\hline & Ciclohexano e Isopropanol & $0,657 \pm 0,003^{b}$ & $40,3 \pm 0,2^{b c}$ & $239,251 \pm 0,002^{d}$ \\
\hline & Etanol & $0,68 \pm 0,02^{a b}$ & $41,4 \pm 0,07^{b}$ & $242,2 \pm 0,3^{\mathrm{abcd}}$ \\
\hline & Isopropanol & $0,64 \pm 0,04^{b}$ & $39 \pm 2^{b c}$ & $242 \pm 3^{\mathrm{abcd}}$ \\
\hline \multirow[t]{3}{*}{ Coluna } & Hexano & $0,66 \pm 0,01^{b}$ & $39,8 \pm 0,4^{\mathrm{bc}}$ & $243,6 \pm 0,2^{\mathrm{abc}}$ \\
\hline & Hexano e Etanol & $0,50 \pm 0,03^{d}$ & $34 \pm 1^{\mathrm{e}}$ & $229 \pm 3^{g}$ \\
\hline & Hexano e Isopropanol & $0,57 \pm 0,02^{c}$ & $36,4 \pm 0,4^{d}$ & $235 \pm 2^{e}$ \\
\hline
\end{tabular}

*NEOH, B. K.; THANG, Y. M.; ZAIN, M. Z. M.; JUNAIDI, A. Palm pressed fibre oil: A new opportunity for premium hardstock? International Food Research Journal, v. 18, n. 2, p. 769-773, 2011. Fonte: Própria autoria. 


\section{CONCLUSÕES}

A busca pelo sinergismo entre diferentes solventes com diferentes polaridades, com composições previamente definidas pelo cálculo da distância soluto-solvente, para a obtenção de um óleo de FPP rico em carotenoides pode ter sido dificultada devido, possivelmente, a estrutura física da FPP. A FPP apresenta uma baixa densidade que interfere nos processos de extração sólido-líquido. De fato, nos experimentos de extração em batelada, para encharcar toda a FPP foi necessário uma grande quantidade, em massa, de solvente, o que industrialmente, em termos de energia para posterior recuperação deste solvente, geraria um excessivo custo operacional.

Os experimentos de extração em batelada na razão sólido:solvente de 1:7 resultaram em elevado rendimento de extração de óleo para todos os solventes empregados, em torno de $70 \%$ (em massa), no entanto, o solvente hexano e a mistura compreendida por heptano e isopropanol, extraíram o maior conteúdo de óleo de FPP, aproximadamente $80 \%$ (em massa). Adicionalmente, elevados conteúdos de carotenoides foram recuperados com a utilização de hexano e ciclohexano. Já nos experimentos de extração sólido-líquido em coluna, utilizando menor razão sólido:solvente, de 1:4, os maiores rendimentos de extração de óleo de FPP foram obtidos com o emprego de etanol e da mistura compreendida por hexano e isopropanol, em torno de $66 \%$ (em massa).

Conclui-se que os solventes hidrocarbonetos e suas misturas com os álcoois de cadeia curta, etanol e isopropanol, definidas a partir do cálculo da distância solutosolvente $(\mathrm{Ra})$, demonstraram boa capacidade em extrair óleo de FPP rico em carotenoides, mantendo sua composição em ácidos graxos e acidez livre relativamente constante. Ademais, os baixos valores de índice de retenção aliados aos menores valores de transferência de água para a fase extrato obtidos com o emprego destes solventes, impactam positivamente as etapas de extração sólido-líquido industriais, 
facilitando as operações subsequentes de dessolventização das fases extrato e rafinado.

É importante ressaltar que neste estudo, os álcoois de cadeia curta etanol e isopropanol apresentaram resultados satisfatórios, principalmente em relação ao rendimento de extração de óleo, o que denota um potencial desempenho em processos de extração de óleo de FPP por estes solventes. As misturas propostas permitem a substituição parcial dos solventes hidrocarbonetos pelos álcoois de cadeia curta sem perdas significativas de rendimento de extração de óleo e de carotenoides e no caso da mistura de hexano e etanol, permite também obter um conteúdo de carotenoides totais equivalente ao total extraído por hexano puro. 


\section{SUGESTÕES PARA TRABALHOS FUTUROS}

Uma vez que o cálculo da distância entre o soluto de interesse e o solvente ou misturas de solventes é uma abordagem inovadora do ponto de vista da obtenção da máxima solubilização desejada, este estudo deve ser ainda mais bem investigado e empregado para outras potenciais matérias-primas oleaginosas, com foco na obtenção de óleos ricos em compostos minoritários com atividade antioxidante ou pró-vitamínica.

Faz-se necessário também o estudo da viabilidade técnica do emprego da mistura dos solventes heptano e isopropanol, em experimentos em coluna empacotada de leito fixo, uma vez que esta mistura de solventes apresentou um ótimo desempenho em relação ao rendimento de extração de óleo em experimentos em batelada, no entanto, não foi possível seu estudo devido à escassez de matéria-prima ao final do mestrado.

O conteúdo de ácido láurico encontrado nos óleos de FPP extraídos com solventes puros e misturas de solventes deve ser mais bem estudado uma vez que este componente contribui para geração de produtos com elevado valor agregado, com possível aplicação tanto na indústria farmacêutica como na indústria de alimentos.

Por fim, são necessários estudos posteriores acerca da análise de viabilidade econômica do processo de extração e refino do óleo de FPP a fim de quantificar os possíveis lucros que a indústria produtora de óleo de palma poderia ter ao deixar de utilizar este valioso subproduto como gerador de energia em caldeiras. 
8 REFERÊNCIAS

ALFONSI, K.; COLBERG, J.; DUNN, P. J.; FEVIG, T.; JENNINGS, S.; JOHNSON, T. A.; KLEINE, H. P.; KNIGHT, C.; NAGY, M. A.; PERRY, D. A.; STEFANIAK, M. Green chemistry tools to influence a medicinal chemistry and research chemistry based organization. Green Chemistry, v. 10, n. 1, p. 31-36, 2008.

ANDERSON, D. A Primer on Oils Processing Technology. 6th ed. In: SHAHIDI, F. Bailey's Industrial Oil and Fat Products. New Jersey: John Wiley and Sons, 2005, p. $1-56$.

ANSOLIN, M. Análise da distribuição de componentes minoritários de óleos vegetais em dados de equilíbrio líquido-líquido de sistemas graxos. Tese de doutorado. Universidade Estadual de Campinas, 2017.

ANVISA. Resolução RDC $\mathrm{n}^{\circ}$ 270, de 22 de setembro de 2005. Disponível em: <http://portal.anvisa.gov.br/wps/wcm/connect/a2190900474588939242d63fbc4c6735/R DC_482_1999.pdf?MOD=AJPERES>. Acesso em: 10 nov. 2017.

A.O.A.C. Official methods of analysis. 18th ed. Washington, D.C.: A.O.A.C., 2007.

A.O.C.S. Official methods and recommended practices of the American Oil Chemists' Society, Press, 3rd ed. Champaign, v.1-2, 1998.

A.O.C.S. Official methods and recommended practices of the AOCS. 6th ed. Champaign: AOCS Press, 2009.

APTEL, P.; CHALLARD, N.; CUNY, J.; NELL, J. Application of the pervaporation process to separate azeotropic mixtures. Journal of Membrane Science, v.1, p. 271287, 1976.

ASAE. Method of Determining and Expressing Fineness of Feed Materials. Sieving St. Joseph, MIASABE, 2008.

ASP, N. G.; CLAES, G. J.; HALLMER, H.; SILJESTRON, M. Rapid enzymatic assay of insoluble and soluble dietary fiber. Journal of Agricultural and Food Chemistry, Bethesda, v. 31, n. 3, p. 476-482, 1983.

BARTON, A. F. M. Handbook of solubility parameters end other cohesion parameters. Boca Raton: CRC press, 1983. 
BASIRON, Y. Palm Oil. In: SHAHIDI, F. 6th ed. Bailey's industrial oil and fat products. New Jersey: John Wiley \& Sons, Inc., 2005. p. 333-429.

BATISTA, M. M.; GUIRARDELLO, R.; KRÄHENBÜHL, M. A. Determination of Hansen Solubility Parameters of Vegetable Oils, Biodiesel, Diesel, and Biodiesel-Diesel Blends. Journal of American Oil Chemists' Society. v. 92, p. 95-109, 2015.

BELITZ, H. D.; GROSCH, W.; SCHIEBERLE, P. Food Chemistry. Springer-Verlag: Berlim, 2004.

BERGER, K.G., Palm Oil. In: Structured and Modified Lipids. GUNSTONE. Marcel Dekker: New York, 2001, p. 119.

BESSA, L. C. B. A. A rota etílica na produção de ésteres graxos: extração de óleo vegetal e modelagem do equilíbrio líquido-líquido. 2016. 183f. Tese (doutorado) Universidade Estadual de Campinas, Faculdade de Engenharia de Alimentos, Campinas, 2016.

BESSA, L. C. B. A.; FERREIRA, M. C.; RODRIGUES, C. E. C.; BATISTA, E. A. C.; MEIRELLES, A. J. A. Simulation and process design of continuous countercurrent ethanolic extraction of rice bran oil. Journal of Food Engineering, v.202, p.99-113, 2017.

$\mathrm{BOSCH}$, E. et al. Solute-solvent and solvent-solvent interactions in binary solvent mixtures. 2. Effect of temperature on the ET(30) polarity parameter of dipolar hydrogen bond acceptor-hydrogen bond donor mixtures. Journal of Physical Organic Chemistry, v. 9, n. 6, p. 403-410, 1996

BOSS, E. A. Análise do desempenho de plantas de extração de óleos convencionais e de processos supercríticos. 2000. 105 f. Dissertação (Mestrado) Faculdade de Engenharia Química, Universidade Estadual de Campinas, Campinas, 2000.

CAPELLINI, M. C.; GIACOMINI, V.; CUEVAS, M. S.; RODRIGUES, C. E. C. Rice bran oil extraction using alcoholic solvents: Physicochemical characterization of oil and protein fraction functionality. Industrial Crops and Products, v. 104, p. 133-143, 2017.

CARPENTER, K. L. H. $\beta$-Carotene: A colorful killer of cancer cells? A commentary on -ROS-triggered caspase 2 activation and feedback amplification loop in $\beta$-caroteneinduced apoptosisll. Free Radical Biology and Medicine, v. 41, n. 3, p. 418-421, 2006. 
CARDENAS-TORO, F. P.; FORSTER-CARNEIRO, T.; ROSTAGNO, M. A.; PETENATE, A. J.; MAUGERI FILHO, F.; MEIRELES, M. A. A. Integrated supercritical fluid extraction and subcritical water hydrolysis for the recovery of bioactive compounds from pressed palm fiber. The Journal of Supercritical Fluids, v. 93, p. 42-48, 2014.

CERUTTI, M. L. M. N.; DE SOUZA, A. A. U.; DE SOUZA, S. M. D. A. G. U. Solvent extraction of vegetable oils: Numerical and experimental study. Food and Bioproducts Processing, v. 90, n. 2, p. 199-204, 2012.

CHOO, Y.-M.; YAP, S.-C.; OOI, C.-K.; MA, A.-N.; GOH, S.-H.; ONG, A.- H. Recovered Oil from Palm-Pressed Fiber: A Good Source of Natural Carotenoids, Vitamin E, and Sterols. Journal of the American Oil Chemists' Society, v. 73, n. 5, p. 599-602, 1996.

CONKERTON, E. J.; WAN, P. J.; RICHARD, O. A. Hexane and heptane as extraction solvents for cottonseed: A laboratory-scale study. Journal of the American Oil Chemists' Society, v. 72, n. 8, p. 963-965, 1995.

COLLARES, C. Disponível em: <https://ainfo.cnptia.embrapa.br/digital/bitstream/item/44255/1/Revista-Agroenergia-21417.pdf>. Acesso em: 13 out. 2017.

DI MASCIO, P.; KAISER, S.; SIES, H. Lycopene as the Most Efficient Biological Carotenoid Singlet Oxygen Quencher. Archives of Biochemistry and Biophysics, v. 274, p. 532-538, 1989.

DI MASCIO, P.; MURPHY, M. E.; SIES, H. Antioxidant defense systems: The role of carotenoids, tocopherols and thiols. American Journal of Clinical Nutrition, v. 53, p. 194-200, 1991.

DOMAŃSKA, U. Solubility of acetyl-substituted naphthols in binary solvent mixtures. Fluid Phase Equilibria, v. 55, n. 1, p. 125-145, 1990.

DUNCAN, D. Multiple range and multiple F tests. Biometrics, v.11, p.1-42, 1955.

FDA. Food and Drug administration. TABLES, Q. C. Guidance for Industry Guidance for Industry. February, 2012.

FERREIRA, B. S.; DE ALMEIDA, C. G.; FAZA, L. P.; DE ALMEIDA, A.; DINIZ, C. G.; DA SILVA, V. L.; GRAZUL, R. M.; LE HYARIC, M. Comparative properties of amazonian oils obtained by different extraction methods. Molecules, v. 16, n. 7, p. 5874-5885, 
2011.

FRANCO, D.; SINEIRO, J.; NÚÑEZ, M.J. Ethanolic extraction or Rosa rubiginosa soluble substances: oil solubility equilibria and kinetic studies. Journal of Food Engineering, Essex, v. 79, n.1, p. 150-157, 2007.

FRANÇA, L. F. Estudo do aproveitamento dos carotenos das fibras resultantes da prensagem na indústria de óleo de palma, pela extração com $\mathrm{CO}_{2}$ supercrítico. 1999.149 p. Tese (doutorado) - Universidade Estadual de Campinas, Campinas, 1999.

GALVIN, J. B.; BOND, G. 2-Methylpentane (isohexane). Journal of Toxicology and Environmental Health, Part A, v. 58, n. 1-2, p. 81-92, 1999.

GANDHI, A. P.; JOSHI, K. C.; JHA, K.; PARIHAR, V. S.; SRIVASTAV, D. C.; RAGHUNADH, P.; KAWALKAR, J.; JAIN, S. K.; TRIPATHI, R. N. Studies on alternative solvents for the extraction of oil-I soybean. International Journal of Food Science and Technology, v. 38, n. 3, p. 369-375, 2003.

GAZIANO, J. M.; MANSON. J. E; FIDKER, P. M.; BURING, J. E.; HENNEKENS, H. Beta-Carotene Therapy for Chronic Stable Angina, paper presented at Annual Meeting of the American Heart Association, Dallas, Texas, 1990.

GLOBO RURAL ONLINE. Disponível em: <http://revistagloborural.globo.com/Revista/Common/0,,EMl188680-18078,00GOVERNO+DIVULGA+ZONEAMENTO+AGRICOLA+DA+PALMA+DE+OLEO.html>. Acesso em: 10 out. 2017.

GMEHLING, L.; MENKE, J.; KRAFCZYK, J.; FISCHER, K.; FONTAINE, J.-C; KEHIAIAN, H. V. Azeotropic data for binary mixtures. 92th ed. In: HAYNES, W. M. CRC handbook of chemistry and physics. Boca Raton: CRC Press, 2012. p. 210-228.

GRAMPONE, M. A. Sunflower oil. Bailey's Industrial oil \& Fat Products. In: SHAHIDI, 2005, v. 2, 655-730 p.

GONZÁLEZ, B.; CALVAR, N.; DOMÍNGUEZ, A.; TOJO, J. Dynamic viscosities of binary mixtures of cycloalkanes with primary alcohols at $T=(293.15,298.15$, and 303.15$) \mathrm{K}$ : New UNIFAC-VISCO interaction parameters. Journal of Chemical Thermodynamics. v. 39, p. 322-334, 2007.

GUNSTONE, F. D. Vegetable Oils in Food Technology: Composition, properties and uses. 2th. ed. John Wiley and Sons: New Jersey, 2011. 
HAMM, W.; HAMILTON, R. J. Edible Oil Processing. Sheffield Press Ltd: U. K., 2000, p. 73-77.

HAMMOND, E.G., JOHNSON, L.A., SU, C., WANG, T., WHITE, P.J.Soybean Oil. In: SHAHIDI, F. Bailey's Industrial Oil and Fat Products. John Wiley and Sons: New Jersey, 2005.

HANMOUNGJAI, P.; PYLE, L.; NIRANJAN, K. Extraction of rice bran oil using aqueous media. Journal of Chemical Technology and Biotechnology, Oxford, v.75, p. 348352, 2000.

HANSEN, C. M. 50 Years with solubility parameters - Past and future. Progress in Organic Coatings, v. 51, n. 1, p. 77-84, 2004.

HARRISON, L.L.N.; NUR, S.W.; CHOO, Y.M. Novel Refining Technology of PalmPressed Fibre Oil. 2013. Disponível em: <http://palmoilis.mpob.gov.my/publications/TOT/TT536.pdf>. Acesso em: 10 Out. 2017.

HILDEBRAND, J.; SCOTT, R. L. The Solubility of Nonelectrolytes. 3 ed th. Reinhold: New York, 1950.

HOJILLA-EVANGELISTA, M. P.; JOHNSON, L. A. Factors affecting oil extraction/water adsorption in sequential extraction processing of corn. Journal of the American Oil Chemists' Society, v. 79, p. 815-823, 2002.

HU, W.; WELLS, J. H.; SHIN, T.; GODBER, J. S. Comparison of isopropanol and hexane for extraction of vitamin $E$ and Oryzanols from stabilized rice bran. Journal of the American Oil Chemists' Society, Chicago, v.73, n.12, p. 1653-1656, 1996.

INDEX MUNDI. Brazil Palm Oil Production by Year. Disponível em: < https://www.indexmundi.com/agriculture/?country=br\&commodity=palmoil\&graph=production>. Acesso em: 07 Fev. 2018.

IUPAC. Standard methods for the analysis of oils, fats and derivatives. 6th ed. part 1 (sections I and II). PAQUOT, C. Oxford: Pergamon Press, 1979.

JOHNSON, L.A.; LUSAS, E.W. Comparison of alternative solvents for oils extraction. Journal of the American Oil Chemists' Society, Chicago, v. 60, p. 229-242, 1983.

JORGE, N. Química de lipídeos. In: JORGE, N. 1th ed Química e tecnologia de óleos vegetais. São Paulo: Cultura acadêmica, 2009, 36 p. 
KAMARUN ZAMAN, H. B. Production of high fibre bread from oil palm pericarp fibre. Bachelor of Science (BSc) Thesis, Faculty of Applied Sciences, Universiti Teknologi MARA, Malaysia.

KELLY-YOUNG, T. L.; LEE, K. T.; MOHAMED, A. R.; BHATIA, S. Potential of hydrogen from oil palm biomass as a source of renewable energy wordwide. Energy Policy. $v$. 35, p. 5692-5701, 2007.

KEMPER, T. G. Oil Extraction. In: SHAHIDI, F. 6.eth. Bailey's industrial oil and fat products. 6th ed. New Jersey: John Wiley \& Sons, Inc., 2005. v.5, p. 71-72.

LAI, O. M. Palm Oil, Its Fractions, and Components. Healthful Lipids, n. 1, 2005.

LAU, H. L. N.; CHOO, Y. M.; MA, A. N.; CHUAH, C.H. Quality of residual oil from palmpressed mesocarp fiber (Elaeis guineensis) using supercritical CO2 with and without ethanol. Journal of the American Oil Chemists' Society, v. 83, n. 10, p. 893-898, 2006.

LAU, H. L. N.; CHOO, Y. M.; MA, A. N.; CHUAH, C.H. Selective extraction of palm carotene and vitamin $E$ from fresh palm-pressed mesocarp fiber (Elaeis guineensis) using supercritical CO2. Journal of Food Engineering, v. 84, n. 2, p. 289-296, 2008.

LI, Y.; FINE, F.; FABIANO-TIXIER, A. S.; ABERT-VIAN, M.; CARRE, P.; PAGES, X.; CHEMAT, F. Evaluation of alternative solvents for improvement of oil extraction from rapeseeds. Comptes Rendus Chimie, v. 17, n. 3, p. 242-251, 2014.

LIN, C. H.; CHEN, B. H. Determination of carotenoids in tomato juice by liquid chromatography. Journal of chromatography A. v. 1012, n. 1, p. 103-9, 2003.

LIAAEN-JENSEN, S. Carotenoid antioxidant. In: KRINSKY, N. I.; MAYNE, S. T.; SIES, H. Carotenoids in Healthy and Disease. Marcel Dekker: New York, 2004.

LONG, R. D.; ABDELKADER, E. Mixed-polarity azeotropic solvents for efficient extraction of lipids from nannochloropsis microalgae. American Journal of Biochemistry and Biotechnology, v. 7, n. 2, p. 70-73, 2011.

MAJUMDAR, G. C.; SAMANTA, A. N.; SENGUPTA, S. P. Modeling solvent extraction of vegetable oil in a packed bed. Journal of the American Oil Chemists' Society, v. 72 , n. 9, p. 971-979, 1995.

MAMIDIPALLY, P. K.; LIU, S. First approach on rice bran oil extraction using Limonene. 
European Food Research and Technology, Berlin, v.106, p.122-125, 2004.

MARCILLA, A.; RUIZ, F.; GARCI'A, A. N. Liquid-liquid-solid equilibria of the quaternary system water-ethanol-acetone-sodium chloride at 25_C. Fluid Phase Equilibria, v. 112, p.273-289, 1995.

MARTINELLO, M.; GONZALO, H.; PRAMPARO, M. D. C. Grape seed oil deacidification by molecular distillation: Analysis of operative variables influence using the response surface methodology. Journal of Food Engineering. v. 81, n. 1, p. 60-64, 2007.

MARTINS, P. F.; ITO, V. M.; BATISTELLA, C. B.; MACIEL, M. R. W. Free fatty acid separation from vegetable oil deodorizer distillate using molecular distillation process. Separation and Purification Technology. v. 46, n. 1, p. 78-84, 2006.

MBA, O. I.; DUMONT, M.-J.; NGADI, M. Palm Oil: Processing, Characterization and Utilization in the Food Industry - A Review. Food Bioscience, v. 10, p. 26-41, 2015.

NAGENDRA PRASAD, M. N.; SANJAY, K. R.; SHRAVYA KHATOKAR, M.; VISMAYA, M. N.; NANJUNDA SWAMY, S. Health benefits of Rice Bran - A Review. Journal of Nutrition \& Food Sciente, v. 3, 2011.

NAVARRO, S. L. B. Extração alcoólica de óleos de gérmen de milho e de torta de macadâmia e aproveitamento do material desengordurado na produção de concentrado proteico. 2016. Tese (Doutorado em Ciências da Engenharia de Alimentos) - Faculdade de Zootecnia e Engenharia de Alimentos, Universidade de São Paulo, Pirassununga, 2016.

NAVARRO, S. L. B.; CAPELLINI, M. C.; ARACAVA, K. K.; RODRIGUES, C. E. C. Food and Bioproducts Processing Corn germ-bran oils extracted with alcoholic solvents: Extraction yield, oil composition and evaluation of protein solubility of defatted meal. Food and Bioproducts Processing, v. 100, p. 185-194, 2016.

NEOH, B. K.; THANG, Y. M.; ZAIN, M. Z. M.; JUNAIDI, A. Palm pressed fibre oil: A new opportunity for premium hardstock? International Food Research Journal, v. 18, n. 2, p. 769-773, 2011.

OLIVEIRA, C. M.; GARAVAZO, B. R.; RODRIGUES, C. E. C. Liquid-liquid equilibria for systems composed of rice bran oil and alcohol-rich solvents: Application to extraction and deacidification of oil. Journal of Food Engineering, v. 110, n. 3, p. 418-427, $2012 \mathrm{a}$.

OLIVEIRA, R.; OLIVEIRA, V.; ARACAVA, K. K.; RODRIGUES, C. E. D. C. Effects of the extraction conditions on the yield and composition of rice bran oil extracted with 
ethanol-A response surface approach. Food and Bioproducts Processing, v. 90, n. 1, p. 22-31, 2012b.

OZEL, M. Z.; GOGUS, F. Subcritical Water as a Green Solvent for Plant Extraction. In: CHEMAT, F.; VIAN, M. A. Alternative Solvents for Natural Products Extraction. Berlin Heidelberg: Springer-Verlag, 2014. p. 73-89.

PALOZZA, P.; SESTITO, R.; PICCI, N.; LANZA P.; MONEGO G.; RANELLETTI, F.O. The sensitivity to beta-carotene growth-inhibitory and proapoptotic effects is regulated by caveolin-1 expression in human colon and prostate cancer cells. Carcinogenesis, v. 29, p. 2153-2161, 2008.

PAPANASTASIOU, G. E.; ZIOGAS I. I. Physical Behavior of Some Reaction Media. Density, Viscosity, Dielectric Constant, and Refractive Index Changes of EthanolCyclohexane Mixtures at Several Temperatures. Journal of Chemical e Enginnering Data. v. 36, p. 46-51, 1991.

PEREIRO, A. B.; ARAUJO, J. M. M.; ESPERANÇA, J. M. S. S.; MARRUCHO, I. M.; REBELO, L. P. N. lonic liquids in separations of azeotropic systems - A review. Journal of Chemical Thermodynamics. v. 46, p. 2-28, 2012.

PORIM. Test method carotene content. MalaysiaPalm Oil Research Institute of Malaysia, 1990.

PRADO, J. M.; FORSTER-CARNEIRO, T.; ROSTAGNO, M. A.; FOLLEGATTIROMERO, L. A.; MAUGERI FILHO, F.; MEIRELES, M. A. A. Obtaining sugars from coconut husk, defatted grape seed, and pressed palm fiber by hydrolysis with subcritical water. Journal of Supercritical Fluids, v. 89, p. 89-98, 2014.

PRAUSNITZ, J. M.; LICHTENTHALER, R. N.; DE AZEVEDO, E. G. Molecular thermodynamics of fluid-phase equilibria. 3th ed. New Jersey: Prentice Hall, 1999. $860 \mathrm{p}$.

PRZYBYLSKI, R.; MAG, T.; ESKIN, N. A. M.; MCDONALD, B. E. Canola Oil. 6 th ed. In: F. Shahidi. Bailey's Industrial Oil and Fat Products. New Jersey: John Wiley and Sons, 2005, v.2, p. 70.

QUEIROZ, S. C. N.; COLLINS, C. H.; JARDIM, I. C. S. F. Métodos de extração e/ou concentração de compostos encontrados em fluidos biológicos para posterior determinação cromatográfica. Química nova, vol. 24, n. 1, p. 68-76, 2001. 
RAHMALIA, W.; FABRE, J.; MOULOUNGUI, Z. Effects of Cyclohexane / Acetone Ratio on Bixin Extraction Yield by Accelerated Solvent Extraction Method. Procedia Chemistry, v. 14, p. 455-464, 2015.

REGITANO-D'ARCE, M. A. B. Ensaios de extração de óleo de girassol (Helianthus annus L.) com álcool etílico. 1985. 110f. Dissertação (Mestrado). Escola Superior de Agricultura "Luiz de Queiroz", Universidade de São Paulo, Piracicaba, 1985.

REGITANO-D'ARCE, M. A. B.; ASSIS, R. P.; LIMA, U. A. Functional Properties of Sunflower seed meal obtained by ethanol extraction. Archivos Latinoamericanos de Nutricion, v. 44, p. 29-32, 1994.

RIBEIRO, E.P.; SERAVALLI, E.A.G. Química de alimentos. São Paulo: Edgard Blucher, 2004, $184 \mathrm{p}$.

RITTNER, H. Extraction of vegetable oils with ethyl alcohol. Oleagineaux, v. 47, p. 2942, 1992.

RODRIGUES, C. E. C.; ARACAVA, K. K.; ABREU, F. N. Thermodynamic and statistical analysis of soybean oil extraction process using renewable solvent. International Journal of Food Science \& Technology, v. 45, n. 11, p. 2407-2414, 2010.

RODRIGUES, C. E. C.; OLIVEIRA, R. Response surface methodology applied to the analysis of rice bran oil extraction process with ethanol. International Journal of Food Science and Technology, v. 45, n. 4, p. 813-820, 2010.

RODRIGUEZ-AMAYA, D. B.; RODRIGUEZ, E. B.; AMAYA-FARFANL, J. Advances in Food Carotenoid Research: Chemical and Technological Aspects, Implications in Human Health. Malaysian Journal of Nutrition, v. 12, n. 1, p. 101-121, 2006.

SANAGI, M.M.; SEE, H.H.; IBRAHIM, W.A.W.; NAIM, A.A. Determination of carotene, tocopherols and tocotrienols in residue oil from palm pressed fiber using pressurized liquid extraction-normal phase liquid chromatography. Analytica Chimica Acta, p. 7176, 2005.

SANTOS, M. F. G.; ALVES, R. E.; ROCA, M. Carotenoid composition in oils obtained from palm fruits from the Brazilian Amazon. Grasas Y Aceites. v. 66, n. 3, p. 1-8, 2015.

SAWADA, M. M. Estudo da viabilidade técnica da substituição do hexano por etanol no processo de extração de óleo de soja: cinética da extração e índices de qualidade. 2012. 128f. Dissertação (Mestrado). Faculdade de Zootecnia e Engenharia de Alimentos, Universidade de São Paulo, Pirassununga, 2012. 
SAWADA, M. M.; VENÂNCIO, L. L.; TODA, T. A.; RODRIGUES, C. E. C. Effects of different alcoholic extraction conditions on soybean oil yield, fatty acid composition and protein solubility of defatted meal. Food Research International, Barking, v. 62, p. 662-670, 2014.

SCHARLACK, N. K. Efeito do tipo e grau de hidratação de solventes alcoólicos na extração simultânea de óleo e de ácidos clorogênicos de torta de sementes de girassol. 2015. 126f. Dissertação (Mestrado). Faculdade de Zootecnia e Engenharia de Alimentos, Universidade de São Paulo, Pirassununga, 2015.

SCHARLACK, N. K.; ARACAVA, K. K.; RODRIGUES, C. E. C. Effect of the type and level of hydration of alcoholic solvents on the simultaneous extraction of oil and chlorogenic acids from sunflower seed press cake. Journal of the Science of Food and Agriculture, 2017.

SCHIEBER, A.; CARLE, R. Occurrence of carotenoid cis-isomers in food: technological, analytical, and nutritional implications. Trends in Food Science \& Technology, v. 16, n. 9, p. 416-422, 2005.

SHAHIDI, F.; ZHONG, Y. Antioxidants: Regulatory Status. In: F. Shahidi. 6th ed. Bailey's Industrial Oil and Fat Products. New Jersey: John Wiley and Sons, p. 99189, 2005.

SILVA, S. M.; SAMPAIO, K. A.; TAHAM, T.; ROCCO, S. A.; CERIANI, R.; MEIRELES, A. J. A. Characterization of Oil Extracted from Buriti Fruit (Mauritiaflexuosa) Grown in the Brazilian Amazon Region. Journal of the American Oil Chemists' Society, v. 86, p. 611-616, 2009.

SLATTERY, M. L.; BENSON, J.; CURTIN, K.; MA, K. N.; SCHAEFFER, D.; POTTER, J. D. Carotenoids and colon cancer. American Journal of Clinical Nutrition, v. 71, p. 575-582, 2000.

TAN, Y. A.; SAMBANTHAMURTHI, R.; SUNDRAM, K.; WAHID, M. B. Valorisation of palm by-products as functional components. European Journal of Lipid Science and Technology, v. 109, n. 4, p. 380-393, 2007.

TAUNGBODHITHAM, A. K.; JONES, G. P.; WAHLQVISTC, M. L.; BRIGGS, D. R. Evaluation of extraction method for the analysis of carotenoids in fruits and vegetables. Food chemistry. v. 63, n. 4, p. 577-584, 1998. 
TERIGAR, B. G.; BALASUBRAMANIAN, S.; SABLIOV, C. M.; LIMA, M.; BOLDOR, D. Soybean and rice bran oil extraction in a continuous microwave system: From laboratory- to pilot-scale. Journal of Food Engineering, v. 104, n. 2, p. 208-217, 2011.

TIR, R.; DUTTA, P. C.; BADJAH-HADJ-AHMED, A. Y. Effect of the extraction solvent polarity on the sesame seeds oil composition. European Journal of Lipid Science and Technology, v.114, p. 1427-1438, 2012.

THOMAS, G. C. Análise Teórico-Experimental da Extração de Óleo de Soja em Instalação Industrial do Tipo Rotocell. 2003. 125 f. Tese (Doutorado). Programa de Pós-graduação em Engenharia Mecânica, Universidade Federal do Rio Grande do Sul, Porto Alegre, 2003.

TODA, T. A. Minimização de resíduos do processamento do café solúvel através do reaproveitamento da borra para extração de óleo utilizando solvente renovável. 2016. Dissertação (Mestrado em Ciências da Engenharia de Alimentos) Faculdade de Zootecnia e Engenharia de Alimentos, Universidade de São Paulo, Pirassununga, 2016.

TODA, T. A.; SAWADA, M. M.; RODRIGUES, C. E. C. Kinetics of soybean oil extraction using ethanol as solvent: Experimental data and modeling. Food and Bioproducts Processing, v. 98, p. 1-10, 2016.

TRESZCZANOWICZ, T.; KASPRZYCKA-GUTTMAN, T.; TRESZCZANOWICZ, A.J. Solubility of $\beta$-Carotene in Binary Solvents Formed by Some Hydrocarbons with Cyclohexanone and 1-Octanol. Journal of Chemical \& Engineering Data, v. 46, n.6, p. 1494-1496, 2001.

USDA. United States Department of Agriculture. Foreign Agricultural Service. Oilseeds: World Markets and Trade. 2016. Disponível em: <https://apps.fas.usda.gov/psdonline/circulars/oilseeds.pdf>. Acesso em: 20 Out. 2017.

WAKELYN, P. J.; WAN, P. J. Solvent extraction to obtain edible oil products. In: C. C: Akoh (editor), Handbook of functional Lipids, p. 89-131. Boca Raton: CRC Press, 2006.

WAN, P. J.; PAKARINEN, D. R.; HRON, R. J.; RICHARD, O. L.; CONKERTON, E. J. Alternative Hydrocarbon Solvents for Cottonseed Extraction. Journal of the American Oil Chemists' Society, v. 72, n. 6, 1995a. 
WAN, P. J.; HRON, R. J.; DOWD, M. K.; KUK, M. S.; CONKERTON, E. J. Alternative Hydrocarbon Solvents for Cottonseed Extraction: Plant Trials. Journal of the American Oil Chemists' Society, v. 72, n. 6, p. 1-4, 1995b.

WEL. I.; ROWLEY. R. L. Binary Liquid Mixture Viscosities and Densities. Journal of Chemical and Engineering Data. v. 29, p. 332-335, 1984.

WILLIAMS, M. A. Recovery of oils and fats from oilseeds and fatty materials. In: F. Shahidi. 6th ed. Bailey's Industrial Oil and Fat Products. New Jersey: John Wiley and Sons, p. 99-189, 2005.

WLSNIAK, J.; HILLET, J.; KATZ, O. Holdup and Extraction Characteristics of Jojoba Meal. Journal of the American Oil Chemists' Society, v. 64, p.1352-1354, 1987.

WOHLFARTH, C. Section 6: Fluid Properties. Permittivity (Dielectric constant) of liquids. In: HAYNES, W. M. (Ed.). Handbook of Chemistry and physics, CRC Press, 2015.

ZENEBON, O.; PASCUET, N. S.; TIGLEA, P.- Instituto Adolfo Lutz (São Paulo). Métodos físico-químicos para análises de alimentos São Paulo: Instituto Adolfo Lutz, p. 148-154, 2008.

ZHANG, F.; RHEE, K.C.; KOSEOGLU, S. S. Isopropyl alcoholextraction of cottonseed collets: efficiency and performance. Journal of Food Lipids, n. 9, p. 147-160, 2002. 


\section{ANEXO A}

Valores dos coeficientes determinados por Wohlfarth (2015) para diferentes solventes utilizados no cálculo da constante dielétrica (Di).

Tabela AN1 Coeficientes utilizados no cálculo da constante dielétrica (Di) para solventes puros.

\begin{tabular}{ccccc}
\hline \multirow{2}{*}{ Solvente } & \multicolumn{4}{c}{ Constantes } \\
\cline { 2 - 5 } & $\mathbf{A}$ & $\mathbf{B}\left(\mathbf{K}^{-1}\right)$ & $\mathbf{C ~ ( \mathbf { K } ^ { - 2 } )}$ & $\mathbf{D}\left(\mathbf{K}^{-3}\right)$ \\
\hline Etanol & 151,40 & $-0,8702$ & 0,001957 & $-0,0000016$ \\
Isopropanol & 104,16 & $-0,41011$ & 0,00042049 & \\
Hexano & 1,9768 & 0,00070933 & $-0,0000034$ & \\
Ciclohexano & 2,4293 & $-0,0012095$ & $-0,0000006$ & \\
Heptano & 2,474 & $-0,0022577$ & 0,0000012 &
\end{tabular}

Fonte: WOHLFARTH, C. Section 6: Fluid Properties. Permittivity (Dielectric constant) of liquids. In: HAYNES, W. M. (Ed.). Handbook of Chemistry and physics, CRC Press, 2015. 


\section{ANEXO B}

TABELA AN2 Temperaturas e composições de azeotropia para as misturas binárias de solventes.

\begin{tabular}{|c|c|c|c|c|}
\hline \multirow{3}{*}{ Mistura de solventes } & \multicolumn{3}{|c|}{ AZEOTROPIA } & \multirow{3}{*}{ REFERÊNCIAS } \\
\hline & \multirow{2}{*}{$\begin{array}{c}\text { Temperatura } \\
\left({ }^{\circ} \mathbf{C}\right)\end{array}$} & \multicolumn{2}{|c|}{ Fração mássica } & \\
\hline & & (1) & (2) & \\
\hline Hexano (1): Etanol (2) & 58,5 & 0,78 & 0,22 & GMEHLING et al., 2012 \\
\hline Hexano (1): Isopropanol (2) & 65 & 0,78 & 0,22 & GMEHLING et al., 2012 \\
\hline Ciclohexano (1): Etanol (2) & 64,9 & 0,70 & 0,30 & APTEL et al., 1976 \\
\hline Ciclohexano (1): Isopropanol (2) & 68,6 & 0,67 & 0,33 & APTEL et al., 1976 \\
\hline Heptano (1): Etanol (2) & 81,05 & 0,52 & 0,48 & PEREIRO et al., 2012 \\
\hline Heptano (1): Isopropanol (2) & 76,4 & 0,50 & 0,50 & GMEHLING et al., 2012 \\
\hline
\end{tabular}

Fonte: Própria autoria. 


\section{APÊNDICE A}

Na Tabela AP1 estão apresentados os valores dos PSH das misturas entre hexano e etanol e seus valores de Ra.

Tabela AP1 Valores dos PSH calculados para as misturas de solventes compreendidas por hexano e etanol.

Composição da mistura (em fração mássica)

\begin{tabular}{|c|c|c|c|c|c|c|}
\hline Etanol & Hexano & $\delta_{D}$ & $\delta_{P}$ & $\delta_{H}$ & $\delta_{\mathbf{T}}$ & Ra entre $\beta$-caroteno e mistura \\
\hline 0,00 & 1,00 & 14,90 & 0,00 & 0,00 & 14,90 & 5,3 \\
\hline 0,01 & 0,99 & 14,91 & 0,09 & 0,19 & 14,91 & 5,3 \\
\hline 0,02 & 0,98 & 14,92 & 0,18 & 0,39 & 14,92 & 5,2 \\
\hline 0,03 & 0,97 & 14,93 & 0,26 & 0,58 & 14,94 & 5,1 \\
\hline 0,04 & 0,96 & 14,94 & 0,35 & 0,78 & 14,96 & 5,0 \\
\hline 0,05 & 0,95 & 14,95 & 0,44 & 0,97 & 14,98 & 5,0 \\
\hline 0,06 & 0,94 & 14,95 & 0,53 & 1,16 & 15,01 & 4,9 \\
\hline 0,07 & 0,93 & 14,96 & 0,62 & 1,36 & 15,04 & 4,9 \\
\hline 0,08 & 0,92 & 14,97 & 0,70 & 1,55 & 15,07 & 4,9 \\
\hline 0,09 & 0,91 & 14,98 & 0,79 & 1,75 & 15,10 & 4,8 \\
\hline 0,10 & 0,90 & 14,99 & 0,88 & 1,94 & 15,14 & 4,8 \\
\hline 0,11 & 0,89 & 15,00 & 0,97 & 2,13 & 15,18 & 4,8 \\
\hline 0,12 & 0,88 & 15,01 & 1,06 & 2,33 & 15,22 & 4,8 \\
\hline 0,13 & 0,87 & 15,02 & 1,14 & 2,52 & 15,27 & 4,8 \\
\hline 0,14 & 0,86 & 15,03 & 1,23 & 2,72 & 15,32 & 4,9 \\
\hline 0,15 & 0,85 & 15,04 & 1,32 & 2,91 & 15,37 & 4,9 \\
\hline 0,16 & 0,84 & 15,04 & 1,41 & 3,10 & 15,43 & 5,0 \\
\hline 0,17 & 0,83 & 15,05 & 1,50 & 3,30 & 15,48 & 5,0 \\
\hline 0,18 & 0,82 & 15,06 & 1,58 & 3,49 & 15,54 & 5,1 \\
\hline 0,19 & 0,81 & 15,07 & 1,67 & 3,69 & 15,61 & 5,1 \\
\hline 0,20 & 0,80 & 15,08 & 1,76 & 3,88 & 15,67 & 5,2 \\
\hline 0,21 & 0,79 & 15,09 & 1,85 & 4,07 & 15,74 & 5,3 \\
\hline 0,22 & 0,78 & 15,10 & 1,94 & 4,27 & 15,81 & 5,4 \\
\hline 0,23 & 0,77 & 15,11 & 2,02 & 4,46 & 15,88 & 5,5 \\
\hline
\end{tabular}

\section{Parâmetros de Solubilidade de Hansen (PSH) da mistura}

Fonte: Própria autoria. 
O cálculo dos PSH para as misturas entre hexano e etanol iniciou-se com o acréscimo da menor fração mássica de etanol, cerca de 0,01, e posterior cálculo da Ra, neste caso obtendo 5,3. Em seguida, foram adicionadas frações mássicas crescentes de etanol resultando no decréscimo do valor de Ra até a concentração de etanol em torno de 0,15 que resultou em $\mathrm{Ra}$ igual a 4,9. A partir deste ponto, o acréscimo de etanol resultou em leve aumento de Ra, com destaque para o valor de 5,3. Este valor de Ra, para a mistura compreendida por hexano e etanol, é igual ao valor da $\mathrm{Ra}$ entre $\beta$-caroteno e hexano puro. Como os solventes hidrocarbonetos apresentam os menores valores de Ra e, consequentemente, apresentam maior capacidade em solubilizar o $\beta$-caroteno, as misturas que apresentaram $\mathrm{Ra}$ iguais ao Ra entre $\beta$-caroteno e solvente hidrocarboneto puro foram as misturas escolhidas para os experimentos de extração sólido-líquido. Dessa forma, no caso de hexano e etanol, sua composição em fração mássica foi de 0,79 e 0,21 respectivamente, como pode ser observado na Tabela AP1. 


\section{APÊNDICE B}

Curvas de calibração das soluções dos padrões de $\beta$-caroteno, $\alpha$-caroteno e licopeno em acetonitrila, analisados em UPLC/MS.

Figura B1 Curva da calibração para $\beta$-caroteno em UPLC/MS.

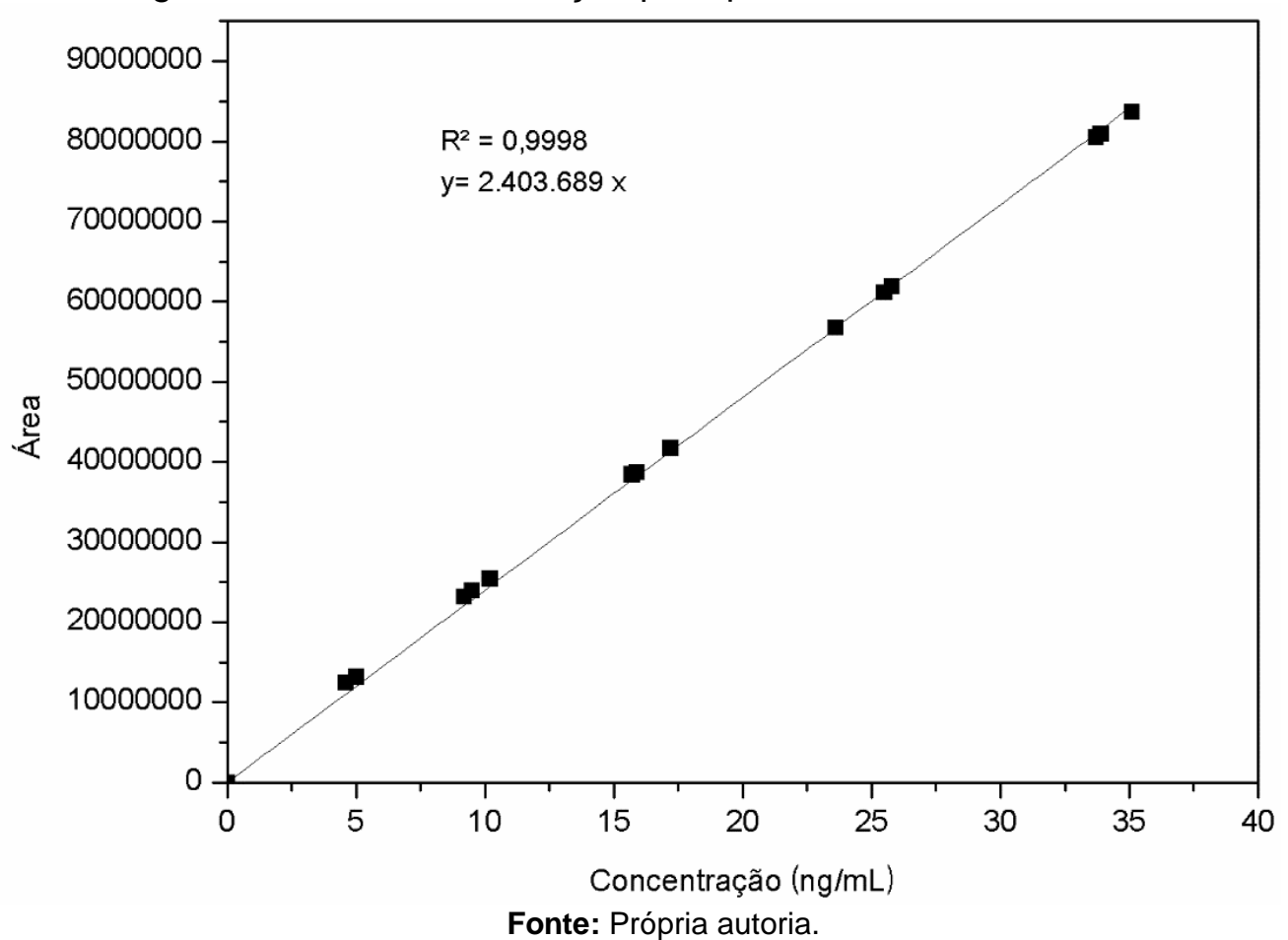


Figura B2 Curva da calibração para $\alpha$-caroteno em UPLC/MS.

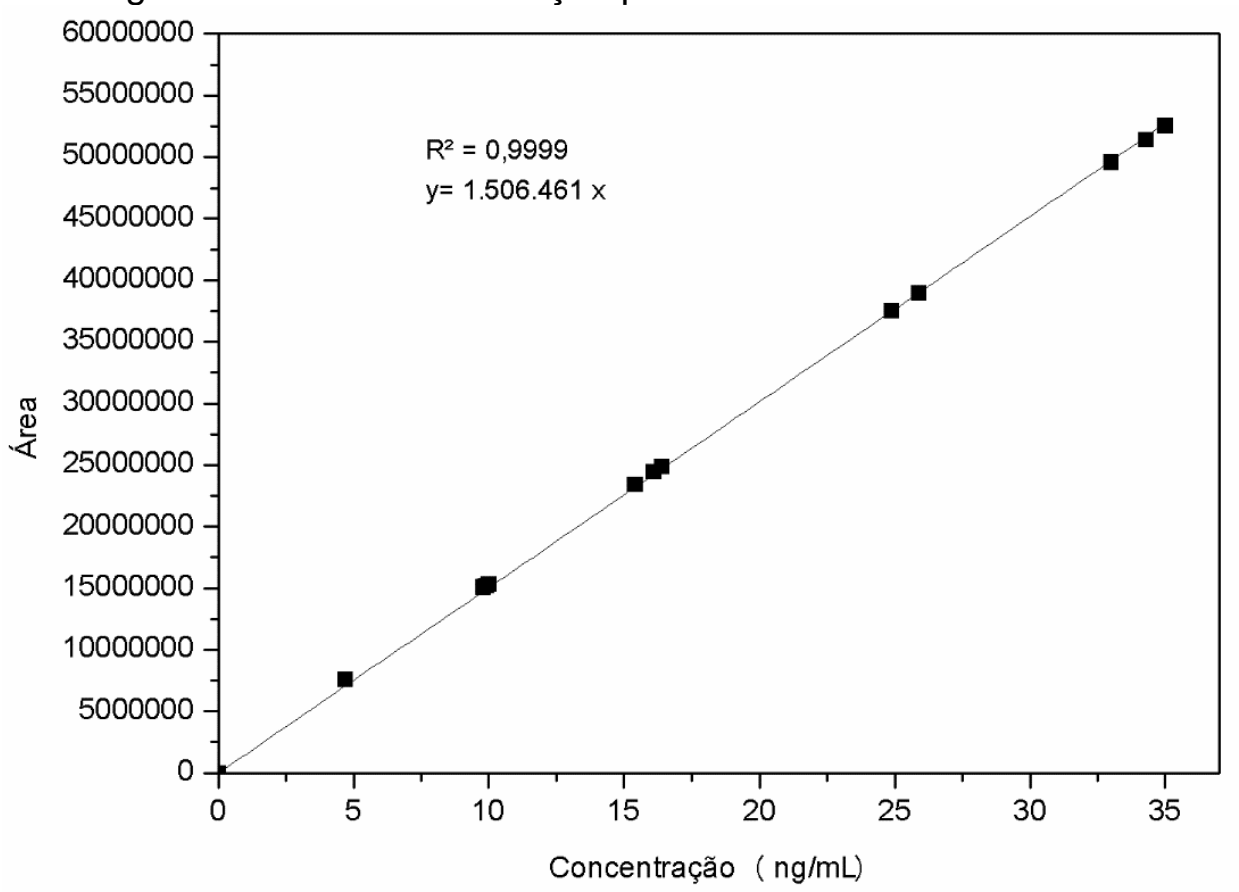

Fonte: Própria autoria.

Figura B3 Curva da calibração para licopeno em UPLC/MS.

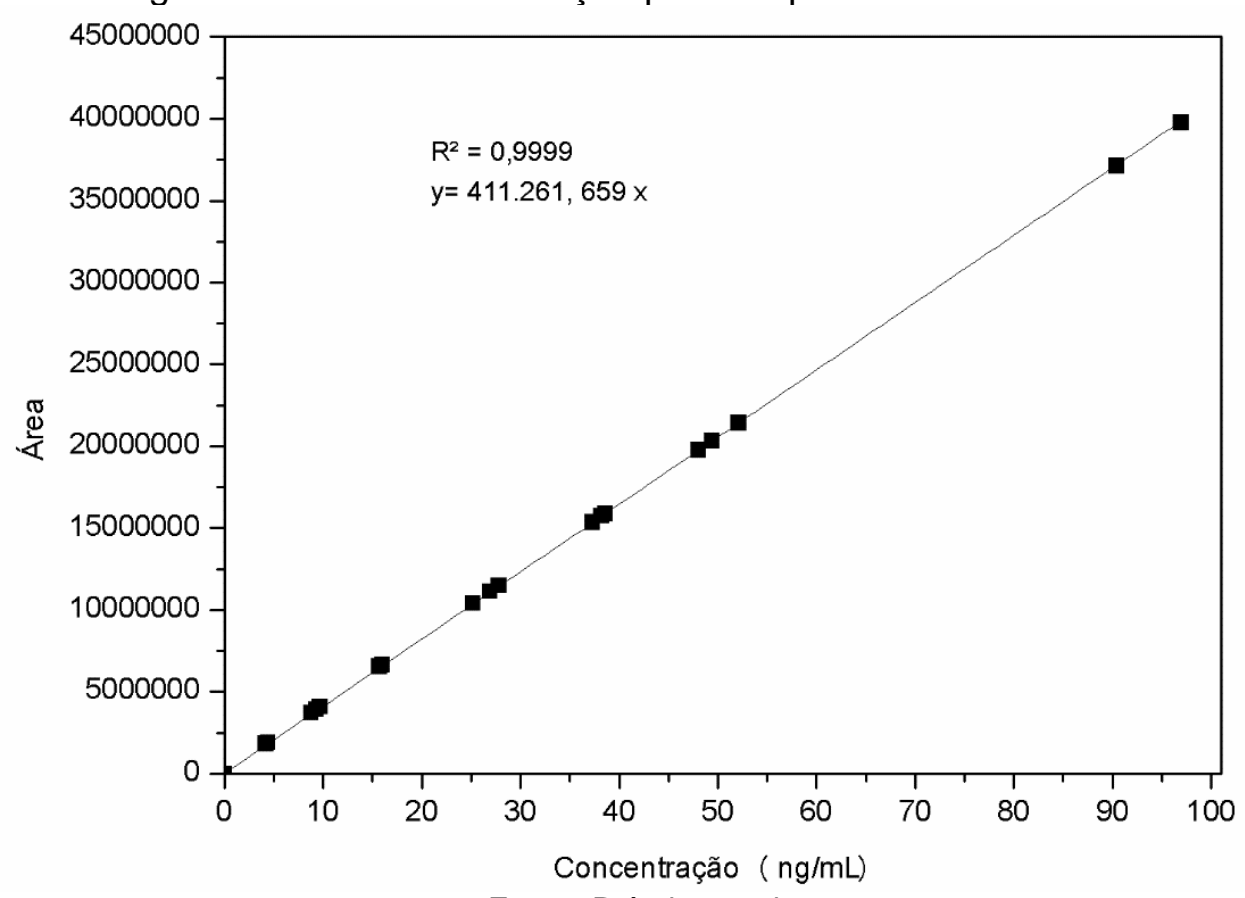

Fonte: Própria autoria. 


\section{APÊNDICE C}

Figura C1 Ajustes lineares para extrapolação de dados de viscosidade dinâmica (mPa.s) em um intervalo pequeno de temperatura para sistemas compreendidos por hexano e etanol (a); hexano e isopropanol (b); ciclohexano e etanol (c); ciclohexano e isopropanol (d); heptano e etanol (e); heptano e isopropanol (f), e suas respectivas misturas.

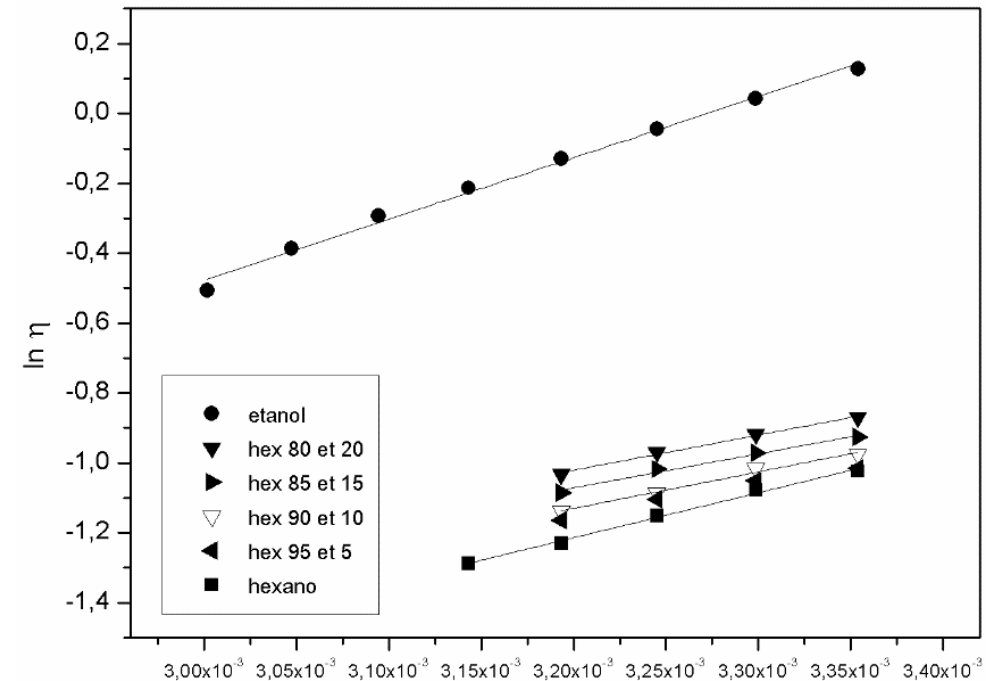

$1 / \mathrm{T}$

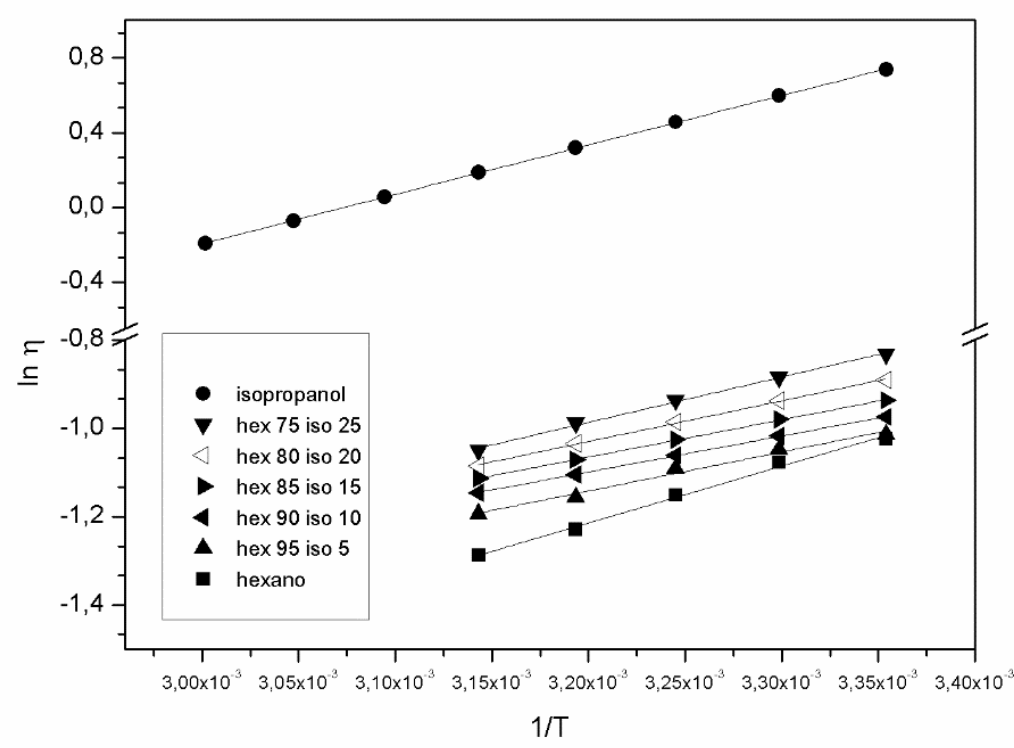

Fonte: Própria autoria. 


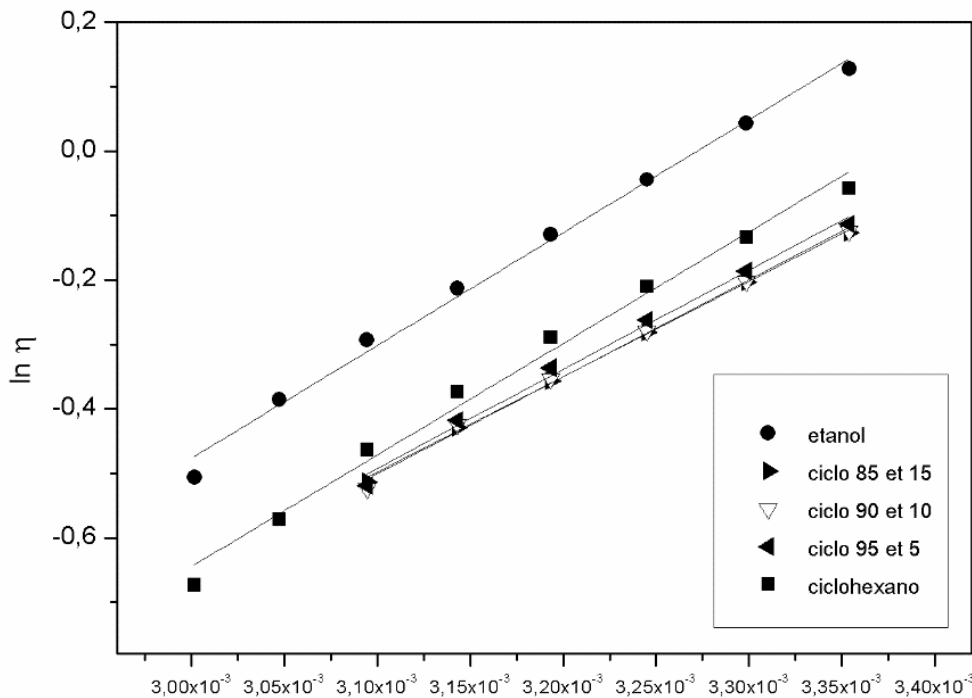

$1 / \mathrm{T}$

Fonte: Própria autoria.

(c)

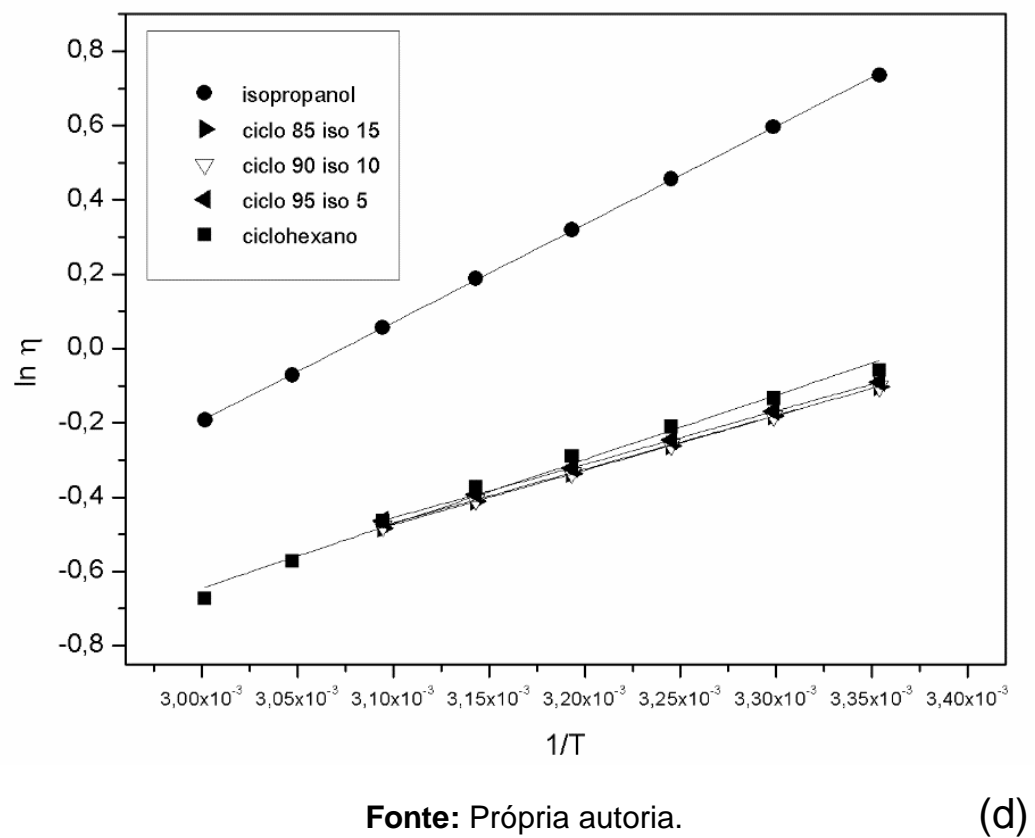

(d) 


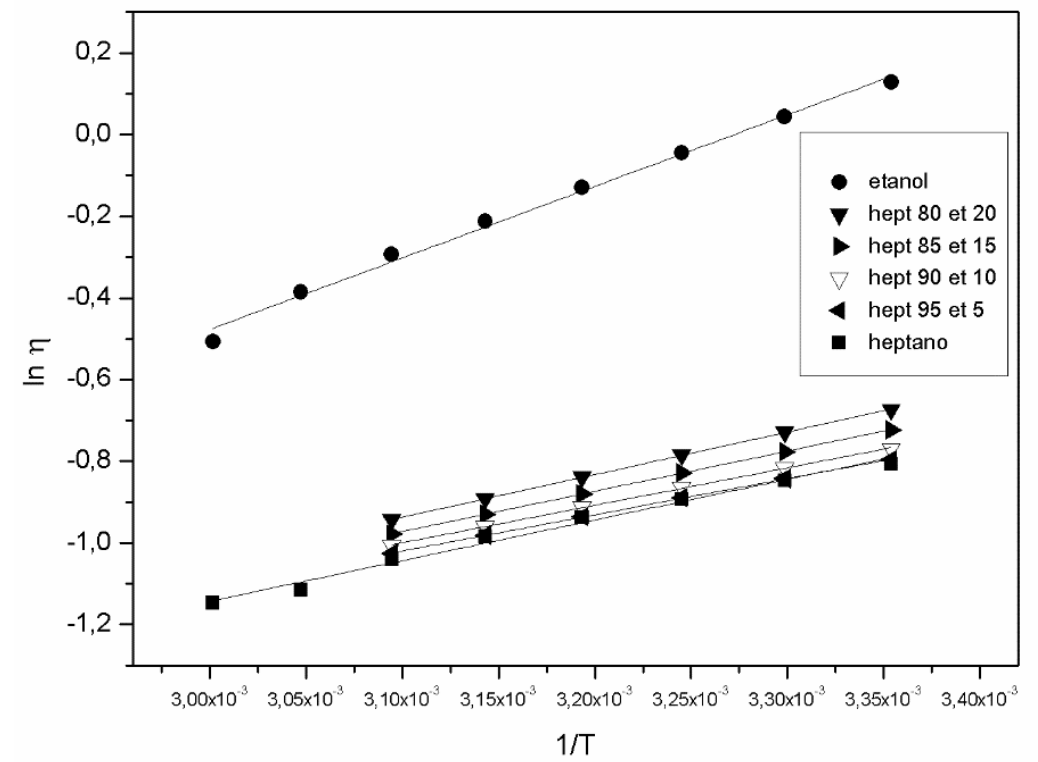

Fonte: Própria autoria. (e)

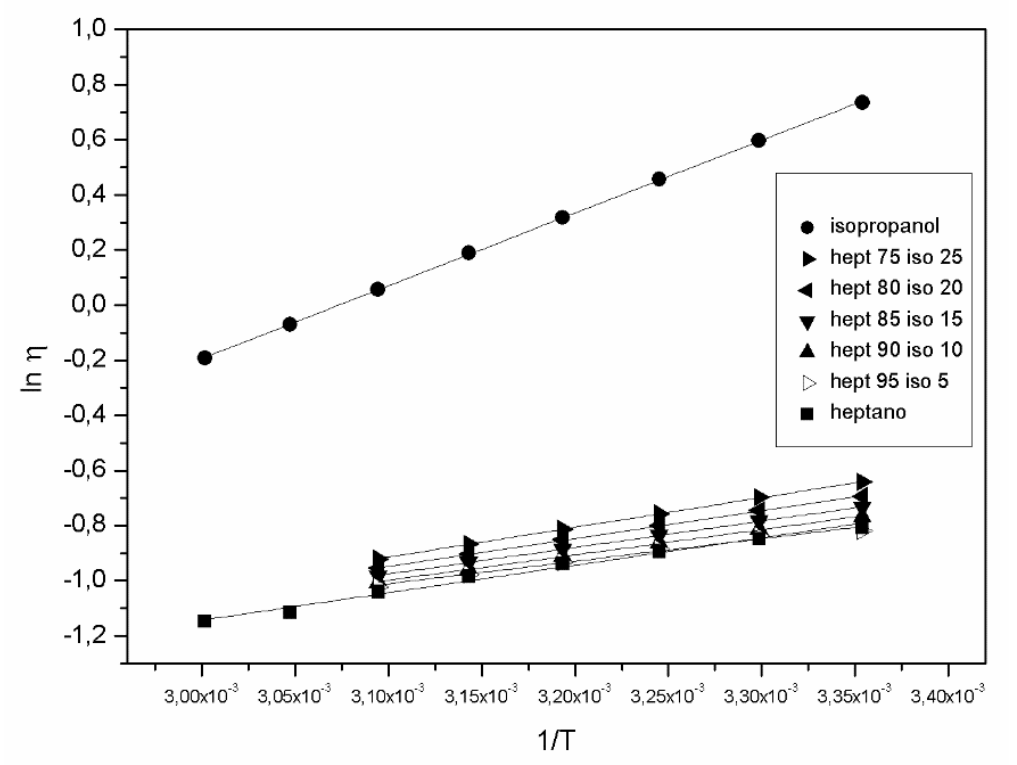

Fonte: Própria autoria.

(f) 


\section{APÊNDICE D}

Tabela D1 Valores obtidos para a regressão linear dos dados experimentais de viscosidade dinâmica (mPa.s) para diferentes solventes e misturas de solventes e cálculo do desvio (\%) entre os valores de viscosidade dinâmica experimentais e os calculados pela regressão linear.

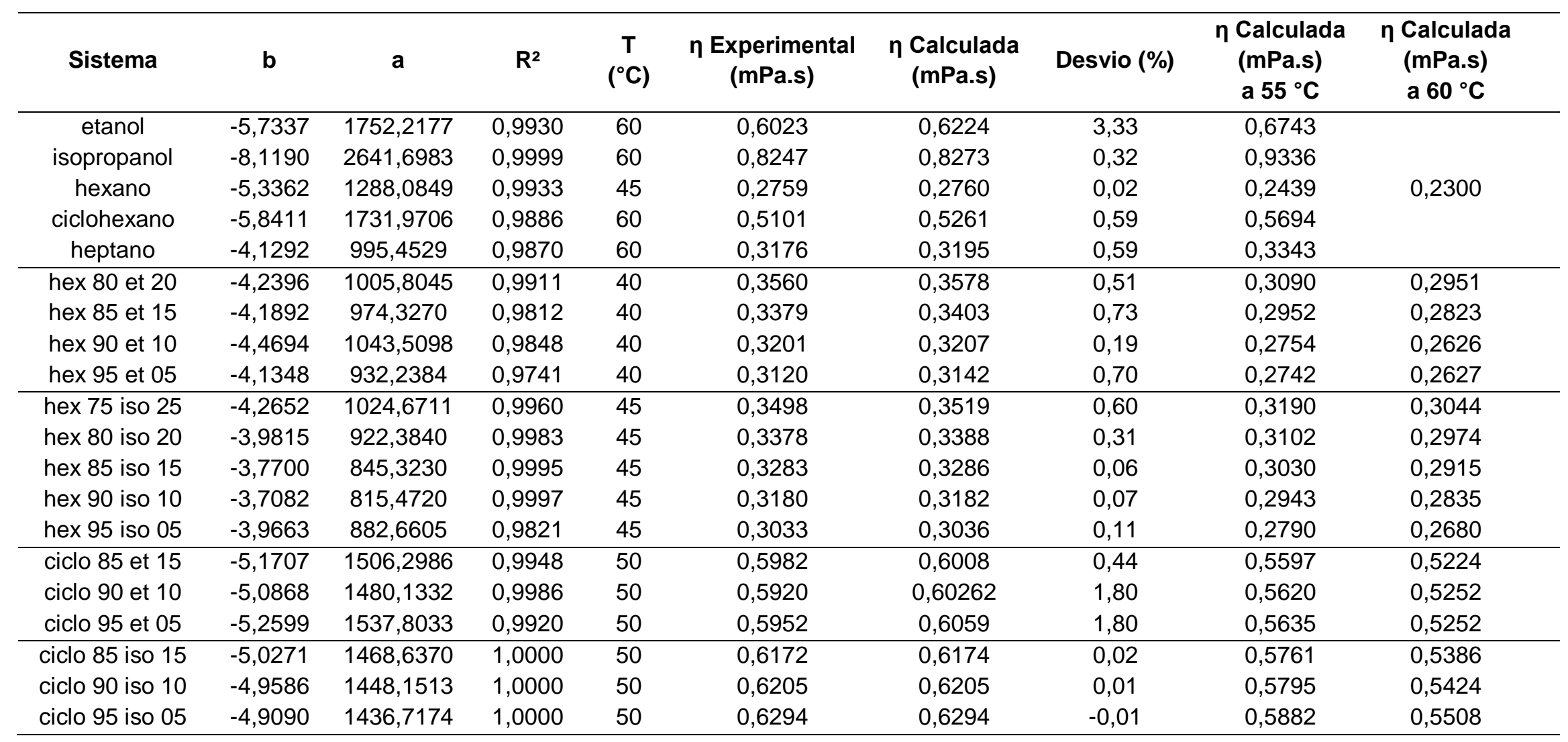




\begin{tabular}{|c|c|c|c|c|c|c|c|c|c|}
\hline & & & & & & & & \multicolumn{2}{|c|}{ (continuação) } \\
\hline hept 90 et 10 & $-3,8443$ & 917,6761 & 0,9993 & 50 & 0,3655 & 0,3662 & 0,20 & 0,3507 & 0,3363 \\
\hline hept 75 iso 25 & $-4,2574$ & 1078,5691 & 0,9998 & 50 & 0,3982 & 0,3986 & 0,11 & 0,3789 & 0,3606 \\
\hline hept 80 iso 20 & $-4,0785$ & 1010,1008 & 0,9997 & 50 & 0,3850 & 0,3857 & 0,17 & 0,3677 & 0,3511 \\
\hline hept 85 iso 15 & $-3,9489$ & 959,3126 & 0,9997 & 50 & 0,3747 & 0,3752 & 0,15 & 0,3586 & 0,3432 \\
\hline hept 90 iso 10 & $-3,8436$ & 917,9589 & 0,9993 & 50 & 0,3660 & 0,3668 & 0,21 & 0,3513 & 0,3368 \\
\hline
\end{tabular}

"Equação do tipo: $\ln \eta=\mathrm{a} .(1 / \mathrm{T})+\mathrm{b}$

Fonte: Própria autoria. 


\section{APÊNDICE E}

Figura E1 Ajustes lineares para extrapolação dados de massa específica $\left(\mathrm{g} / \mathrm{cm}^{3}\right)$ em um intervalo pequeno de temperatura para sistemas compreendidos por hexano e etanol (a); hexano e isopropanol (b); ciclohexano e etanol (c); ciclohexano e isopropanol (d); heptano e etanol (e); heptano e isopropanol (f), e suas respectivas misturas.

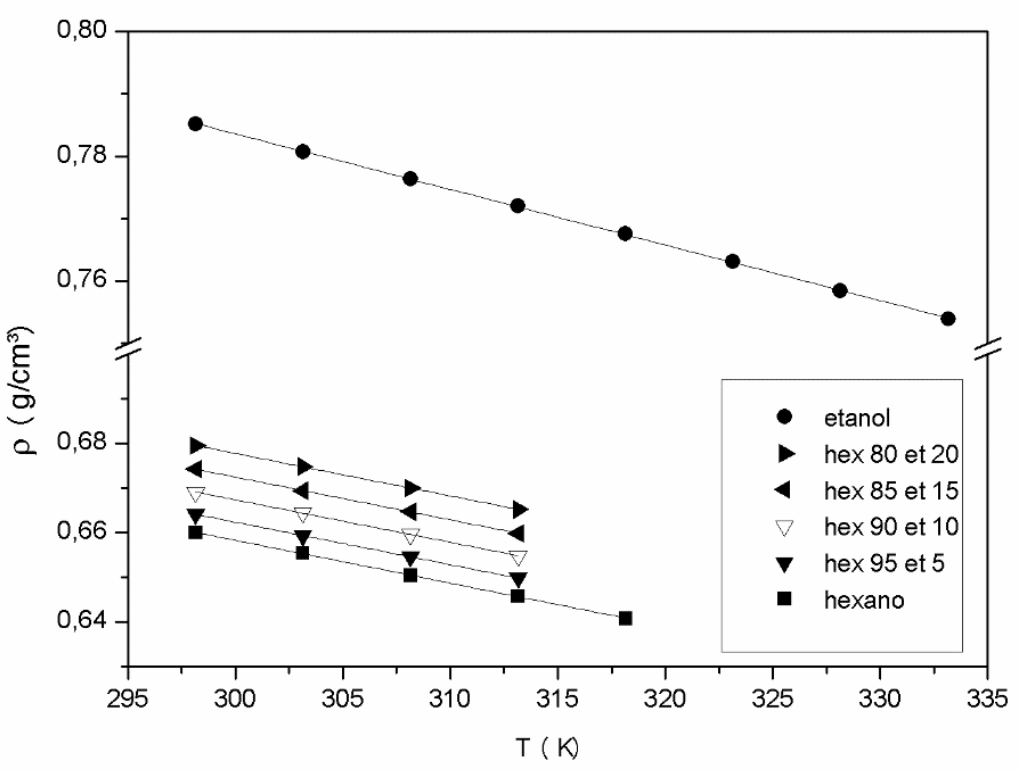

Fonte: Própria autoria.

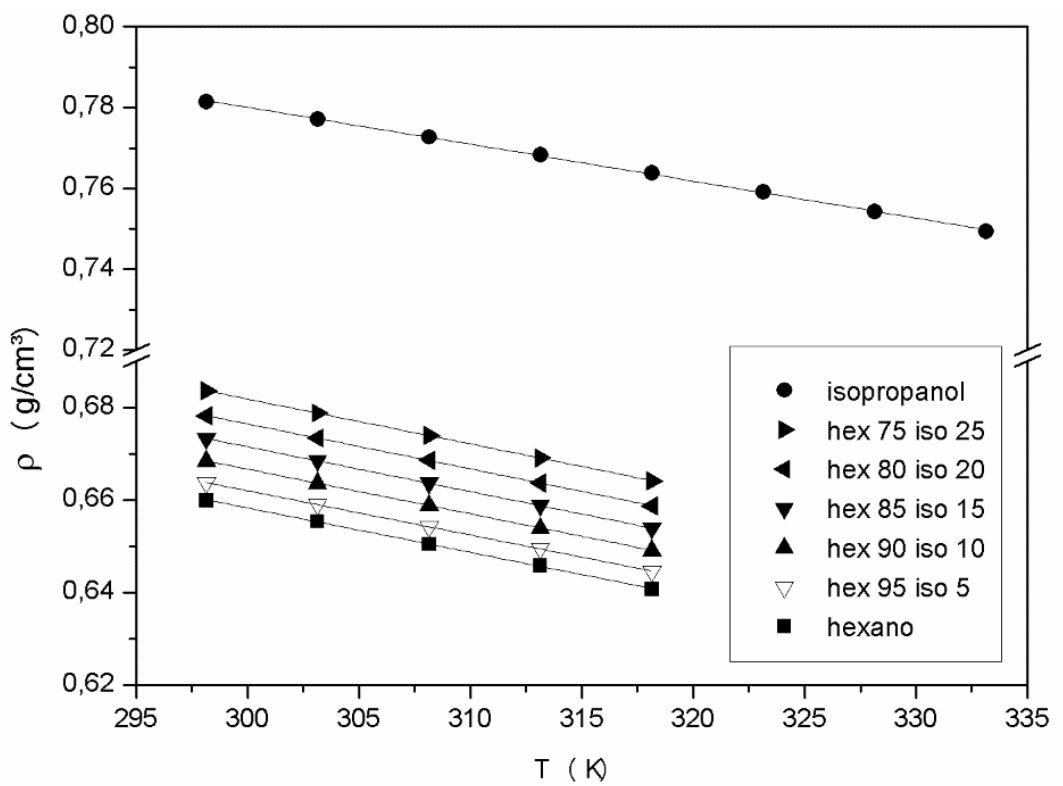

Fonte: Própria autoria. 


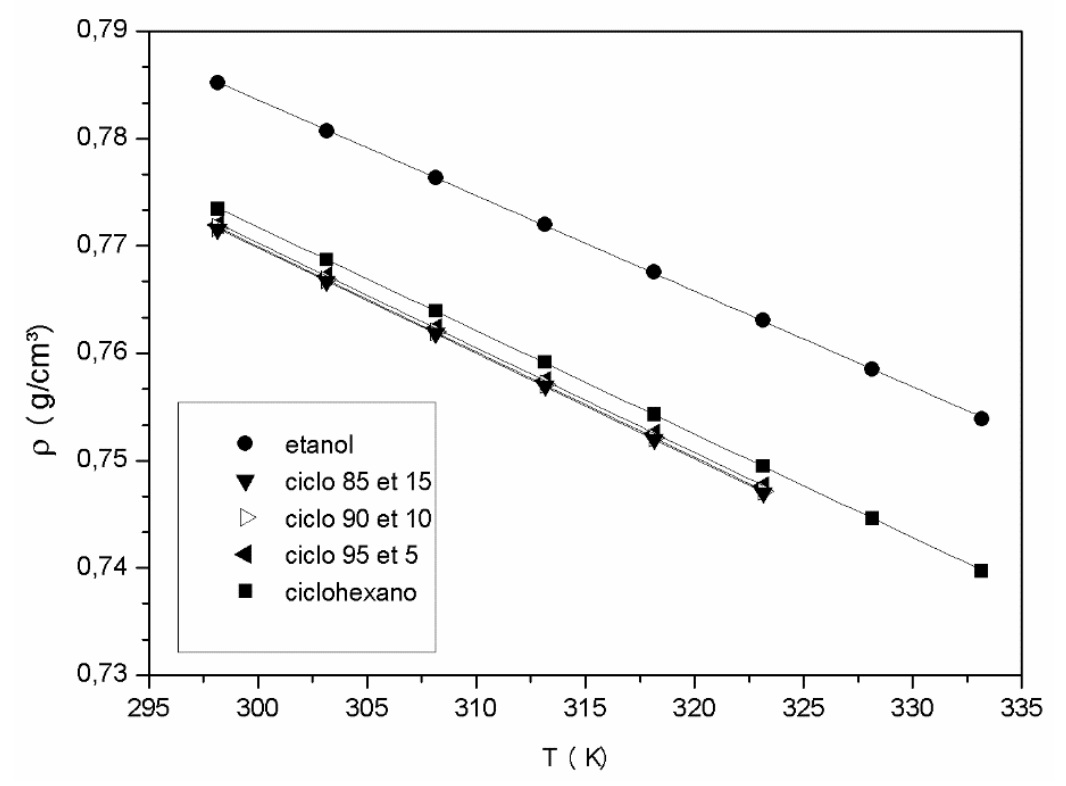

Fonte: Própria autoria.

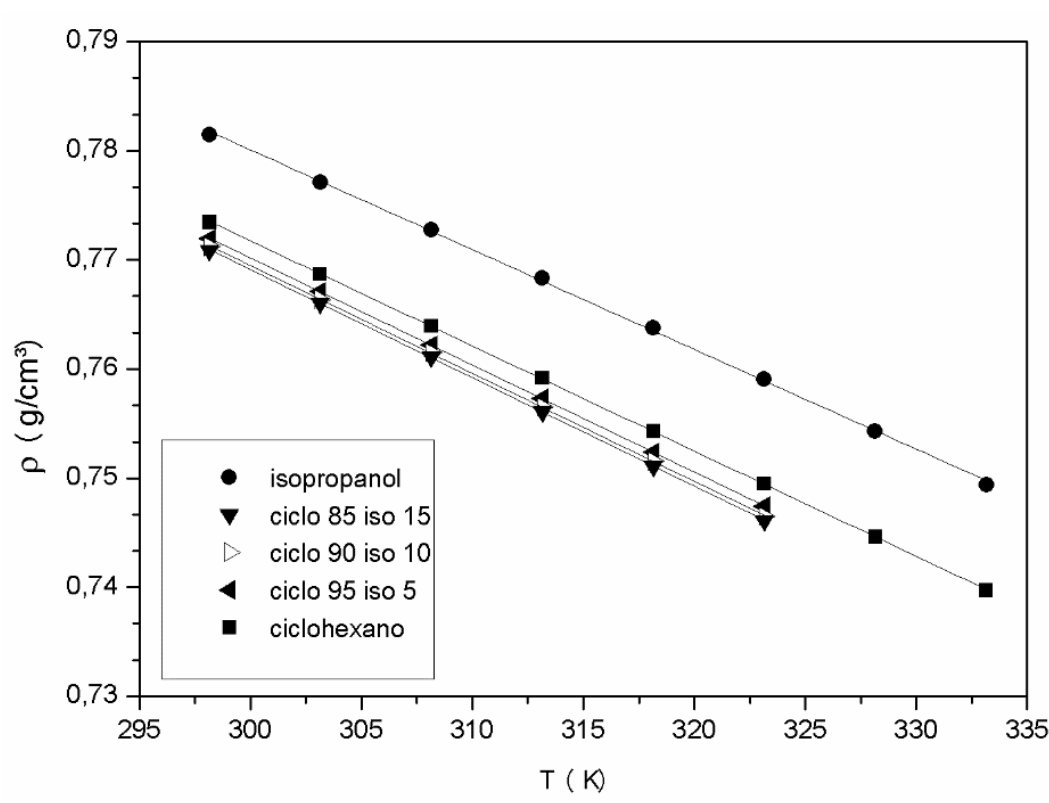

Fonte: Própria autoria. 


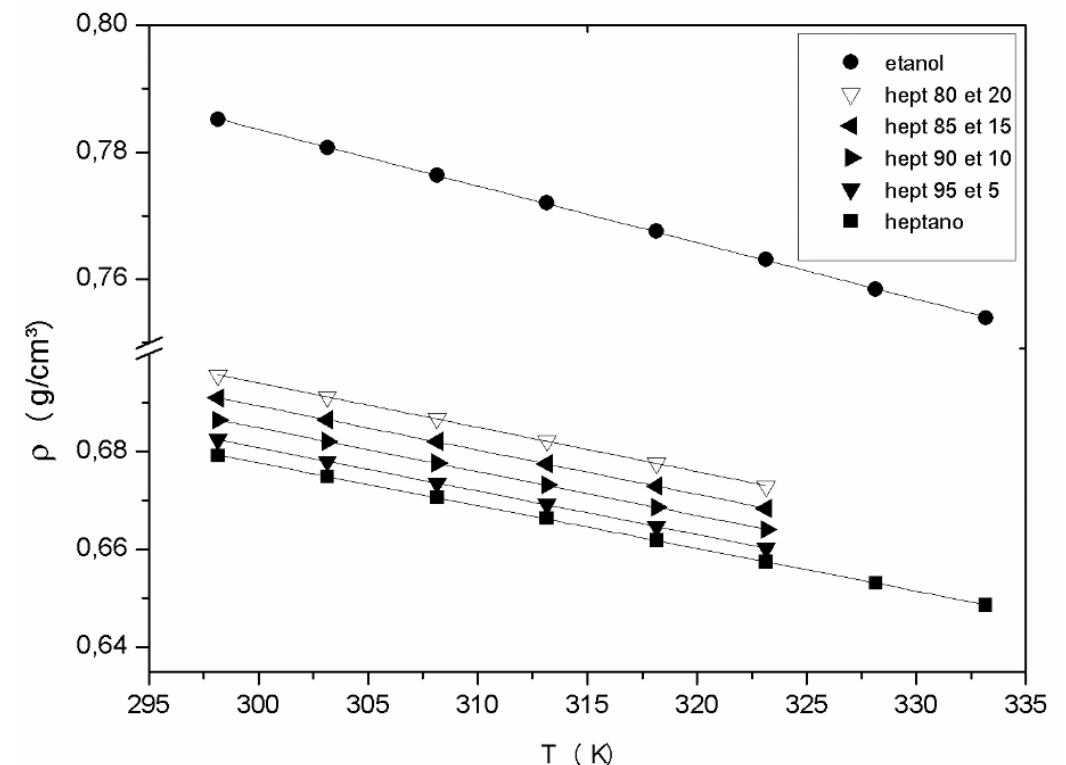

Fonte: Própria autoria.

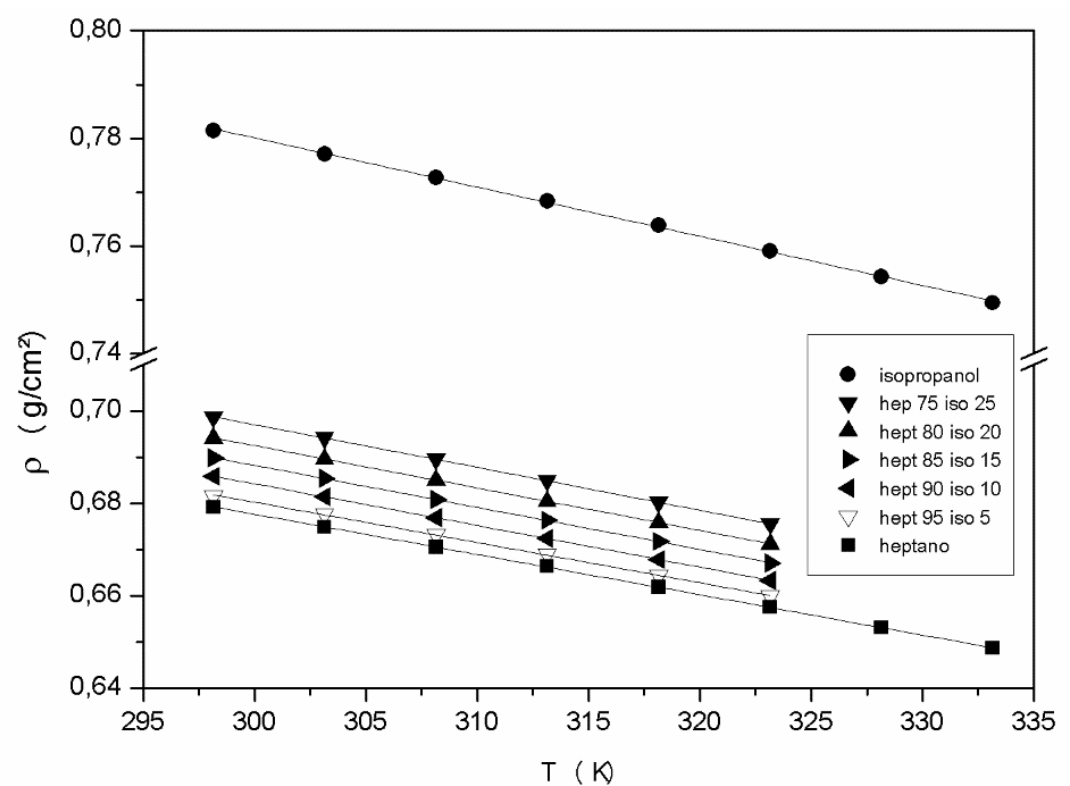

Fonte: Própria autoria.

(f) 


\section{APÊNDICE F}

Tabela F1 Valores obtidos para a regressão linear dos dados experimentais de massa específica $\left(\mathrm{g} / \mathrm{cm}^{3}\right)$ para diferentes solventes e misturas de solventes e cálculo do desvio (\%) entre os valores de massa específica experimentais e os calculados pela regressão linear.

\begin{tabular}{|c|c|c|c|c|c|c|c|c|c|}
\hline Sistema & $b^{*}$ & $a^{*}\left(10^{4}\right)$ & $\mathbf{R}^{2}$ & $\mathbf{T}\left({ }^{\circ} \mathrm{C}\right)$ & $\begin{array}{c}\rho \\
\text { Experimental } \\
\left(\mathrm{g} / \mathrm{cm}^{3}\right)\end{array}$ & $\begin{array}{c}\rho \\
\text { Calculada } \\
\left(\mathrm{g} / \mathrm{cm}^{3}\right)\end{array}$ & $\begin{array}{c}\text { Desvio } \\
(\%)\end{array}$ & $\begin{array}{c}\rho \text { Calculada } \\
\left(\mathrm{g} / \mathrm{cm}^{3}\right) \\
\text { a } 55^{\circ} \mathrm{C}\end{array}$ & $\begin{array}{c}\rho \text { Calculada } \\
\left(\mathrm{g} / \mathrm{cm}^{3}\right) \text { a } 60^{\circ} \mathrm{C}\end{array}$ \\
\hline etanol & 1,0508 & $-8,9079$ & 0,9999 & 60 & 0,7539 & 0,7540 & 0,02 & 0,7585 & \\
\hline isopropanol & 1,0544 & $-9,1428$ & 0,9994 & 60 & 0,7494 & 0,7498 & 0,05 & 0,7544 & \\
\hline hexano & 0,9465 & $-9,6067$ & 0,9996 & 45 & 0,6407 & 0,6409 & 0,02 & 0,6313 & 0,6265 \\
\hline ciclohexano & 1,06084 & $-9,6365$ & 0,9999 & 60 & 0,7397 & 0,7398 & 0,01 & 0,7446 & \\
\hline heptano & 0,9395 & $-8,7286$ & 0,9999 & 60 & 0,6486 & 0,6487 & 0,01 & 0,6531 & \\
\hline hex 80 et 20 & 0,9638 & $-9,5333$ & 0,9999 & 40 & 0,6652 & 0,6653 & 0,01 & 0,6510 & 0,6462 \\
\hline hex 85 et 15 & 0,9594 & $-9,5667$ & 0,9999 & 40 & 0,6598 & 0,6598 & 0,01 & 0,6455 & 0,6407 \\
\hline hex 90 et 10 & 0,9530 & $-9,5200$ & 0,9999 & 40 & 0,6548 & 0,6549 & 0,01 & 0,6406 & 0,6358 \\
\hline hex 95 et 05 & 0,9486 & $-9,5400$ & 0,9999 & 40 & 0,6498 & 0,6499 & 0,01 & 0,6355 & 0,6308 \\
\hline hex 75 iso 25 & 0,9732 & $-9,7133$ & 0,9999 & 45 & 0,6642 & 0,6642 & 0,01 & 0,6545 & 0,6496 \\
\hline hex 80 iso 20 & 0,9683 & $-9,7263$ & 0,9999 & 45 & 0,6587 & 0,6589 & 0,02 & 0,6491 & 0,6443 \\
\hline hex 85 iso 15 & 0,9623 & $-9,6933$ & 0,9999 & 45 & 0,6539 & 0,6539 & 0,01 & 0,6442 & 0,6394 \\
\hline hex 90 iso 10 & 0,9569 & $-9,6733$ & 0,9999 & 45 & 0,6491 & 0,6491 & 0,01 & 0,6395 & 0,6346 \\
\hline hex 95 iso 05 & 0,9496 & $-9,5867$ & 0,9999 & 45 & 0,6445 & 0,6446 & 0,01 & 0,6350 & 0,6302 \\
\hline ciclo 85 et 15 & 1,0644 & $-9,8191$ & 0,9999 & 50 & 0,7470 & 0,7471 & 0,01 & 0,7422 & 0,7373 \\
\hline ciclo 90 et 10 & 1,0644 & $-9,8152$ & 0,9999 & 50 & 0,7472 & 0,7472 & 0,01 & 0,7423 & 0,7374 \\
\hline ciclo 95 et 05 & 1,0631 & $-9,7619$ & 0,9999 & 50 & 0,7476 & 0,7476 & 0,01 & 0,7428 & 0,7379 \\
\hline ciclo 85 iso 15 & 1,0666 & $-9,9162$ & 0,9999 & 50 & 0,7461 & 0,7462 & 0,01 & 0,7412 & 0,7362 \\
\hline ciclo 90 iso 10 & 1,0663 & $-9,8933$ & 0,9999 & 50 & 0,7465 & 0,7466 & 0,01 & 0,7417 & 0,7367 \\
\hline ciclo 95 iso 05 & 1,0643 & $-9,8057$ & 0,9999 & 50 & 0,7474 & 0,7474 & 0,01 & 0,7425 & 0,7376 \\
\hline
\end{tabular}




\begin{tabular}{|c|c|c|c|c|c|c|c|c|c|}
\hline & & & & & & & & & (continuação) \\
\hline hept 80 et 20 & 0,9661 & $-9,0686$ & 0,9999 & 50 & 0,6730 & 0,6730 & 0,01 & 0,6685 & 0,6640 \\
\hline hept 85 et 15 & 0,9606 & $-9,0400$ & 0,9999 & 50 & 0,6684 & 0,6685 & 0,02 & 0,6640 & 0,6594 \\
\hline hept 90 et 10 & 0,9541 & $-8,9733$ & 0,9999 & 50 & 0,6640 & 0,6641 & 0,02 & 0,6596 & 0,6552 \\
\hline hept 95 et 05 & 0,9471 & $-8,8762$ & 0,9999 & 50 & 0,6602 & 0,6603 & 0,01 & 0,6558 & 0,6514 \\
\hline hept 75 iso 25 & 0,9752 & $-9,2724$ & 0,9999 & 50 & 0,6755 & 0,6756 & 0,01 & 0,6709 & 0,6663 \\
\hline hept 80 iso 20 & 0,9679 & $-9,1791$ & 0,9999 & 50 & 0,6712 & 0,6713 & 0,01 & 0,6667 & 0,6621 \\
\hline hept 85 iso 15 & 0,9614 & $-9,1067$ & 0,9999 & 50 & 0,6671 & 0,6671 & 0,01 & 0,6626 & 0,6580 \\
\hline hept 90 iso 10 & 0,9553 & $-9,0343$ & 0,9992 & 50 & 0,6633 & 0,6634 & 0,01 & 0,6588 & 0,6543 \\
\hline hept 95 iso 05 & 0,9419 & $-8,7219$ & 0,9999 & 50 & 0,6599 & 0,6601 & 0,03 & 0,6557 & 0,6513 \\
\hline
\end{tabular}

Equação do tipo: $\rho=a \cdot T+b$

Fonte: Própria autoria. 